\title{
DISTRIBUIÇÃO DE RENDA E MERCADO INTERNO NO BRASIL
}

\author{
JOSÉ EDUARDO NOGUEIRA CAMARGO NETTO \\ Economista
}

Orientador: Prof. Dr. RODOLFO HOFFMANN

Dissertação apresentada à Escola Superior de Agricultura "Luiz de Queiroz", da Universidade de São Paulo, para obtenção do título de Mestre em Ciência, Área de Concentração: Economia Aplicada.

\author{
PIR A CICABA \\ Estado de São Paulo - Brasil \\ Janeiro - 1997
}


Dados Internacionais de Catalogação na Publicação (CIP)

DIVISĀO DE BIBLIOTECA E DOCUMENTAÇĀO - Campus "Luiz de Queiroz"IUSP

Camargo Netto, José Eduardo Nogueira

Distribuiçåo de renda e mercado interno no Brasil / José Eduardo Nogueira Camargo Netto. - - Piracicaba, 1997.

$159 p$.

1997.

Dissertação (mestrado) - - Escola Superior de Agricultura Luiz de Queiroz,

Bibliografia.

1. Brasil 2. Distribuiçăo de renda 3. Macroeconomia 4. Mercado Interno I. Título 


\title{
DISTRIBUIÇÃO DE RENDA E MERCADO INTERNO NO BRASIL
}

\author{
JOSÉ EDUARDO NOGUEIRA CAMARGO NETTO
}

Aprovada em: $\quad$ 28.04.1997

Comissão Julgadora:

Prof. Dr. Rodolfo Hoffmann

Prof. Dr. Jorge Lobo Miglioli

Prof. Dr. César Roberto Leite da Silva
ESALQ/USP

UNESPIAraraquara

PUC/SP

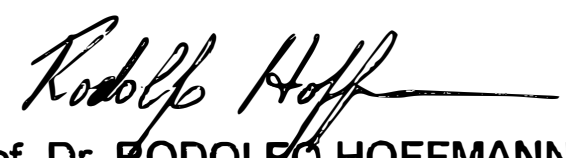

Prof. Dr. RODOLFO HOFFMANN Orientador 
Às minhas famílias, uma representada por mãe e irmãos, sem a qual não poderia ter chegado ao mestrado; outra, por esposa e filhos, que estiveram dando apoio $e$ estabilidade emocional. 


\title{
DISTRIBUIÇÃO DE RENDA E MERCADO INTERNO NO BRASIL
}

\author{
Autor: JOSÉ EDUARDO NOGUEIRA CAMARGO NETTO
}

Orientador: PROF. DR. RODOLFO HOFFMANN

\section{RESUMO}

O presente trabalho tem como proposta estudar as inter-relações entre distribuição de renda e mercado interno no Brasil. Para tal, optou-se por verificar qual seria o comportamento de variáveis macroeconômicas, especialmente inflação, consumo e investimento, caso seja implementada uma política de redistribuição de renda que beneficie os estratos mais pobres da população.

A fim de estudar esse tema central com maior profundidade e conhecimento, analisa-se a distribuição de renda nos seus aspectos funcional e pessoal. O primeiro é uma contribuição a esse tema que ainda é pouco explorado na literatura econômica nacional. A repartição da renda nacional entre lucros (incluindo outras rendas que não o salário) e salários no Brasil não é tão desfavorável aos salários como se tem veiculado em algumas publicações nos últimos anos. Embora em comparações internacionais ainda seja baixa essa participação, a explicação reside nas particularidades da economia brasileira, quais sejam alta proporção das atividades informais e maior peso da produção primária no produto total.

O enfoque pessoal resgata o comportamento da distribuição de renda no Pais desde 1960, a partir de quando se tem dados do IBGE sobre renda. Mostra-se que, a despeito das altas taxas de crescimento do produto entre 
1960 e 1980, a desigualdade cresceu insistentemente até 1990, apenas excetuando-se rápidos períodos dentro desse intervalo maior.

Relativamente à discussão das inter-relações entre distribuição de renda e mercado interno, está subjacente a proposta de retomada do crescimento sustentado através da redistribuição dos rendimentos em favor das camadas menos favorecidas da distribuição. O capítulo dedica parte ao desenvolvimento teórico do assunto, orientado pelas idéias do economista polonês Michal Kalecki. Através da utilização de um modelo baseado em oligopólios, chega-se ao resultado de que uma transferência de renda dos lucros para os salários provoca três desdobramentos principais: aumento do emprego, da produção e dos lucros totais. Outra discussão importante é o estudo do comportamento de variáveis políticas e sua relação com o crescimento e a distribuição de renda.

Finalizando, são estudadas três propostas de caráter redistributivo: reforma agrária, investimentos em educação e programas de renda mínima. Verifica-se que, caso haja o aporte prévio de recursos, não há restrições quanto ao comportamento da inflação. Em sintonia com o referencial teórico, estimular-se ia em maior proporção a produção de bens populares, sobre os quais recairia com maior força o aumento de demanda. 


\title{
INCOME DISTRIBUTION AND THE INTERNAL MARKET IN BRAZIL
}

\author{
Author: JOSÉ EDUARDO NOGUEIRA CAMARGO NETTO \\ Adviser: PROF. DR. RODOLFO HOFFMANN
}

\section{SUMMARY}

The objective of this Dissertation is to provide an analysis based on the interrelation between income distribution and the Brazilian domestic market. With such a view, an analysis will be conducted in order to understand the behavior of macroeconomic variables, specially inflation, consumption, and investiments, should an income redistribution policy be implemented, so as to bring benefit to the lower income segment of the population.

Seeking to thoroughly understand this central theme, the analysis on income distribution will be based on both functional and personal aspects. The first represents a contribution to this subject matter, which finds little background on economic literature in Brazil. The distribution of the national income between profits (including other income, except salary), and salaries in Brazil is not as unfavorable to salaries, as widely mentioned on certain publications in recent years. Such participation is rather low when compared to international standards. The reason relies on the peculiarities of the Brazilian economy, which includes a significant proportion of informal activities and a greater share of the primary sector on the total output.

The second (personal aspect) brings to analysis the behavior of income distribution in the country starting in 1960, since which data on income is available from IBGE. It is shown that, despite the high rates of growth on prodution in the period 1960-1980, the inequalities raised consistently until 1990 , with few short duration exceptions. 
With respect to the discussion on the interrelation between income distribution and the internal market, it should be noted that the underlying aspect is based on the return to sustained growth, through the redistribution of income to lower level income families. The chapter is partially dedicated to the theoretical development of the subject, based on the ideas of the Polish economist Michal Kalecki. Through the use of a model based on oligopolies, one comes to the conclusion that a transfer of income from profits to salaries results in three major consequences: (1) higher employment rate; (2) higher prodution; and (3) higher total profits. Another important issue is the analysis of the behavior of political variables andi its relationship to growth and income distribution.

In sum, it will analyzed three proposals with a redistribution nature: land reform, investments on education, and minimum wage programs. It was found that should there be a prior allocation of resources, there should be no restriction to changes in inflation. Based on a theoretical referential, production of basic goods could be further strengthened, and a stronger demand could be expected. 


\section{S U MÁRIO}

\section{Página}

RESUMO

iv

SUMMARY

vi

1. INTRODUÇÃO

1.1. A importância do tamanho do mercado $\quad$..................................... 3

1.2. A desejada retomada do desenvolvimento ................................... 4

2. A PARTICIPAÇÃO DOS SALÁRIOS NA RENDA NACIONAL $\quad$............... 8

2.1. O mercado de trabalho no Brasil $\quad$............................................... 11

2.1.1. O período 1940/1980 .................................................... 11

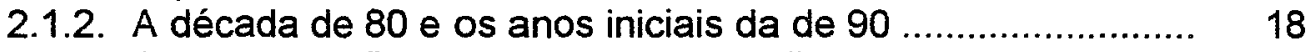

2.1.3. A segmentação do mercado de trabalho …....................... 24

2.2. Metodologia de mensuração: conceitos básicos _........................ $\quad 30$

2.3. Os avanços na mensuração da participação dos assalariados na renda

3. DISTRIBUIÇÃO DE RENDA NO BRASIL DESDE A DÉCADA DE $60 \quad \ldots . .46$

3.1. Industrialização no Brasil e Conformação do Mercado Interno $\quad$.... 51

3.2. A década de 60: consenso nos resultados e divergências nas interpretações

3.3. Anos 70: crescimento com desigualdade

3.4. A década de 80: aumento da desigualdade como uma das faces da crise.

3.5. O periodo 1960/1990: houve perdedores?

4. REDISTRIBUIÇÃO DA RENDA: UM DOS POSSIVEIS CAMINHOS ............. 90

4.1. A questão teórica

4.1.1. A refutação da "Lei de Say"

4.1.2. Aspectos políticos e sua relação com o crescimento e a distribuição de renda

4.1.3. Impactos de uma redistribuição de renda no modelo de Kalecki

4.1.3.1. A equação dos determinantes dos lucros

4.1.3.2. Distribuição de renda na determinação dos salários e da renda nacional

4.2. Algumas propostas redistributivistas

4.2.1. Investimentos em educação

4.2.1.1. Diagnóstico da situação presente

4.2.1.2. A importância da educação como determinante da qualificação do trabalhador

4.2.2. Os programas de renda mínima 
4.2.2.2. As alternativas de financiamento do PGRM

4.3. Possiveis impactos macroeconômicos decorrentes de uma redistribuição dos rendimentos

4.3.1. Os principais efeitos associados à especificidade de cada política

4.3.2. Os impactos macroeconômicos decorrentes das políticas adotadas, associaddos diretamente à redistribuição dos rendimentos

4.3.2.2. Consumo e investimento 


\section{INTRODUÇÃO}

Após a Segunda Guerra Mundial, as economias capitalistas do globo experimentaram praticamente três décadas de crescimento econômico acelerado. As nações desenvolvidas, num esforço de reconstrução apoiado por recursos americanos, reestruturaram suas economias, ao mesmo tempo que seus povos passaram a participar crescentemente dos benefícios do crescimento. A década de 50, em especial, é lembrada como aquela em que imperou o Estado do Bem-Estar (Welfare State) social naqueles países. Foi uma época de crucial importância para a consolidação de sociedades mais igualitárias no aspecto econômico-social, de maior repartição dos frutos do crescimento, processo este que possibilitou a estes países reforçarem sua condição de nações desenvolvidas.

Nos países "em desenvolvimento" do capitalismo moderno imperou um esforço de diminuição das diferenças em relação ao lado desenvolvido. Variando entre estas nações o grau de aprofundamento da industrialização e das relações tipicamente capitalistas, também foram altos os indices de crescimento da renda e do produto, muitas vezes superiores aos experimentados pelas nações mais adiantadas. Nas duas últimas décadas, contudo, tem ganhado força o reconhecimento de que os processos de industrialização acelerada verificados não promoveram, por um lado, a superação da condição de países "em desenvolvimento" e, por outro, levaram ao aprofundamento da concentração da renda e dos recursos produtivos. 
É esta a experiência do Brasil, que nas últimas décadas (com exceção da de 80), acelerou seu desenvolvimento econômico, tendo instalado um parque industrial de proporções consideráveis. Os benefícios advindos da prosperidade, contudo, foram desigualmente distribuídos. Os dados revelam que, no período 1960/1990, embora tenha havido aumento da renda real para todas as faixas de renda da população, o desenvolvimento experimentado foi limitado pelo sobre-favorecimento das camadas mais altas da distribuição. Com a estagnação do crescimento na década de 80 , acompanhada pelas contínuas altas dos índices inflacionários, acentuou-se o problema da desigualdade da distribuição de renda.

Esta tendência contínua à desigualdade durante décadas traçou o perfil da demanda brasileira: por ser um pais populoso, de dimensões continentais, encontra-se grande mercado para produtos relacionados à cesta básica de consumo, embora haja um contingente não desprezivel de miseráveis que nem mesmo tem acesso à maioria dos gêneros de primeira necessidade; há uma classe média de tamanho pequeno, relativamente às dimensões do país, cuja demanda apresenta-se mais diferenciada; por fim, um contingente da ordem de $10 \%$ da população que tem acesso a uma ampla gama de bens produzidos, destacando-se a faixa dos $1 \%$ mais ricos, que podem escolher, sem restrições, bens que lhe tragam satisfação.

O objetivo deste trabalho é trazer à tona a discussão de uma alternativa entre as propostas de retomada do desenvolvimento, qual seja a de promover uma redistribuição de renda em favor dos estratos de menor poder aquisitivo, buscando antever seus possíveis desdobramentos macroeconômicos em termos do crescimento e do desenvolvimento. 


\section{1 - A Importância do Tamanho do Mercado}

A economia mundial é hoje bastante internacionalizada, de forma que as fronteiras nacionais não têm a mesma conotação que tinham desde a formação dos Estados da Era Moderna até algumas décadas atrás. As economias estão de tal forma interligadas que os desdobramentos verificados em determinada nação afetam grande parte da economia mundial.

Não são apenas as dívidas externas dos países subdesenvolvidos que os tornam dependentes dos países centrais. Os mercados estão hoje muito mais integrados, sejam mercados de capitais ou de produtos. A recessão nos paises centrais afeta as decisões de investimentos não somente no âmbito destas economias, mas também nas nações menos desenvolvidas. A decisão de produzir determinada mercadoria tem muito a ver com a demanda por todo o globo, tal é a magnitude do intercâmbio vivido presentemente.

Durante as últimas décadas, manteve-se a economia brasileira com pequeno grau de abertura, fator que contribuiu para diminuir a competitividade de muitos bens produzidos internamente. Este resultado ficou evidente quando o processo de abertura comercial foi intensificado desde o início dos anos noventa e, em especial, a partir de 1994, com o advento do Plano Real.

A abertura, conjugada a outros desdobramentos do Plano, permitiu ao País experimentar o processo de globalização com maior profundidade. Assim, paralelamente à saturação do mercado para alguns produtos, como é o caso dos automóveis na Europa, o início da estabilização da economia brasileira, com chances de se confirmar no longo prazo, passou a atrair um número crescente de grandes empresas estrangeiras, interessadas na exploração do mercado interno brasileiro.

Desde as origens da literatura econômica clássica tem recebido destaque o papel do perfil da demanda. Adam Smith, logo nos capitulos iniciais de A Riqueza das Naçỏes, mostra preocupação com o tamanho do mercado. A 
discussão começa com a questão da divisão do trabalho, a qual traz ganhos surpreendentes de produtividade, fato ilustrado pela produção de alfinetes. Não faz sentido, contudo, organizar a produção de forma a alcançar maiores niveis de produtividade se a comunidade à qual se destinam as mercadorias for uma vila com pequena atividade econômica.

Assim, observa Smith, o uso de rios navegáveis para o comércio ampliou de forma incontestável a colocação de produtos por grande parte da Europa de então, revelando, numa linguagem atual, que o uso de tecnologia liga-se intimamente ao tamanho do mercado, ou ao perfil da demanda, fato que hoje é comprovado pela formação de um mercado mundial, em que as rotas de comércio cobrem intensamente o globo terreste, buscando novas oportunidades e levando à competição acirrada pelos consumidores.

\section{2 - A Desejada Retomada do Desenvolvimento}

Houve tempo em que o planejamento governamental pôde ser utilizado com possibilidades de êxito, digamos, até começo dos anos 70 . Seria desejável poder contar com este instrumento de política econômica, com o fim de tentar organizar alguns aspectos da economia nacional e direcionar as ações para um processo de desenvolvimento econômico acelerado. Mesmo hoje, algumas correntes de interpretação da economia brasileira continuam dando ênfase à idéia de elaboração de um projeto nacional. Subjacente a esta proposta está o desejo de que o país retome o caminho do desenvolvimento. Presente está, também, a noção de que há contexto favorável ao planejamento, como nos anos 60 ou 70 .

Aquele movimento anteriormente comentado, de internacionalização da economia mundial, contudo, acabou com as chances não só do Brasil, mas de

praticamente todas as nações capitalistas, de exercer o planejamento. É claro 
que variam, conforme o grau com que as economias nacionais sejam mais abertas ou fechadas, as possibilidades de atuar de forma pré-estabelecida, mas o campo de atuação é hoje muito mais reduzido. Em resumo, as economias nacionais perderam grande parte de sua soberania econômica.

Os E.U.A. são um dos exemplos vivos deste processo. Nação hegemônica durante quase todo este século, viu declinar sua posição de líder exclusivo da economia capitalista mundial. Justamente quando o mundo comunista desabou como experiência histórica, deixando a guerra fria para trás, o gigante americano foi obrigado a respeitar o poderio asiático, com destaque para o Japão, e europeu, onde se sobressai a Alemanha. A formação de grandes blocos comerciais, um processo relevante que ocorre paralelamente à globalização, é outro indicador da impossibilidade de planejamento nacional. As autarquias deverão ser condenadas à margem da economia mundial.

Malthus colocava o crescimento populacional como um entrave ao desenvolvimento, pelas necessidades crescentes de investimentos e de poupança. A doutrina neo-malthusiana, surpreendendo-se com o alto índice de crescimento populacional dos paises não desenvolvidos, não teve dificuldades em encontrar a razão pela qual estes não conseguiam se livrar do indesejado título e condição de país em desenvolvimento. Somente com o controle da natalidade tais países poderiam alcançar o status de nações desenvolvidas.

Esta tese, que ganhou força entre os economistas nacionais, é combatida por Paul Singer (1970), que mostra que as necessidades de capital e de investimentos para nações com alta taxa de natalidade estão dentro das possibilidades verificadas historicamente pelas nações não desenvolvidas, a fim de alcançarem o desenvolvimento. Dentro desta perspectiva, o crescimento populacional, antes de ser definido como um entrave ao crescimento, é encarado como uma excelente oportunidade de diversificação da atividade industrial, desde que o acréscimo populacional tenha condições de ser 
incorporado à economia de mercado, ou seja, tenha acesso pelo menos às mercadorias básicas produzidas.

Hoje o índice de crescimento populacional encontra-se em niveis inferiores aos apresentados nas décadas de 50 e 60 . A partir de 70 já se verifica uma desaceleração nas taxas de crescimento demográfico [ver MARTINE \& CARVALHO (1990)].

Sabe-se que a industrialização tem função autônoma no desenvolvimento, mas a retomada deste depende de fatores diversos. É necessário que os empresários tenham confiança no futuro, condição necessária para que os investimentos voltem a ocorrer em proporções condizentes com o crescimento. A estabilização joga aí papel fundamental.

Parece, também, estar o perfil da demanda extremamente diferenciado. As notícias a respeito do comportamento do consumo nos primeiros meses do Plano Real revelaram que as classes de baixa renda1, cujo contingente populacional é de grandes proporções, foram às compras de eletrodomésticos, esvaziando as prateleiras de lojas das grandes cidades.

O crédito, associado à queda da inflação e à fé no sucesso do plano, fez com que $45 \%$ dos consumidores de baixa renda da Grande São Paulo adquirissem ao menos um bem durável a partir de julho de 1994, segundo levantamento conduzido pela consultoria Interscience (Folha de São Paulo, 25.10.94). Mesmo com os salários "lá em baixo", nota-se o potencial representado pelas camadas de baixa renda da população brasileira. São necessários ajustes, contudo, para que o perfil da demanda seja conformado de maneira condizente com uma retomada do crescimento em bases seguras, vale dizer, de longo prazo.

\footnotetext{
1 A pesquisa considerou duas faixas de famílias de baixa renda: a própria, com renda mensal média de US $\$ 463,00$ e a de baixa renda alta, com renda de US\$1.033,00. Estas duas faixas representam, ainda segundo o levantamento, $19,8 \%$ e $34,5 \%$, respectivamente, do total da população. Abaixo da baixa renda, classificam-se os pobres, com renda de US\$245,00 e representando $21,3 \%$, e os miseráveis, com renda de US 67,00 e participação de $7,6 \%$ ná população total
} 
O principal objetivo do trabalho se refere ao estudo dos possiveis efeitos da redistribuição dos rendimentos, em favor dos que menos auferem, sobre o consumo e o investimento. Assim, há que se estudar criteriosamente a forma e o grau como poderão efetivar-se os intentos redistributivos. É possível afirmar que existe relação entre distribuição de renda e desenvolvimento? Em caso afirmativo, há condições de estimular o último com medidas redistributivas em favor das faixas menos favorecidas? Qual seria o impacto destas medidas sobre o perfil da demanda, ou sobre o tamanho do mercado?

O trabalho está organizado da seguinte forma: os capitulos 2 e 3 contribuem para contextualizar devidamente o tema da distribuição de renda no Brasil. No capítulo 2, trata-se do estudo da distribuição funcional. Ainda é pouco conhecido este enfoque, o que tem levado à divulgação de indicadores equivocados, e por sua vez, a interpretações exageradas no que diz respeito ao grau de desigualdade entre as categorias de renda.

No capítulo 3 é feita uma recapitulação da distribuição pessoal da renda no Brasil nas últimas décadas. Este tema possui ampla bibliografia, de forma que o capitulo é uma tentativa de agrupar os textos já escritos, com o fim de encaminhar o leitor a um maior conhecimento de como se comportou a distribuição pessoal da renda historicamente em período recente no Brasil.

Finalmente, no capítulo 4 estuda-se especificamente o tema que motivou toda a pesquisa: o comportamento da demanda agregada num contexto de redistribuição dos rendimentos. Além da discussão da questão teórica envolvendo o assunto, são estudadas algumas propostas de redistribuição da renda em favor dos estratos mais baixos da distribuição, buscando visualizar possíveis desdobramentos. 


\section{2 - A PARTICIPAÇÃO DOS SALÁRIOS NA RENDA NACIONAL}

Quando se fala em Distribuição de Renda, é sempre bom lembrar que há dois enfoques na tradição analítica do assunto: Distribuição Funcional e Distribuição Pessoal da Renda.

A primeira, também chamada de Distribuição Fatorial, trata da apropriação dos rendimentos pelas categorias econômicas básicas, trabalho e capital; ou trabalho, capital e terra. A Distribuição Pessoal trata da apropriação dos rendimentos pelas familias, ou ainda, pelos indivíduos.

Exemplificando, na Distribuição Funcional são comuns as definições do tipo: juros, lucros, aluguéis, salários etc. Na Pessoal fala-se a respeito dos $40 \%$ mais pobres, $10 \%$ mais ricos, classes baixa, média e alta, estratos da distribuição etc.

No presente capítulo estar-se-á tratando da distribuição funcional da renda, incentivado pela divulgação recente, em artigos da literatura especializada e em jornais, de que a participação dos salários na renda nacional é de $38 \%$, ou mesmo $30 \%$. Logicamente, a fração destinada aos demais rendimentos (juros, lucros, aluguéis etc.) é de $62 \%$ (ou $70 \%$ ).

O Departamento Intersindical de Estatística e Estudos SócioEconômicos - DIEESE - divulgou em seu Anuário dos Trabalhadores de 1993 que, segundo dados do IBGE, a participação dos salários e rendimentos do trabalho na renda interna bruta urbana era de $56,6 \%$ em 1949 , passando a $38,0 \%$ em 1988. Na seção Documentos da Revista de Economia Política, um texto de LACERDA (1994) cita a publicação do DIEESE, assumindo o 
percentual de $38,0 \%$ como a participação dos salários na renda nacional total. O uso do percentual com certa falta de rigor compromete interpretações que provavelmente venham a ser feitas. Contudo, mais importante, o fato de que o dado do DIEESE refira-se à renda urbana leva-nos a crer que a participaçãosalarial na renda nacional total seria ainda mais baixa, devido ao conhecido fato de serem menores as taxas de assalariamento do trabalho no campo.

No Boletim DIEESE $n^{0} 163$, de outubro de 1994, o primeiro artigo, intitulado "Brasil precisa de justiça social" (pp.3-5), afirma à p.4 que a fatia correspondente aos salários é de $30,0 \%$, contra $70 \%$ de participação dos juros, lucros, aluguéis etc.

O economista Joelmir Beting, em longo artigo publicado na revista Veja, em dezembro de 1996, fala de um "arrocho dantesco" do salário real médio que fez com que "a fatia do trabalho na renda nacional" despencasse "de $51 \%$, em 1984, para menos de 30\%, em 1993, segundo o DIEESE." (Veja, 25/12/96, p.159)

Nota-se, portanto, que começa a se tornar corrente o uso dos dados do DIEESE, com a agravante de que a publicação de 1994 divulga uma participação dos salários na renda ainda menos significativa. Como será visto adiante, o percentual de $38,0 \%$ é baixo ( $30,0 \%$ mais ainda), seja em comparação com economias de industrialização tardia como a nossa, seja, ainda mais, em relação aos países centrais.

Torna-se oportuno (e mesmo necessário), portanto, conhecer com maiores detalhes a participação dos salários na renda, pelo menos por dois motivos: o primeiro, porque ainda é pouco conhecida a distribuição funcional da renda no pais; o segundo, em virtude de buscar uma explicação para os índices recentemente divulgados, questionando o que há de verdadeiro, relativamente aos dados disponiveis, naqueles percentuais. 
A primeira pergunta que surge vem questionar a comparabilidade dos dados entre países. A participação dos salários na renda é estimada, normalmente, a partir das Contas Nacionais, o que possibilita fazer comparações.

As Contas Nacionais são um conjunto de informações quantitativas, que buscam retratar a vida econômica do país, de forma a possibilitar o conhecimento das características e transformações estruturais, bem como o acompanhamento de sua evolução.

Desde o pós-guerra, as Nações Unidas, em nível global, e a Comunidade Econômica Européia, no âmbito dos países membros, têm buscado normatizar os avanços na área, esforçando-se pela definição de um modelo conceitual padronizado que deve ser tomado como referência pelos diversos paises.

No Brasil, a partir da década de 40, a Fundação Getúlio Vargas encarregou-se da elaboração das Contas Nacionais seguindo padrōes internacionais, dentro do que é conhecido como Sistema de Contas Nacionais Consolidado (SCNC). Os dados são disponiveis para comparação a partir de 1947. Em dezembro de 1986 passou para a Fundação Instituto Brasileiro de Geografia e Estatística (Fundação IBGE) esta atribuição, onde permanece até os dias de hoje.

A fim de aprofundar o conhecimento da distribuição funcional da renda, bem como estabelecer comparações com maior propriedade, é necessário conhecer as especificidades do mercado de trabalho brasileiro. Mais à frente, será estudada a metodologia de mensuração do agregado "participação dos salários na renda". 


\section{1 - O Mercado de Trabalho no Brasil}

\subsection{1 - O Período 1940/1980}

Uma análise do mercado de trabalho brasileiro a partir da década de 40 tentará captar as principais características estruturais do mesmo, dentro dos objetivos perseguidos por este trabalho. Como será visto no próximo capítulo, é a partir desta década que se intensificam os investimentos produtivos no Brasil, empurrados pelo movimento de substituição de importações e tendo o Estado como agente articulador das grandes decisões. A década de 80 marca uma mudança de rumo nos caminhos trilhados pela nação: o ciclo de crescimento é interrompido e a inflação cresce de forma assustadora.

Em 1940, a População Economicamente Ativa (PEA) do país era composta por cerca de 15 milhões de pessoas. O conceito de PEA (Estatísticas Históricas do Brasil, IBGE, 1990, p.65) é o de todos os ocupados, bem como os temporariamente desempregados, e também os religiosos, os membros das forças armadas e os membros de família que trabalham auxiliando o chefe de familia, sem receberem diretamente, contudo, qualquer tipo de remuneração. Em 1980, o total da PEA no Brasil já alcançava 44 milhões de trabalhadores. Em termos anuais, o crescimento foi em torno de 2,7\%, igual ao crescimento populacional no periodo e um pouco inferior ao crescimento das pessoas de 10 anos e mais, conforme a Tabela 1, reproduzida de CHAHAD \& LUQUE (1984, p.32). 
Tabela 1

Taxas de Crescimento Anual dos Diversos Setores da PEA BRASIL: $1940 / 1980$ (\% a.a.)

\begin{tabular}{lccccc}
\hline SETOR DE ATIVIDADE & $1940 / 50$ & $1950 / 60$ & $1960 / 70$ & $1970 / 80$ & $1940 / 80$ \\
\hline Agrop.e Extr.Vegetal & 0,5 & 1,8 & 0,6 & 0,01 & 0,8 \\
Comércio & 3,1 & 4,6 & 4,3 & 6,2 & 4,6 \\
Serviços & 2,2 & 6,0 & 3,8 & 6,1 & 4,5 \\
Indústria & 4,9 & 1,9 & 6,0 & 7,3 & 5,0 \\
Administração Pública & 3,0 & 4,1 & 5,5 & 5,3 & 4,5 \\
Total da PEA & 1,5 & 2,9 & 2,6 & 4,0 & 2,7 \\
Tot. pop. 10 anos e + & 2,3 & 2,9 & 3,0 & 2,9 & 2,8 \\
Total da população & 2,3 & 3,0 & 2,9 & 2,5 & 2,7 \\
\hline
\end{tabular}

Fonte: Anuário Estatístico do Brasil, 1982, conforme Chahad e Luque (1984, p.32)

Analisando as tabelas 1 e 2 , logo chama a atenção a perda de dinamismo (embora dados anteriores não estejam sendo mostrados, o que reforçaria o argumento) e consequente perda de participação do setor agrícola, extrativismo vegetal e pesca no total da PEA. Esta é uma das faces da mudança estrutural da economia brasileira no pós-Segunda Guerra. Maior setor na absorção de trabalhadores desde 40 (ou melhor, desde as origens da história econômica do Brasil), vai perdendo participação até que em 1980 chega a menos da metade do nível apresentado em 40. Em termos absolutos, o setor primário absorvia perto de 10 milhões de trabalhadores em 1940, passando a 13 milhões em 1980. Um crescimento anual de $0,8 \%$ em 40 anos, contra um crescimento da população e da PEA de $2,7 \%$ no mesmo período, revela a perda de importância relativa do setor na geração de empregos. 


\section{Tabela 2}

População Economicamente Ativa Segundo Setor de Atividade

BRASIL: $1940 / 1980$

$\%$ sobre o Total da PEA

\begin{tabular}{lccccc}
\hline SETOR DE ATIVIDADE & 1940 & 1950 & 1960 & 1970 & 1980 \\
\hline Agrop.e Extrat.Vegetal & 65,8 & 59,9 & 54,0 & 44,3 & 29,9 \\
Comércio & 4,7 & 5,5 & 6,5 & 7,6 & 9,4 \\
Serviços & 16,3 & 17,4 & 23,5 & 26,3 & 32,2 \\
Indústria & 10,4 & 14,2 & 12,9 & 17,9 & 24,4 \\
Administração Pública & 2,8 & 3,0 & 3,1 & 3,9 & 4,1 \\
\hline
\end{tabular}

Fonte: Anuário Estatístico do Brasil (1982), em CHAHAD \& LUQUE (1984)

Por outro lado, a indústria vem comprovar seu fortalecimento como setor econômico ao apresentar a maior taxa de crescimento da população ativa no período 40/80: 5,0\% ao ano. Apenas na década de 50 sua taxa de crescimento é inferior à dos demais setores, e inclusive bastante baixa. Em que pese estarem sendo feitos inúmeros investimentos nesta época, a absorção de mãode-obra se deu em menor ritmo em função da importação de tecnologias intensivas na utilização de capital. No período como um todo, contudo, o dinamismo da indústria é notável: sua participação na PEA vai de cerca de $10 \%$ em 1940 para mais de $24 \%$ em 1980 . Em termos absolutos, ela emprega em 80 mais de dez milhões de trabalhadores, enquanto em 40 empregava cerca de um milhão e meio. Se se considera o poder multiplicador da indústria ao gerar necessidades de atividades de comércio e serviços, confirma-se a importância crucial da industrialização do país na atenuação do problema da criação de empregos.

Comércio e Serviços apresentam taxas anuais de crescimento entre 1940 e 1980 da ordem de 4,6\% e 4,5\%, passando, conjuntamente, de uma 
participação na PEA de $21,0 \%$ para $41,6 \%$, ou seja, o setor terciário é o que tem a maior absorção de mão-de-obra em 1980: dezoito milhões de trabalhadores, em termos absolutos. Esta constatação é importante em termos da qualidade dos postos de trabalho que são gerados pelo setor: sabe-se que grande parte da informalidade do mercado de trabalho brasileiro, a ser discutida, encontra-se no setor terciário.

A Administração Pública vai ganhando espaço durante todas as décadas do período analisado, ocorrendo com maior intensidade nos anos sessenta e setenta. Uma participação de $4,1 \%$ no total da PEA não é de forma alguma desprezivel, correspondendo a quase dois milhões de funcionários públicos em 1980.

De uma forma geral, estes desdobramentos mostram que a força de trabalho brasileira passou por uma modificação estrutural ao longo do periodo. Uma população que estava voltada primordialmente às atividades agrícolas, estabelecida no campo, experimentou uma mudança radical em seu modo de vida: atraída pelas oportunidades oferecidas nas cidades, incorporou-se às atividades industriais, comerciais e de serviços. É claro que as gerações mais novas tiveram maiores oportunidades de melhores empregos na cidade relativamente às gerações que primeiramente chegaram. Grandes parcelas tiveram acesso à educação, vindo a exercer empregos, especialmente na indústria, com remuneração média mais alta. Por outro lado, um contingente também não desprezível, de pessoas com pouca ou nenhuma qualificação, veio a participar do mercado de trabalho em suas esferas inferiores: baixa remuneração, baixa taxa de registro, quase impossibilidade de melhora ao longo do periodo de vida trabalhista.

Duas outras tabelas, tiradas da mesma obra de CHAHAD \& LUQUE (1984), vêm completar a análise desenvolvida neste capítulo para o período 1940-80. 


\section{Tabela 3}

Força de Trabalho Segundo Sexo e Idade

BRASIL: 1950/80

\begin{tabular}{|c|c|c|c|c|c|c|c|c|c|}
\hline & \multicolumn{3}{|c|}{1950} & \multicolumn{3}{|c|}{1970} & \multicolumn{3}{|c|}{1980} \\
\hline \multirow[t]{3}{*}{ Faixa Etária - Anos } & & Taxa & & & Taxa & & & Taxa & \\
\hline & \multicolumn{3}{|c|}{ Participação ${ }^{1}$} & \multicolumn{3}{|c|}{ Participação ${ }^{1}$} & \multicolumn{3}{|c|}{ Participação' } \\
\hline & $\mathrm{H}$ & $M$ & $\mathrm{~T}$ & $\mathrm{H}$ & $M$ & $\mathrm{~T}$ & $\mathrm{H}$ & $M$ & $\mathrm{~T}$ \\
\hline 10 a 14 & 31 & 9 & 20 & 19 & 6 & 13 & 20 & 8 & 14 \\
\hline 15 a 19 & 81 & 24 & 51 & 63 & 25 & 44 & 65 & 31 & 48 \\
\hline 20 a 24 & 97 & 20 & 56 & 91 & 29 & 59 & 90 & 39 & 64 \\
\hline 25 a 29 & 97 & 15 & 55 & 96 & 23 & 58 & 96 & 36 & 66 \\
\hline 30 a 39 & 97 & 13 & 55 & 98 & 33 & 72 & 97 & 35 & 66 \\
\hline 40 a 49 & 96 & 13 & 56 & 95 & 20 & 58 & 93 & 31 & 62 \\
\hline 50 a 59 & 93 & 11 & 53 & 87 & 16 & 51 & 84 & 22 & 52 \\
\hline 60 a 69 & 83 & 12 & 47 & 70 & 10 & 40 & 58 & 11 & 34 \\
\hline 70 anos e + & 60 & 7 & 30 & 44 & 3 & 26 & 24 & 3 & 13 \\
\hline Total & 81 & 15 & 48 & 73 & 20 & 47 & 73 & 27 & 50 \\
\hline
\end{tabular}

Fonte: Censos Demográficos do IBGE

${ }^{1}$ Definida como a divisão da PEA pela População de 10 Anos e Mais, para cada gênero.

$\mathrm{H}=$ homem; $\mathrm{M}=$ mulher; $\mathrm{T}=$ total. 


\section{Tabela 4}

Taxas de Crescimento Anual da PEA Masculina e Feminina

BRASIL: 1950/1980 (\% a.a.)

\begin{tabular}{lccc}
\hline População & $1950 / 1970$ & $1970 / 1980$ & $1950 / 1980$ \\
\hline PEA & 4,2 & 6,9 & 5,1 \\
Mulheres & 2,4 & 3,1 & 2,6 \\
Homens & & & \\
& & & \\
Pop.de 10 anos e + & 2,6 & 3,7 & 3,0 \\
Mulheres & 2,9 & 3,1 & 3,0 \\
Homens & & & \\
\hline
\end{tabular}

Fonte: Censos Demográficos do IBGE

Quanto à faixa etária, uma pequena diminuição na participação dos mais jovens (até 19 anos) está ocorrendo, em virtude da ampliação do período de escolaridade, característica comumente encontrada em países em processos de industrialização, com a ressalva de que no Brasil a queda é bem menos significativa. Do outro lado da composição etária, as faixas a partir de 60 anos também perdem participação, porém com maior intensidade.

O maior destaque nas alterações ocorridas no perfil da PEA no periodo cabe às mulheres. Já entre 1950 e 1970 a população ativa feminina está crescendo a taxas que representam quase o dobro do crescimento da participação masculina. Na década de setenta, contudo, é que se observa um ritmo muito mais intenso do crescimento da mão-de-obra feminina no mercado de trabalho: quase $7 \%$ ao ano. $O$ resultado é que as mulheres aumentam sua taxa de participação (conforme definida acima) de $15 \%$ para $27 \%$ no periodo 1950/80. Fatores culturais e econômicos contribuíram para este desempenho, de maneira que com a industrialização e a lenta e pequena queda na importância dos valores tradicionais (que pelo lado pessoal incutiam nas 
mulheres aspirações restritas a uma vida de dona-de-casa, e pelo lado do mercado de trabalho, dominado pelos homens, discriminavam contra a participação feminina na quase totalidade das atividades), as mulheres, paulatinamente, vêm a ocupar posições as mais variadas.

Em termos do volume de emprego, as atividades que mais contribuiram para o aumento da participação feminina foram as de caráter social e o trabalho doméstico remunerado. Na década de setenta, dado o vigor apresentado pela economia em seu crescimento, especialmente na primeira metade, quando esteve operando próxima ao pleno emprego dos fatores, as oportunidades abertas à força de trabalho feminina foram grandes em quantidade e qualidade.

Fechando este item, duas ressalvas devem ser feitas: a primeira referese à precariedade dos dados referentes ao desempenho dos salários no período. Com exceção da década de setenta, quando passam a ser publicadas coberturas mais amplas do mercado de trabalho, com destaque para as atividades industriais, pouco se pode fazer em termos de uma análise mais efetiva quanto ao assunto. Opta-se, neste capítulo, por privilegiar a década de oitenta com uma cobertura mais completa. A segunda ressalva diz respeito às relações entre o mercado de trabalho e a Participação dos Salários na Renda. Conforme pode ser visto adiante, na Tabela 5 (p. 32), de 70 a 75 cai em cerca de quatro pontos percentuais (de 40,7 para 36,5 ) a participação dos salários na renda, a qual se recupera levemente em 1980, chegando a 38,7\%. Entre 1970 e 1980, dado que tivemos fatores que atuaram em dois sentidos (para uma maior ou menor participação dos salários na renda), torna-se difícil avaliar quais tiveram maior peso na determinação daquele agregado. Veja-se: a significativa queda na participação do Setor Primário, que passa de $44,3 \%$ para $29,9 \%$, contribui para uma maior participação salarial, uma vez que os salários urbanos são maiores que os rurais, e também o alcance das regulamentações trabalhistas é menor no campo. A maior participação da indústria no total da 
PEA também colabora no mesmo sentido. Contudo, a maior participação das mulheres contribui para um achatamento dos salários pagos, como é conhecido. Sem uma análise do comportamento dos salários estas afirmações devem ser cuidadosamente utilizadas.

\subsection{2 - A Década de 80 e os Anos Iniciais da de 90}

Os anos oitenta são conhecidos como a década perdida, dado que o crescimento do produto per capita foi praticamente nulo. O Brasil foi obrigado a realizar seu ajuste recessivo, como forma de geração de superávits comerciais a fim de possibilitar condições de solvência no que se refere ao pagamento de juros e principal da divida externa outrora contraída.

Embora seja uma década de estagnação produtiva, o comportamento do mercado de trabalho foi notável da perspectiva da geração de novos postos de trabalho. Conforme mostram AMADEO et alii (1994, p.1), a criação de empregos só foi um problema crítico no ano de 1983. Tendo o Produto Interno Bruto crescido a uma taxa média de 1,5\% ao ano, o nível de emprego cresceu continuamente durante os anos oitenta à taxa também média de $3,5 \%$ ao ano, superando a taxa de crescimento populacional no período, que foi de $2,1 \%$. A população ocupada, em termos absolutos, salta de 45,5 milhões em 1981 para 62,1 milhões em 1990, o que corresponde à criação de mais de 16 milhões de novos postos de trabalho. 


\section{Gráfico 1}

Crescimento do Emprego na Década de 80

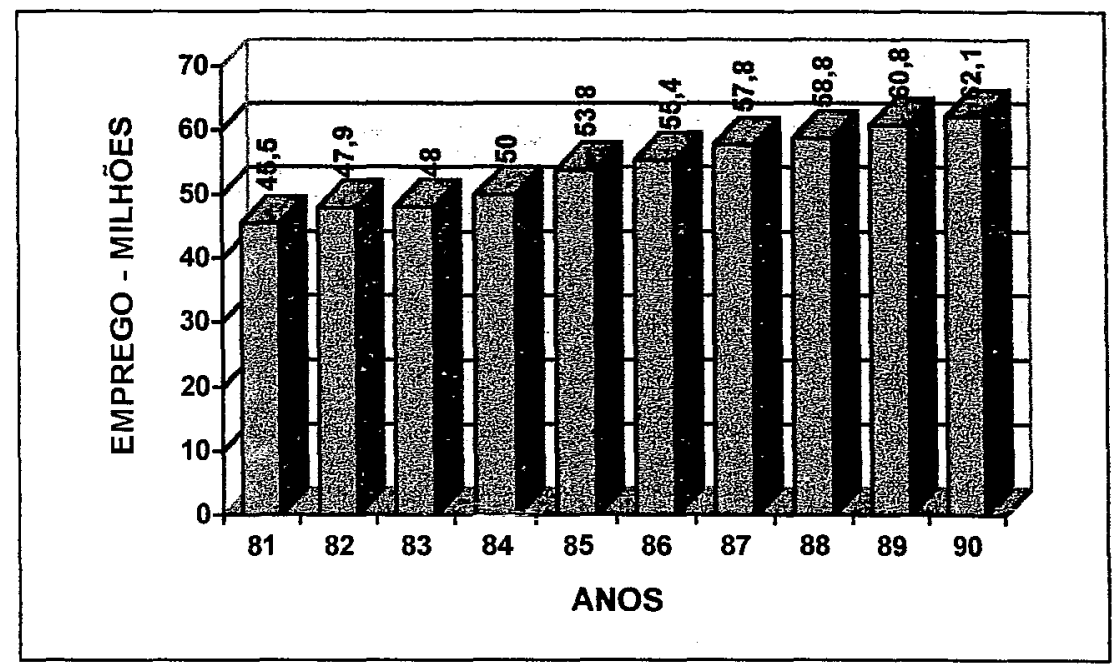

Fonte: Pesquisa Nacional por Amostra de Domicilios (PNAD), em AMADEO et alii (1994)

Comparando as taxas de crescimento do emprego nas décadas analisadas na seção anterior e na década de 80 (lembrando que naquelas as taxas se referem à PEA e nesta ao pessoal ocupado - a diferença é que a PEA considera também os temporariamente desempregados, de forma que em se tratando de comparação entre taxas de crescimento o resultado é pouco afetado), tem-se que os maiores índices referem-se à década de 70 . Nesta, um crescimento anual de $4,0 \%$ se fez presente. Nos anos 80 , a taxa anual situouse na casa dos $3,5 \%$. Levando-se em conta as dificuldades econômicas vividas na última década, e lembrando que o produto nas décadas de 40,50 e 60 cresceu significativamente, chega a ser baixo o crescimento da PEA nestas, respectivamente, da ordem de $1,5 \%, 2,9 \%$, e $2,6 \%$ ao ano.

A grande capacidade de absorção de mão-de-obra nos anos oitenta tem como contrapartida a manutenção de baixas taxas de desemprego aberto. Como se pode ver no Gráfico 2, algumas flutuações ocorrem durante toda a década, mas níveis acima de $4 \%$ só se encontram até 1984 . Ao final do período 
recessivo de 1981/83, verifica-se a maior taxa de desemprego: $4,9 \%$, que com a recuperação dos anos seguintes declina para 2,5\% em 1986. De 1987 a 1990 a taxa fica em torno de 3,5\%. Entre 1991 e 1995, a partir de dados da Pesquisa Mensal do Emprego/IBGE, apresentadas em URANI (1996, p.133), a taxa de desemprego aberto esteve ao redor de $5 \%$.

\section{Gráfico 2}

Taxa de Desemprego Aberto

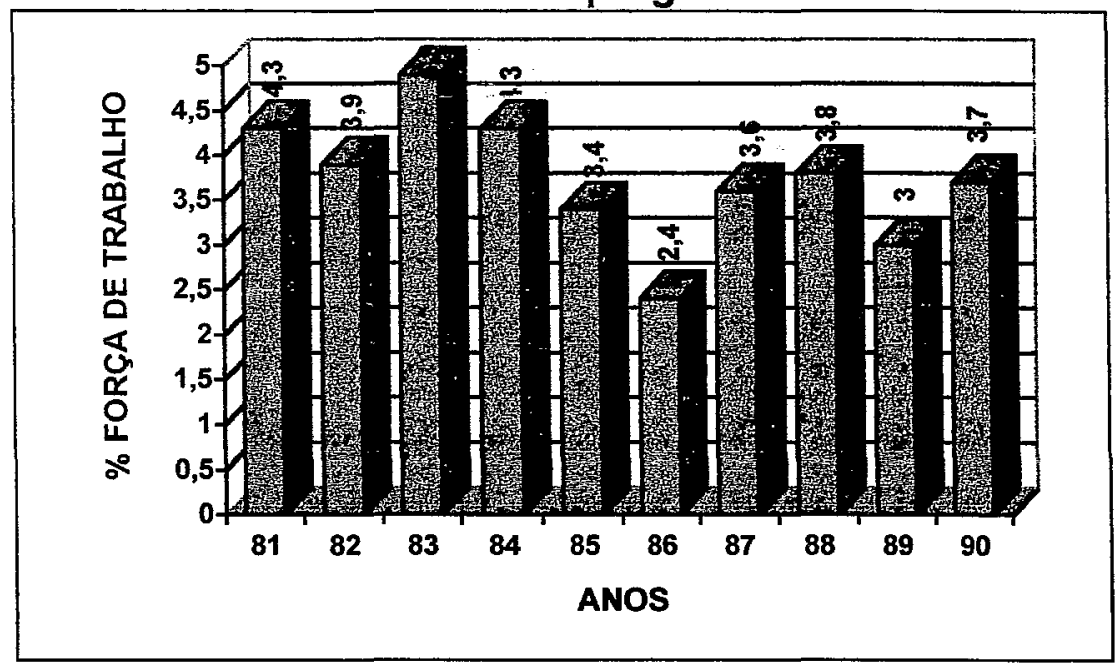

Fonte: PNAD, em AMADEO et alii (1994)

Como não poderia deixar de ser, graças à grande capacidade de absorção apresentada, a Taxa de Participação no Mercado de Trabalho mostrou-se crescente ao longo da década (ver Gráfico 3). Em comparação com os dados anteriores, este é mais um indicador do excelente desempenho apresentado pelo mercado de trabalho brasileiro: de 1950 a 1980, a taxa de participação passa de $48 \%$ para 50\%, ao passo que de 1981 a 1990 ocorre um aumento de mais de três pontos percentuais. 


\section{Gráfico 3}

Taxa de Participação

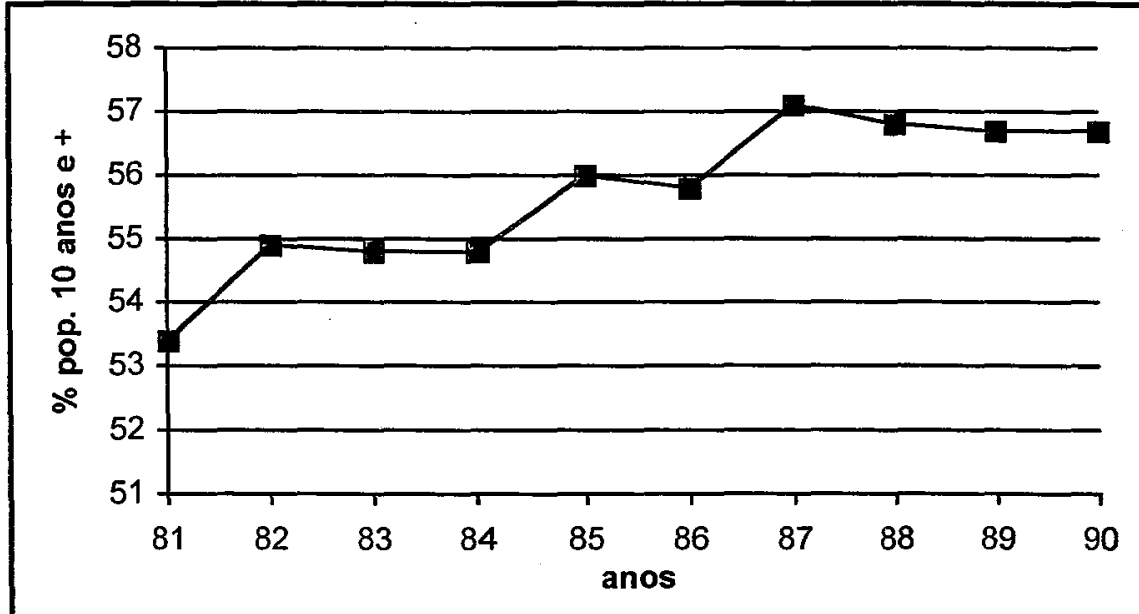

Fonte: PNAD, em AMADEO et alii (1994)

Uma vez descartada a ocorrência de dificuldades no que se refere à quantidade dos postos de trabalho gerados, o problema associado ao emprego na década de oitenta pode estar associado a fatores qualitativos. Examinemos como se comportaram a evolução do rendimento médio e da estrutura setorial do emprego.

\section{Gráfico 4}

\section{Evolução da Renda Real Média do Conjunto da Força de} Trabalho, 1981-1990 - Brasil

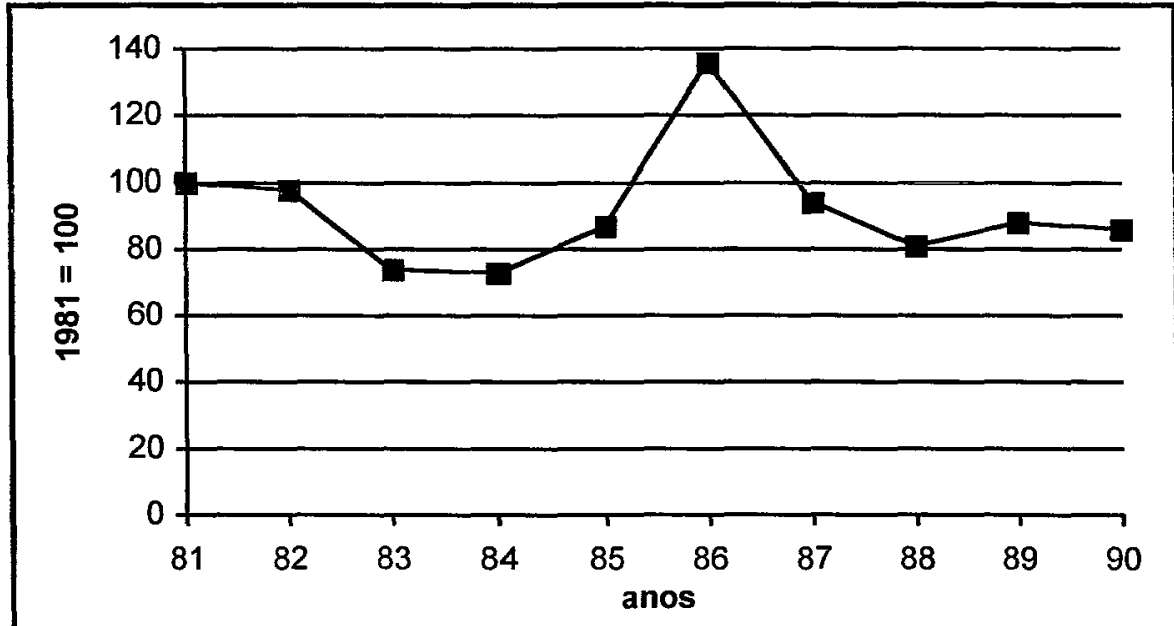

Fonte: Pesquisa Mensal de Emprego, em AMADEO et alii (1994). Deflator: INPC 
Nota-se, considerando os extremos do período, que o rendimento médio sofre uma queda de $14 \%$. A produtividade, definida como a relação PIB/trabalhador, declina em $17 \%$ no mesmo periodo, fruto da expansão do emprego em níveis superiores ao do crescimento do produto. $O$ comportamento da renda, contudo, é bastante irregular no decorrer dos anos, seguindo as oscilações no produto somadas à tendência de queda, necessária para acomodar o aumento do emprego com produtividade declinante.

A estrutura setorial do emprego revela um inchamento daqueles mais intensivos em mão-de-obra, os quais pagam salários mais baixos. Este fator relaciona-se com o desempenho da renda, contribuindo para a queda verificada. Por outro lado, todas as atividades tiveram sua renda diminuída no período [AMADEO et alii $(1994$, p.8)].

O Gráfico 5, a seguir, revela que a distribuição de trabalhadores por setor de atividade econômica modificou-se bastante ao longo dos anos oitenta. O setor terciário, excluindo administração pública, passa de $43 \%$ para quase $49 \%$ de participação na PEA. O setor primário, por outro lado, mantém sua tendência declinante de décadas, passando a representar cerca de $22,5 \%$ do total da ocupação em 1989. O secundário mantém sua participação em torno de $23 \%$. Retomando as comparações com as décadas anteriores, vemos que a década de 80 rompe um padrão de evolução setorial que se conformou nas quatro décadas anteriores: o de crescimento da indústria, acompanhado de perto pelo comércio e serviços, revelando um crescimento equilibrado da composição setorial. $\mathrm{Na}$ "década perdida", dispara o terciário na geração de empregos, ficando estagnada a absorção de trabalhadores pela indústria. 


\section{Gráfico 5}

\section{Distribuição da força de trabalho por setor da atividade econômica}

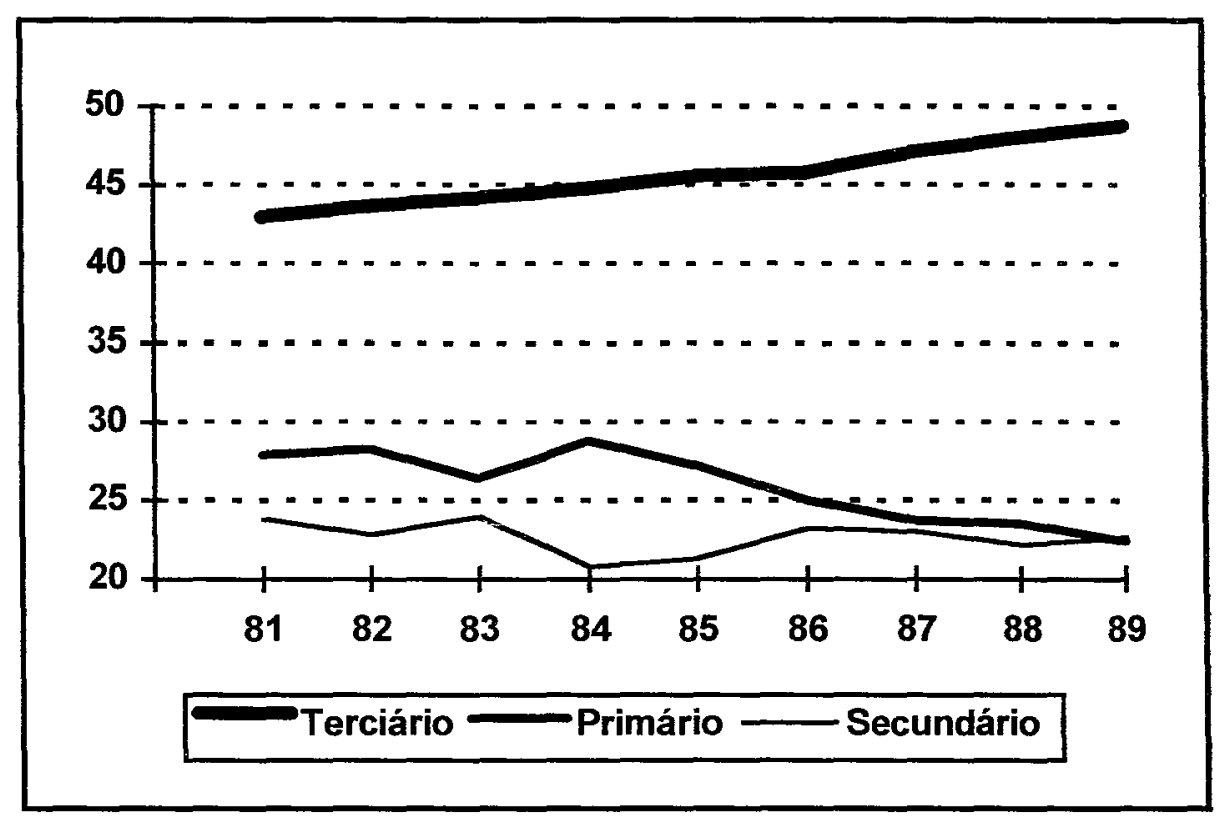

Fonte: PNAD, em AMADEO et alii (1994)

Nos países capitalistas de um modo geral, foi comum o desenvolvimento do setor terciário durante as fases de industrialização, mas num ritmo próximo ao do crescimento das atividades secundárias. Recentemente, as nações desenvolvidas revelam tendência de valorização dos serviços, em virtude, entre outros fatores, da acentuação do modo de vida urbano moderno e da crescente importância da tecnologia da informação (T.I.). Na década de 80 , contudo, o inchamento do terciário no Brasil esteve relacionado com a crise econômica, manifestada em parte pela ocupação de postos de trabalho de baixa remuneração e pela busca de soluções individuais em pequenos empreendimentos do setor informal. Embora não tenha sido forte a tendência à informalização nos anos oitenta, será dado destaque ao conhecimento da informalidade no Brasil, bem como ao esclarecimento da controvérsia setor informal/economia não registrada ou ilegal, por se considerar o fenômeno importante dentro do mercado de trabalho brasileiro e na inter-relação com o 
tema central do capítulo - a participação dos salários na renda. Ademais, os fatos ocorridos nos anos iniciais da década de 90 , quando aumentou de forma notável a participação do setor informal na economia, também incentivam uma análise mais detalhada do assunto.

\subsection{3 - A Segmentação do Mercado de Trabalho}

Inicialmente, deve-se questionar a existência ou não de segmentação no mercado de trabalho. No pós-Segunda Guerra a literatura econômica especializada deu ênfase à constatação de dois setores no capitalismo em geral: o moderno, que englobaria as atividades com tecnologia em constante progresso, e o tradicional, que abarcaria os setores em processo de esgotamento do progresso tecnológico. Dessa forma, identificou-se o setor de bens de consumo não-durável (alimentos processados etc) como parte do segmento tradicional $e$ os setores de bens de consumo durável (eletrodomésticos etc) e bens de capital (máquinas e equipamentos produtivos) no segmento moderno. Depois de muito tempo, foi sendo abandonada esta abordagem, graças à dinâmica do capitalismo, cujo exemplo maior está no revigoramento tecnológico de todos os setores econômicos, em consonância com consumidores cada vez mais exigentes, para todos os tipos de produtos.

A partir de um diagnóstico sobre emprego e renda da economia queniana, publicado pela OIT (1972), uma nova forma de caracterização do mercado de trabalho passou a ser utilizada: a que define a presença dos setores formal e informal. O processo de desenvolvimento experimentado pelo Quênia, assim como o da maioria dos países que se esforçaram em prol da industrialização como forma de superar o subdesenvolvimento, redundou na criação de grupos significativos de diferentes inserções na estrutura produtiva, bem como tipos de ocupações que fugiam à caracterização teórica e operacional, baseada no dualismo moderno/tradicional. Essas atividades e 
ocupações, embora tivessem sido criadas dentro da dinâmica do processo de desenvolvimento (o que levaria a enquadrá-las no setor moderno), apresentavam características como: utilização de trabalho não assalariado e baixo nível de remuneração (por esta última, deveriam ser classificadas no setor tradicional). Assim é que se propõe uma nova forma de caracterização da segmentação no mercado de trabalho: a divisão entre os setores formal e informal (CACCIAMALI, 1989b, p.605).

Este novo enfoque, presente no estudo da OIT a respeito da economia queniana, define o setor informal a partir das relações de produção e do trabalho, ou seja, da observação direta da dinâmica dos mercados. Neste sentido, as unidades informais são assim classificadas por utilizarem pouco capital, insumos não importados, técnicas simples e intensivas em trabalho, pequeno número de trabalhadores, remunerados e/ou membros da família e, de forma geral, com pouca ou nenhuma qualificação. As unidades produtivas inseridas neste segmento, no qual se incluem os trabalhadores autônomos, ou por conta própria, também se caracterizam por atuar em mercados competitivos, não possuir acesso a linhas oficiais de crédito e não serem objeto de políticas governamentais. Apenas recentemente, no ano de 1996, permitiuse aos bancos brasileiros abrir linhas de crédito ao setor informal, e o governo se mobilizou para elaborar sua política nessa área.

CACCIAMALI (1989b, p.609) resume o amadurecimento do conceito de setor informal através do tempo com uma definição onde o importante é o fato de não ocorrer a separação entre trabalho e capital:

"i) o produtor direto é proprietário dos instrumentos de trabalho e/ou estoque de bens para realização de seu trabalho e se insere na produção sob a forma simultânea de patrão e empregado; ii) ele emprega a si mesmo e pode lançar mão de trabalho familiar ou de ajudantes como extensão de seu próprio trabalho; obrigatoriamente participa diretamente da produção (de bens ou serviços) e conjuga esta atividade com aquela de gestão." 
Na linha desta definição, o setor informal diferencia-se do formal: 1) pela diferença na racionalidade econômica do empreendimento: enquanto no setor formal é comum a maximização da taxa ou da margem de lucro, objetivando um processo de acumulação, nas atividades informais o que se busca maximizar é a renda líquida total, buscando, em primeiro lugar, a manutenção do produtor e de sua família e, depois, a sobrevivência do negócio; 2) pela facilidade dos que trabalham na produção conhecerem e participarem de todas as etapas do processo produtivo. Sabe-se que nas atividades formais os trabalhadores acabam por se especializar em atividades que representam pequena parcela da produção, e quanto maior é a unidade produtiva, maior é a especialização e separação das etapas da mesma.

No setor informal, o caráter de pequenas unidades permite ao produtor $\mathrm{e}$ aos que com ele participam do processo produtivo apreender o conjunto das atividades, para o que contribui a utilização de técnicas relativamente simples. Por outro lado, embora normalmente as técnicas não sejam complexas, o produtor informal necessita conhecer um conjunto de informações vitais acerca do mercado em que atua, e inclusive estar se atualizando frequentemente, a fim de manter suas atividades em nivel competitivo.

$\dot{E}$ imperioso destacar que nem sempre se deve referir à informalidade como um fenômeno prejudicial, quer para os que nela ingressam, quer para a economia em geral. Alguns estudos na área têm o costume de propor políticas que visem a diminuir a abrangência do setor informal na economia, com a convicção de que indivíduos obterão vantagens ao passar para o lado formal, e a nação será beneficiada.

Ora, em primeiro lugar, a informalidade constitui preciosa oportunidade de sobrevivência para um amplo contingente da mão-de-obra não qualificada, ou com pouca qualificação para os cargos oferecidos pelo setor formal, o mesmo ocorrendo em épocas de grande desemprego. Ainda neste sentido, a atividade informal, quando exercida espontaneamente, pode trazer satisfação $e$ 
rendas maiores do que seria possivel auferir nas atividades formais. Em segundo lugar, a informalidade está presente em todos os países capitalistas do planeta, em maior ou menor grau.

Mesmo entre os sete principais países industrializados, a participação dos trabalhadores por conta própria (atividade normalmente classificada como típica do setor informal) e dos trabalhadores não remunerados, entre 1980 e 1987, em termos percentuais era: Estados Unidos, 8,71; Canadá, 9,35; Alemanha, 11,76; França, 14,55; Japão, 24,06 e Itália, 25,73 (CACCIAMALI, 1989 b, p.611). No Brasil esta participação, na PNAD de 1988, situa-se em $30,59 \%$, um nível aceitável para um país em desenvolvimento. Políticas que visem uma melhora na estrutura trabalhista e na renda devem antes dotar de melhores condições de funcionamento todos os segmentos informais.

O SEBRAE - Serviço Brasileiro de Apoio às Micro e Pequenas Empresas tem se destacado no apoio às microempresas, cujas características as fazem participar, em grande medida, do setor informal (especialmente devido à não separação entre trabalho e capital).

Neste sentido, é interessante notar como se torna possível a existência e convivência do setor informal junto a atividades tipicamente capitalistas, onde predomina o assalariamento e a contínua renovação tecnológica. Ora, a expansão e a dinâmica capitalistas, além de criarem ocupações no setor formal, permitem que funcionem, em seus interstícios, atividades as mais diversas, as quais cumprem uma função econômica. Demandas localizadas, áreas de baixa renda e atividades de pequeno alcance econômico são exemplos do espaço que pouco ou nada interessa ao setor formal, o qual é constituído, geralmente, por unidades maiores. Continuamente, portanto, a dinâmica capitalista cria, transforma e também destrói espaços que são ocupados pela informalidade. Por este motivo, é grande a rotatividade das atividades informais, sempre subordinadas a alterações ocorridas no setor formal. Muitas vezes, a produção do segmento informal destina-se às unidades 
formais, revelando outra importante forma de convivência entre estes grandes agregados.

Por fim, esta seção estabelece uma necessária distinção, com a finalidade de completar a caracterização do setor informal e evitar confusões entre este e a economia não registrada, também denominada submersa ou subterrânea.

Em primeiro lugar, o que caracteriza a economia submersa é o fato de que suas atividades não são captadas pelas estatísticas oficiais de emprego, produção e comercialização, levando a uma subestimação desses agregados. O funcionamento ilegal é sua marca registrada. Como foi visto, esta não é de forma alguma a principal "qualidade" da economia informal, embora possa ocorrer com certa frequência.

A regulação excessiva das atividades por parte do Estado, e também a existência de pesada carga tributária contribui para a ocorrência da economia submersa, embora nem sempre sejam estes os motivos principais. De qualquer forma, uma vez que estes fatores se façam presentes, junto a uma ausência de moralidade fiscal, ocorre um incentivo "natural" ao fortalecimento da economia subterrânea.

A ilegalidade independe do tamanho do empreendimento para que se faça presente. Quaisquer que sejam a escala e o aporte de capital, a empresa capitalista pode funcionar parcialmente na economia submersa, realizando operações de sub e super faturamento nas vendas e compras; utilizando parte da mão-de-obra sem registro legal; comprando equipamentos parcial ou totalmente contrabandeados e assim por diante.

Já o setor informal origina-se da dinâmica capitalista, a qual cria interstícios permanentes, embora em constante mutação. Uma vez que o produtor informal alcance estabilidade no negócio e no mercado em que atua, a tendência é de legalizar sua atividade, pela necessidade de fugir das multas do fisco e das propinas ao mesmo, fornecer notas de venda ou de serviços, 
contratar ajudantes por tempo mais prolongado, sem correr risco de sanções por parte da justiça trabalhista etc. Políticas de suporte ao setor informal, portanto, podem contribuir, a médio prazo, para um aumento na proporção de empresas que operam na economia registrada.

Neste sentido, a ilegalidade é uma característica presente no setor informal, mas que não chega a ser essencial. O Quadro 1, de forma simples, relaciona os setores formal/informal com as economias registrada/submersa.

\section{Quadro 1}

Inserção dos Trabalhadores Segundo os Setores Formal e Informal e as Economias Registrada e Submersa

\begin{tabular}{lll}
\hline \multirow{2}{*}{$\begin{array}{ll}\text { RELAÇÕES } \\
\text { DE PRODUÇÃO }\end{array}$} & $\begin{array}{l}\text { REONOMIA } \\
\text { REGISTRADA }\end{array}$ & $\begin{array}{l}\text { ECONOMIA } \\
\text { SUBMERSA }\end{array}$ \\
\hline \multirow{2}{*}{$\begin{array}{ll}\text { Setor } \\
\text { Formal }\end{array}$} & Assalariados registrados & Assalariados \\
& e Funcionários Públicos & não registrados \\
Setor & Pequenos produtores, & Pequenos produtores, \\
Informal & mão-de-obra familiar e & mão-de-obra familiar e \\
& ajudantes; Trabalhadores & ajudantes; Trabalhadores \\
por conta própria e & por conta própria e \\
& $\begin{array}{l}\text { ajudantes; Serviço } \\
\text { doméstico }\end{array}$ & $\begin{array}{l}\text { ajudantes; Serviço } \\
\text { doméstico }\end{array}$ \\
& (registrados) & (não registrados) \\
\hline
\end{tabular}

Fonte: CACCIAMALI (1989b, p.613)

Este quadro nos mostra que os pequenos produtores, mão-de-obra familiar, trabalhadores por conta própria e serviço doméstico, categorias pertencentes ao setor informal, podem fazer parte tanto da economia registrada 
como da economia submersa. Mesmo os assalariados do setor formal podem se encontrar na economia legalizada ou não, sendo também consenso que a parte mais representativa se encontra na economia registrada.

Estabelecidas estas diferenciações, fica claro que as propostas de política econômica devem ser diversas para estas duas abordagens. Já realizamos uma breve discussão acerca de políticas pertinentes ao setor informal. Elas se situam no âmbito da política social do Estado, tendo como objetivo diminuir as desigualdades sociais e de renda. Quanto à economia submersa, algumas medidas que poderiam contribuir para diminuir sua ocorrência situam-se no campo da desregulação da economia, num contexto de presença excessiva do Estado, especialmente na área tributária. Um maior poder de fiscalização também contribuiria no mesmo sentido.

\section{2 - Metodologia de Mensuração: Conceitos Básicos}

A primeira observação trata da distinção entre os conceitos de Salário e Rendimentos do Trabalho. Quando se fala em remuneração dos assalariados, pressupõe-se 0 estabelecimento de relações trabalhistas assentadas no assalariamento, seja com registro oficial ou não. A categoria Rendimentos do Trabalho reporta-se a uma definição mais ampla, dependendo do que seja definido como trabalho. Exemplificando, a própria Fundação IBGE, tanto no Censo Demográfico como na Pesquisa Nacional por Amostra de Domicílios (PNAD), considera como renda do trabalho não somente a parcela destinada aos empregados, como também a renda dos trabalhadores por conta-própria e até mesmo a renda dos empregadores. Ou seja, para a Fundação IBGE, a função do capitalista (dono ou gerenciador do empreendimento) é também considerada trabalho, no mesmo sentido dos trabalhadores assalariados. Como resultado, pelos dados da PNAD a parcela referente aos Rendimentos 
do Trabalho sempre ocupa em torno de $90 \%$ da renda total. Não se discute aqui a validade de tal interpretação, que seria fonte para um debate acerca da divisão entre trabalho e capital.

A relação Participação dos Salários na Renda aparece nas Contas Nacionais na divisão do Produto ou Renda Nacional, divisão esta que é também denominada distribuição da Renda Primária: uma parte referente à Remuneração dos Empregados (ou Assalariados) e um saldo, chamado Excedente Operacional Bruto. A primeira compreende "todos os pagamentos realizados pelos produtores em forma de salários e ordenados a seus empregados, tanto em espécie como em dinheiro, assim como todos os encargos sociais pagos pelo empregador, tais como: contribuição à previdência social, às caixas privadas de pensão, seguro-saúde etc. Estão incluídos neste fluxo as comissões, gratificações, abonos, pagamentos por dispensa, doença e quaisquer outros pagamentos efetuados pelo empregador, exceto os reembolsos feitos aos empregados por viagens, diárias e outros gastos incorridos ao realizar atividades por conta de seus empregadores." (Estatísticas Históricas do Brasil, IBGE, 1990, p.90). O saldo remanescente, que é o Excedente Operacional Bruto, é definido, dentro de um periodo contábil, "como a diferença entre o Valor Adicionado pelos produtores residentes e a soma da Remuneração dos Empregados e dos Impostos Indiretos (líquidos dos Subsídios), relativos ao mesmo periodo." (p.91). O Excedente Operacional, portanto, é obtido de forma residual a partir do Valor Adicionado.

A Fundação IBGE tem conceituação ampla no que se refere à classificação dos empregados: "todas as pessoas ocupadas nas Atividades Mercantis, Administrações Públicas, Sociedades sem Fins Lucrativos e Serviços Domésticos Remunerados." (p.90).

Uma vez de posse do valor da Remuneração dos Assalariados, a participação em relação à renda é obtida pela simples divisão daquele 
montante pelo total da Renda Interna a Custo de Fatores, ou seja, excluindo impostos líquidos (impostos menos subsídios). Deve-se ressaltar, entretanto, que apenas nos anos com disponibilidade de informações censitárias, especificamente 1970, 1975, 1980 e 1985, o SCNC (Sistema de Contas Nacionais Consolidado) faz estimativas para a categoria Remuneração dos Assalariados. Os dados acerca da relação em questão podem ser vistos na Tabela 5, reproduzida do texto de GÓES (1992).

Tabela 5

Participação dos Salários na Renda - Brasil

\begin{tabular}{cc}
\hline Anos & \% Remuneração dos Assalariados/Renda Interna, a C.F. \\
\hline 1970 & $40,7 \%$ \\
1975 & $36,5 \%$ \\
1980 & $38,7 \%$ \\
1985 & $39,9 \%$ \\
\hline
\end{tabular}

Fonte : IBGE, Contas Nacionais Consolidadas - 1980-1990, 1991 IBGE, Estatísticas Históricas do Brasil, 1990

Preliminarmente, pode-se levantar fatores que guardam relação com uma maior ou menor remuneração dos assalariados na renda. $A$ taxa média de remuneração salarial do setor ou indústria reflete a participação dos salários nas unidades produtivas. Outros fatores, como a maior ou menor participação dos assalariados na força de trabalho, a forma de organização da produção e o peso das contribuições sociais também afetam a relação em questão. As diferentes incidências destes elementos, seja entre as diversas atividades num país, seja entre países diferentes, redundam em participações diferentes dos salários na renda (Góes, 1992, p.3).

Sabe-se que a estrutura de contribuições sociais é especifica de cada país, onde tanto a extensão da seguridade social quanto sua forma de financiamento têm a ver com o aparato institucional vigente. No Brasil, é 
conhecido o fato de que a diferença entre o salário efetivamente pago ao empregado e a despesa total incorrida pelo empregador em relação à força de trabalho é bem maior que nos demais paises. Embora as Contas Nacionais permitam diferenciar os salários Brutos das Contribuições Sociais, as comparações internacionais são feitas com base na Remuneração dos Assalariados, a qual, como definida pela Fundação IBGE, considera as contribuições como parte dos salários. Assim, este fator contribui para "inflar" a participação dos salários na renda nacional.

A participação dos assalariados na força de trabalho e a forma de organização da produção têm um grande peso na diferenciação das economias nacionais. Quando as atividades são organizadas em unidades produtivas individuais, como microempresas, trabalhadores autônomos, pequenos estabelecimentos agrícolas, onde é alta a incidência de trabalho não assalariado, baixa relação salários/renda se manifesta, devida ao fato de que a renda desta categoria de trabalho fica contabilizada no Excedente Operacional Bruto.

Na seção 2.1, o presente trabalho esteve ocupado em esclarecer a estrutura e a dinâmica do mercado de trabalho brasileiro, pois há estreita ligação entre este e a distribuição funcional da renda, em especial na determinação da participação salarial. Foram vistos diversos fatores que contribuem para uma baixa participação dos salários no total da renda interna, entre os quais o rebaixamento dos mesmos em épocas recessivas, por mecanismos institucionais ou como forma de ajuste para evitar maior desemprego; participação relativamente alta, embora declinante ao longo do tempo, do setor primário na distribuição da população economicamente ativa, onde ocorre com maior frequência o trabalho não assalariado; alta relação capital/trabalho no setor que mais se expandiu no país no pós-guerra: o industrial, fruto do desenvolvimento tecnológico a nivel dos países centrais; índice significativo de participação do setor informal na economia, sabendo que 
grande parte deste segmento opera na economia submersa, a qual inclui também fração não desprezivel de atividades praticadas por empresas do setor formal, que buscam fugir do controle governamental e/ou da tributação excessiva.

O valor da "participação dos salários na renda", apresentado na tabela 5, não pode ser confundido com "participação do trabalho na renda nacional". Isso corresponde a considerar todo o Excedente Operacional Bruto como remuneração do Capital e da Terra, esquecendo que aí está incluída a remuneração dos autônomos e de grande parte do trabalho informal.

\section{3 - Os Avanços na Mensuração da Participação dos Assalariados na Renda}

Seria desejável poder contar com um instrumental analítico mais preciso, nas Contas Nacionais, para estimar uma participação dos assalariados na renda que se traduza em maior aproximação à realidade. A divulgação do índice de $38,0 \%$ para 1988 , somada às informações disponíveis para mensuração do agregado nos anos censitários a partir de 1970, as quais revelam alto grau de agregação, direcionaram este estudo numa tentativa de levantar fatores que pudessem explicar razoavelmente o comportamento dos percentuais apresentados.

Assim, a notícia de que a Fundação IBGE está em pleno processo de aperfeiçoamento de suas Contas Nacionais é bastante oportuna. Desde meados de 1985, quando ainda era de responsabilidade da FGV a preparação das Contas, esteve o IBGE iniciando "a implementação de programa para o desenvolvimento de um sistema de produção de séries anuais de Contas Nacionais completas para a economia brasileira, dentro de sua concepção atualizada." (Estatísticas Históricas do Brasil , IBGE, 1990). Estas últimas palavras - concepção atualizada - remetem-nos à conclusão de que já havia, 
em outras nações, sistema de Contas Nacionais com características diversas às encontradas na concepção doméstica.

De fato, já em 1968 é divulgada a revisão 3 do sistema de Contas Nacionais das Nações Unidas (System of National Accounts - SNA - rev.3), a qual incorporava progressos alcançados pelos países mais avançados no sentido de passar de uma postura tradicional na maneira de mensurar os agregados macroeconômicos e apresentá-los em contas consolidadas para a construção de um sistema amplo e articulado de informações, que descrevesse os processos econômicos subjacentes.

Em que pese o atraso relativo no início da implementação de um sistema - já batizado de Novo Sistema de Contas Nacionais (NSCN) -, esta nova forma de mensuração e apresentação dos dados deve incorporar aperfeiçoamentos desenvolvidos em nível internacional pós-revisão 3. O NSCN apóia-se na experiência anterior do IBGE no que se refere à elaboração das Matrizes de Relações Intersetoriais (MRI) de 1970, 1975 e 1980.

Os resultados são apresentados a seguir, destacando que os dados para 1970 e 1975 são mostrados na nova sistemática graças à possibilidade de aproximação entre a Matriz de Relações Intersetoriais (MRI) e o Novo Sistema de Contas Nacionais (NSCN). A comparabilidade entre ambos é comprometida em virtude de dois "desvios": nas MRI's o conceito de produção é mais restrito, por excluir atividades não mercantis e por captar as atividades informais com menor intensidade; a diferença mais importante, contudo, reside na exclusão, nas MRl's, das atividades das Administrações Públicas (APU's) no cômputo da Renda Interna. A partir de informações sobre despesas com mãode-obra e encargos das APU's, é possível tornar comparáveis dados oriundos das MRI's com os do NSCN.

Lembrando os dados apresentados acima, na Tabela 5, das Contas Consolidadas, e comparando-os com os resultados contidos na Tabela 8 , coluna "Conceito Amplo de Produção" do Novo Sistema, chama a atenção a 
diferença de patamar entre ambos. Naquela, os valores da participação dos assalariados na renda são os seguintes: $1970-40,7 \%$; $1975-36,5 \%$; 1980 $38,7 \%$ e 1985 - 39,9\%. A ocorrência de tal discrepância deve-se tanto à Remuneração dos Assalariados, a qual é $12 \%$ mais baixa nas Contas Consolidadas, como da Renda, sendo $6 \%$ mais alta na mesma fonte. Esta última diferença, a que ocorre na medida da Renda, poderia ser ainda maior, caso não atuassem em direção oposta diversos fatores relacionados à metodologia de mensuração em cada sistema.

\section{Tabela 6 \\ PARTICIPAÇÃO DOS SALÁRIOS NA RENDA \\ Brasil}

\% Remuneração dos Assalariados/Renda Interna, a C.F.

Fonte

Conceito Restrito de Produção

Conceito Amplo de

Produção

(MRI)

(CONTAS NACIONAIS)

\begin{tabular}{ccc}
\hline MRI-70 & $41,2 \%$ & $47,5 \%^{* *}$ \\
MRI-75 & $35,6 \%$ & $41,7 \%^{* *}$ \\
NSCN-80 & $41,4 \%^{*}$ & $47,9 \%$ \\
NSCN-81 & $44,1 \%^{*}$ & $49,9 \%$ \\
NSCN-82 & $46,5 \%^{*}$ & $52,2 \%$ \\
NSCN-83 & $42,8 \%^{*}$ & $48,9 \%$ \\
NSCN-84 & $37,7 \%^{*}$ & $43,5 \%$ \\
NSCN-85 & $40,2 \%^{*}$ & $46,8 \%$ \\
\hline
\end{tabular}

Fonte: IBGE, Matriz de Relações Intersetoriais - Brasil 1970

IBGE, Matriz de Relações Intersetoriais - Brasil 1975

IBGE, Novo Sistema de Contas Nacionais 1980-1985

Resultados Provisórios, em GÓES (1992)

* Excluindo Administrações Públicas

** Incluindo Administrações Públicas

Pelo lado da Remuneração dos Assalariados, a inclusão de elementos não considerados nas Contas Consolidadas, como salários e contribuições 
sociais nos estabelecimentos-sede das empresas levantadas pelos Censos mas não divulgados nas respectivas publicações, bem como a conceituação mais restrita de contribuição social paga pelas APU's e menor extensão das estimativas de assalariados sem vínculo formal no sistema tradicional, resultam em um maior agregado no NSCN (GÓES, 1992, p.9).

Pelo conceito restrito de produção das MRI's, excluem-se as APU's a partir de 80 em virtude de que a fonte dos dados é o Novo Sistema, a fim de tornar possível a verificação da trajetória do agregado no decorrer do tempo.

Como esperado, as contrações e expansões são no mesmo sentido, seja no conceito mais amplo ou mais restrito de produção focalizado. Interessa particularizar a análise no conceito amplo das Contas Nacionais, pois em última análise é o percentual decorrente deste método que vale para comparações internacionais. Destaca-se o alto grau de variabilidade do agregado, sem apresentar tendência definida. Certamente isto reflete a instabilidade presente na economia brasileira. Por um lado, há os efeitos dos fatores de ordem institucional, relacionados às variadas intervenções e alterações de normas de política salarial; por outro, é necessário considerar os efeitos dos ajustes do início da década de oitenta, somados ao processo de inflação crescente.

Em nível mundial, a relação participação dos salários na renda tem comportamento muito mais estável nas diversas economias nacionais, fato revelado pela Tabela 7 . 


\section{Tabela 7}

Comparações Internacionais - Participação dos Salários

\% Remuneração Assalariados/Renda Interna

1970

1988

E.U.A.

$67,2 \%$

$65,5 \%$

Japão

$46,2 \%$

$59,5 \%$

Alemanha

$60,0 \%$

$59,0 \%$

França

$56,7 \%$

$59,9 \%$

Itália

$49,8 \%$

$49,2 \%$

Inglaterra

$58,9 \%$

$63,3 \%$

Espanha

$48,6 \%$

$49,9 \%$

Austrália

$59,2 \%$

$55,8 \%$

Chile

$47,7 \%$

$48,0 \%$ (1982)

México

$37,4 \%$

$29,4 \%(1987)$

Coréia

$37,2 \%$

$45,0 \%$

Fonte: ONU, National Accounts Statistics - 1988, 1990, em GÓES (1992).

É certo que, seguindo o mesmo raciocínio, a estabilidade do agregado é reflexo da estabilidade das diversas economias. Tomando os países adiantados, incluindo Espanha e Austrália, nota-se relativa estabilidade do agregado entre 1970 e 1988 nos Estados Unidos, Alemanha, Itália e Espanha. O Japão apresenta extraordinário crescimento da participação salarial na renda, e a França um aumento bastante pequeno. Na Inglaterra e na Austrália, diminui a participação dos salários, sendo este comportamento mais intenso na primeira nação. Para os três últimos países da tabela, estão presentes as três tendências: estabilidade no Chile, queda significativa no México e crescimento, também significativo, na Coréia.

Além da trajetória ao longo do tempo, é interessante observar que, em relação às economias desenvolvidas, a participação dos salários na renda no Brasil, que, em média, se situa na faixa dos $48 \%$ entre 1970 e 1985 (conforme - NSCN e lembrando que são resultados provisórios), ainda é baixa. Estas 
divergências apenas revelam as disparidades na estrutura econômica do país relativamente às economias maduras. Reforçando esta afirmação, economias que guardam maiores semelhanças com a brasileira, caso do México, Chile e Coréia, bem como de economias desenvolvidas mas com mercado de trabalho urbano com maior participação de trabalhadores independentes, caso da Itália e Espanha, mostram uma participação dos assalariados na renda bastante próxima à da economia nacional ou até substancialmente mais baixa.

O Novo Sistema de Contas Nacionais permite a desagregação do índice participação dos salários na renda, enriquecendo a análise da estrutura da economia brasileira. Combinando as informações das tabelas 8 e 9 , a seguir, vemos que, das atividades produtivas com maior peso na composição da ocupação, a indústria de transformação é a que apresenta uma variação claramente declinante. Notando que a queda se manifesta a partir de 1983 e que esta atividade tem alto índice de assalariamento $(91,1 \%)$, com a quase totalidade $(88,8 \%)$ mantendo vínculo formal, chegamos à conclusão de que a política de subindexação salarial, que provocou forte contração dos salários reais em 1984, atingiu em cheio os rendimentos dos trabalhadores da indústria de transformação. A recessão também afetou o desempenho do setor, tendo havido cortes drásticos de pessoal entre 1981 e 1983, de maneira que a recuperação de 84/85 não conseguiu repor totalmente o nível de emprego que havia em 1980. 
Tabela 8

Participação dos Salários na Renda por Atividade Produtiva

\begin{tabular}{lcccccc}
\hline & \multicolumn{5}{c}{ \% Remuneração dos Assalariados/Renda } \\
\hline Agropecuária & 1980 & 1981 & 1982 & 1983 & 1984 & 1985 \\
Extração Mineral & $19,5 \%$ & $21,4 \%$ & $26,2 \%$ & $17,9 \%$ & $18,9 \%$ & $20,5 \%$ \\
Ind.Transformação & $27,8 \%$ & $33,5 \%$ & $33,8 \%$ & $27,4 \%$ & $23,6 \%$ & $29,4 \%$ \\
Construção Civil & $46,5 \%$ & $44,9 \%$ & $45,3 \%$ & $40,2 \%$ & $32,3 \%$ & $33,4 \%$ \\
Energia Elétrica & $55,3 \%$ & $48,7 \%$ & $49,1 \%$ & $40,9 \%$ & $39,4 \%$ & $45,9 \%$ \\
Comércio & $55,0 \%$ & $35,9 \%$ & $35,0 \%$ & $34,8 \%$ & $32,9 \%$ & $31,9 \%$ \\
Transporte & $42,9 \%$ & $43,0 \%$ & $45,4 \%$ & $41,6 \%$ & $39,3 \%$ & $44,3 \%$ \\
Comunicações & $56,9 \%$ & $52,5 \%$ & $48,2 \%$ & $54,9 \%$ & $35,4 \%$ & $41,9 \%$ \\
Otrs.Servs.Mercant & $28,6 \%$ & $30,6 \%$ & $31,5 \%$ & $29,6 \%$ & $32,0 \%$ & $36,1 \%$ \\
Inst.Financeiras & $39,7 \%$ & $38,1 \%$ & $38,2 \%$ & $24,3 \%$ & $18,6 \%$ & $21,8 \%$ \\
Adm.Públicas & $100,0 \%$ & $100,0 \%$ & $100,0 \%$ & $100,0 \%$ & $100,0 \%$ & $100,0 \%$ \\
Serv.não mercantis & $100,0 \%$ & $99,6 \%$ & $52,3 \%$ & $100,8 \%$ & $98,3 \%$ & $106,3 \%$ \\
TOTAL & $47,9 \%$ & $49,9 \%$ & $52,2 \%$ & $48,9 \%$ & $43,5 \%$ & $46,8 \%$ \\
URBANO & $51,5 \%$ & $53,3 \%$ & $54,8 \%$ & $52,9 \%$ & $46,6 \%$ & $50,1 \%$ \\
\hline
\end{tabular}

Fonte: IBGE, Novo Sistema de Contas Nacionais

Resultados Provisórios, em GÓES (1992) 
Tabela 9

Composição da Ocupação por Atividade Produtiva em 1980

\begin{tabular}{lcccc}
\hline & $\begin{array}{c}\text { Partic.Ocup } \\
\text { dos no }\end{array}$ & $\begin{array}{c}\text { Partic.Assal } \\
\text { riados no }\end{array}$ & $\begin{array}{c}\text { Partic.Assal } \\
\text { na }\end{array}$ & $\begin{array}{c}\text { Assalar. - \% } \\
\text { Vinc.Formal }\end{array}$ \\
\hline Aaropecuária & $34.5 \%$ & $20.4 \%$ & $37.5 \%$ & $0.4 \%$ \\
Extração Mineral & $0,7 \%$ & $0,6 \%$ & $55,2 \%$ & $39,2 \%$ \\
Indústria Transformação & $13,6 \%$ & $19,7 \%$ & $91,1 \%$ & $88,8 \%$ \\
Construção Civil & $8,1 \%$ & $9,2 \%$ & $71,4 \%$ & $39,4 \%$ \\
Energia Elétrica & $0,6 \%$ & $0,9 \%$ & $100,0 \%$ & $100,0 \%$ \\
Comércio & $8,6 \%$ & $7,0 \%$ & $52,0 \%$ & $49,7 \%$ \\
Transporte & $3,6 \%$ & $3,8 \%$ & $66,9 \%$ & $53,8 \%$ \\
Comunicação & $0,4 \%$ & $0,6 \%$ & $100,0 \%$ & $100,0 \%$ \\
Instituições Financeiras & $1,7 \%$ & $2,6 \%$ & $97,2 \%$ & $97,2 \%$ \\
Outros Servs.Mercantis & $13,1 \%$ & $11,4 \%$ & $55,1 \%$ & $44,2 \%$ \\
Set.Privado não Mercantis & $6,4 \%$ & $10,1 \%$ & $99,3 \%$ & $41,0 \%$ \\
Administrações Públicas & $8,6 \%$ & $13,7 \%$ & $100,0 \%$ & $100,0 \%$ \\
Total Urbano & $65,4 \%$ & $79,6 \%$ & $76,9 \%$ & $63,4 \%$ \\
Total Geral & $100,0 \%$ & $100,0 \%$ & $63,3 \%$ & $41,6 \%$ \\
\hline Fonte: & &
\end{tabular}

Fonte: IBGE, Novo Sistema de Contas Nacionais - Ano-Base 1980 (1988)

Resultados Provisórios, em GÓES (1992)

O peso da Indústria de Transformação no desempenho da relação salários/renda é constatado pelo seguinte fato: excluindo esse setor, a participação salarial global aumentaria de 48,5\% em 1980 para 53\% em 1985. Aliás, para que essa participação no agregado se mantivesse praticamente inalterada, estiveram colaborando o desempenho das Administrações Públicas e dos Outros Serviços Mercantis. No caso das primeiras, devido à sua expansão na ocupação total: de $8,6 \%$ em 1980 , passa a $11,1 \%$ em 1985 . Os gastos das Administrações Públicas compõem-se exclusivamente de salários e contribuições sociais, de forma que qualquer aumento na participação da atividade redunda em incremento da relação global participação dos salários na renda nacional. Já no caso dos Outros Serviços Mercantis, ocorre aumento da própria relação na atividade. Este incremento exerce influência limitada no 
agregado global em virtude do baixo nivel de assalariamento: $55,1 \%$, dos quais apenas $44,2 \%$ tem vínculo formal.

Junto com a atividade Outros Serviços Mercantis, as que apresentam baixo coeficiente de assalariamento são a Agropecuária, com $37,5 \%$ de assalariados no total ocupado pelo ramo, com praticamente inexistência de vinculação formal, e o comércio, com $52,0 \%$ de mão-de-obra assalariada, sendo a metade $(49,7 \%)$ com carteira assinada. Estas características exercem alto grau de influência na determinação da participação dos assalariados na renda. Voltando a atenção à Tabela 8 , para o ano de 1980 , nota-se que estas três atividades, mais a de Extração Mineral, são as que apresentam os menores coeficientes: $28,6 \%, 19,5 \%, 35,0 \%$ e $27,8 \%$, respectivamente, em 1980.

Uma outra forma de tratar a questão da participação salarial na renda refere-se à própria composição da renda nos diversos setores institucionais. As Tabelas 12 e 13 fornecem maiores detalhes neste sentido.

A Tabela 10 contém 6 colunas com índices percentuais. Para melhor compreendê-la, caminhando a partir da esquerda, temos que a soma da primeira coluna com a última resulta na totalidade da Renda Nacional. A segunda coluna é decomposta nas terceira e quarta. Por fim, a soma da segunda com a quinta corresponde aos percentuais da primeira coluna. 


\section{Tabela 10}

Composição da Renda nos Setores Institucionais - Brasil: 1980

\begin{tabular}{|c|c|c|c|c|c|c|}
\hline & \multicolumn{5}{|c|}{ Remuneração dos Assalariados } & \multirow{3}{*}{$\begin{array}{l}\text { Exc. Oper } \\
\text { Bruto (f) } \\
a+f=100 \%\end{array}$} \\
\hline & \multirow{2}{*}{$\begin{array}{c}\text { Total } \\
a=(b+e)\end{array}$} & \multicolumn{3}{|c|}{ Salário } & \multirow{2}{*}{$\begin{array}{c}\text { Contrib. } \\
\text { Sociais } \\
\mathrm{e} \\
\end{array}$} & \\
\hline & & $\begin{array}{c}\text { Total } \\
b=(c+d)\end{array}$ & $\begin{array}{c}\text { CNinc. } \\
c\end{array}$ & $\begin{array}{c}\text { SNinc. } \\
\text { d }\end{array}$ & & \\
\hline Total & $48,0 \%$ & $38,4 \%$ & $34,0 \%$ & $4,4 \%$ & $9,6 \%$ & $52,0 \%$ \\
\hline Empresas Não Fin. & $50,3 \%$ & $39,2 \%$ & $39,2 \%$ & & $11,1 \%$ & $49,7 \%$ \\
\hline Inst.Financeiras & $40,0 \%$ & $30,7 \%$ & $30,7 \%$ & & $9,3 \%$ & $60,0 \%$ \\
\hline Adm.Públicas & $97,0 \%$ & $72,0 \%$ & $72,0 \%$ & & $25,0 \%$ & $3,0 \%$ \\
\hline Família Total & $24,8 \%$ & $22,9 \%$ & $12,7 \%$ & $10,2 \%$ & $1,9 \%$ & $75,2 \%$ \\
\hline Alug.+Serv.Dom. & $9,6 \%$ & $9,0 \%$ & $8,4 \%$ & $0,6 \%$ & $0,6 \%$ & $90,3 \%$ \\
\hline Micro+Autônoms. & $28,4 \%$ & $26,2 \%$ & $14,7 \%$ & $11,5 \%$ & $2,2 \%$ & $71,6 \%$ \\
\hline Agropecuária & $18,8 \%$ & $18,8 \%$ & $0,2 \%$ & $18,6 \%$ & & $81,2 \%$ \\
\hline Educ.+Saúde & $51,8 \%$ & $42,8 \%$ & $42,8 \%$ & & $9,0 \%$ & $48,2 \%$ \\
\hline Inst.Priv.s/Fins Lc & $99,9 \%$ & $91,9 \%$ & $82,2 \%$ & $9,7 \%$ & $8,0 \%$ & $0,1 \%$ \\
\hline
\end{tabular}

Fonte: IBGE, Novo Sistema de Contas Nacionais- Ano-Base 1980 (1988)

Resultados Provisórios, em GÓES (1992)

Em 1980, a remuneração dos assalariados correspondia a $48,0 \%$ da Renda Total e o excedente operacional bruto representava $52,0 \%$. Além de características já ressaltadas, como a massiva participação de assalariados nas APU's, estas últimas tabelas trazem uma informação importante: a diferenciação setorial por tamanho do empreendimento. É o que ocorre no caso das Empresas não Financeiras, as quais excluem microempresas. Nota-se que nas primeiras, é muito maior a remuneração dos assalariados: $50,3 \%$ contra $28,4 \%$ nas microunidades e nos autônomos. Conforme destacado em seção 
anterior, as microempresas e o trabalho por conta própria são típicos do setor informal, e apresentam baixo coeficiente de assalariamento e registro. Além do mais, como pode ser constatado, as atividades com características de maior formalidade apresentam maior nivel de contribuições sociais, que entram no cômputo da remuneração dos assalariados.

\section{Tabela 11}

Composição da Ocupação por Setor Institucional - Brasil: 1980

\begin{tabular}{l|c|c|c|c}
\hline & $\begin{array}{l}\text { Pessoal Ocu } \\
\text { pado Total. }\end{array}$ & $\begin{array}{l}\text { Assalari- } \\
\text { ados }\end{array}$ & $\begin{array}{l}\text { Assalar. - } \% \\
\text { Ocup.Total }\end{array}$ & $\begin{array}{l}\text { Assalar. - \% } \\
\text { Vinc.Formal }\end{array}$ \\
\hline Total & $100,0 \%$ & $100,0 \%$ & $63,3 \%$ & $65,8 \%$ \\
Empresas não Financeiras & $20,6 \%$ & $28,2 \%$ & $86,7 \%$ & $99,3 \%$ \\
& & & & \\
Instituições Financeiras & $1,7 \%$ & $2,6 \%$ & $99,5 \%$ & $100,0 \%$ \\
& & & & \\
Administrações Públicas & $8,6 \%$ & $13,7 \%$ & $100,0 \%$ & $100,0 \%$ \\
& & & & \\
Família Total & $69,1 \%$ & $55,5 \%$ & $50,9 \%$ & $38,8 \%$ \\
Aluguéis + Serv.Domést. & $5,8 \%$ & $9,1 \%$ & $100,0 \%$ & $36,7 \%$ \\
Micro + Autônomos & $26,1 \%$ & $22,3 \%$ & $54,0 \%$ & $64,7 \%$ \\
Agropecuária & $34,5 \%$ & $20,5 \%$ & $37,5 \%$ & $1,0 \%$ \\
Educação + Saúde & $2,1 \%$ & $2,8 \%$ & $84,2 \%$ & $100,0 \%$ \\
Inst.Priv.s/fins lucrativos & $0,7 \%$ & $1,0 \%$ & $93,2 \%$ & $85,4 \%$ \\
\hline Fonte:IBGE, Novo Sistom
\end{tabular}

Fonte: IBGE, Novo Sistema de Contas Nacionais - Ano-Base 1980 (1988)

Resultados Provisórios, em GÓES (1992)

Assim, não faz sentido tomar o indice de participação dos assalariados como referência para a contraposição capital/trabalho em atividades cuja renda tenha em sua composição pequena contribuição de trabalho assalariado, como é o caso das microempresas. 
A esse respeito, um outro avanço está em andamento no que se refere à mensuração da participação dos salários na renda: a classificação do Excedente Operacional Bruto das unidades produtivas individuais numa categoria especifica: rendimento misto trabalho/capital. Na verdade, trata-se da retomada de prática adotada nas Contas Nacionais da FGV antes de 1964, que fazia a classificação. De qualquer forma, essa prática colaborará para proporcionar maior conhecimento da distribuição funcional da renda no Brasil. Estimativas nesta nova conceituação para 1980 revelam que aproximadamente $16 \%$ da renda pertence à remuneração trabalho/capital, $37 \%$ ao Excedente Operacional Bruto e cerca de $47 \%$ à participação dos salários.

Finalmente, retomando as comparações internacionais, e agora de posse de informações desagregadas, os seguintes fatores contribuem para uma menor participação dos salários na renda no Brasil em relação aos países desenvolvidos: maior peso das atividades agropecuárias na economia nacional, representando cerca de $11 \%$ do Valor Adicionado, ao passo que naquelas nações não passa de $3 \%$, e estrutura econômica com menor participação de atividades tipicamente capitalistas, o que se consubstancia num menor nível de assalariamento e maior abrangência de atividades informais. 


\section{3 - DISTRIBUIÇÃO DE RENDA NO BRASIL DESDE A DÉCADA DE 60}

Neste capítulo, estaremos tratando da distribuição pessoal da renda, buscando dar um panorama de seu comportamento nas últimas décadas. Sempre que possivel, será feita referència ao comportamento macroeconômico em seu papel, por um lado, como condicionante das variações na distribuição, e por outro, como sujeito à influência do perfil distributivo.

A distribuição pessoal da renda pode se referir tanto à repartição entre indivíduos como entre famílias. Quando falamos em distribuição de renda da população economicamente ativa, do pessoal ocupado, das pessoas de dez anos e mais, estamos nos referindo à repartição individual da renda. Neste caso, o interesse da análise reside em aspectos mais diretamente relacionados ao comportamento do mercado de trabalho, bem como no conhecimento da repartição da renda entre as diversas classes sociais, uma vez que os indivíduos que participam da geração de rendimentos o fazem nas funções de empregadores, trabalhadores assalariados e trabalhadores por conta própria. Os dados sobre a distribuição de renda entre famílias captam melhor as noções de riqueza e pobreza, uma vez que a renda familiar é que determina, de fato, o nivel de consumo das pessoas, que por sua vez se liga estreitamente ao nível de vida.

As fontes primárias de dados da distribuição pessoal são da Fundação IBGE, destacando-se os Censos Demográficos e as Pesquisas Nacionais por Amostra de Domicílios (PNADs). A PNAD é uma pesquisa anual, implantada a partir do segundo trimestre de 1967 (quando então sua periodicidade era 
trimestral, até o primeiro trimestre de 1970), não disponível em anos de Censo e nos anos de 1974, 1975 e 1994. No que se refere aos Censos, antes de 1872 há registros de estimativas populacionais regionais e gerais, que remontam ao Brasil Colônia (MEDICl, 1984, pp.75-76). A partir de 1872, até 1991, são realizados com intervalo aproximadamente decenal.

Pode-se pensar que a metodologia das duas pesquisas tenha tal semelhança que as tornem comparáveis em periodos próximos. Não é o que ocorre, infelizmente. No que se refere ao levantamento da renda junto aos entrevistados, nos Censos pergunta-se qual o rendimento médio nos últimos doze meses, caso os mesmos tenham sido variáveis (honorários de profissionais liberais, comissões de venda ou corretagens, pagamento pela prestação de serviços etc.); se fixos (salários, ordenados, vencimentos contratuais etc.), qual o rendimento recebido no mês anterior ao da pesquisa. Sabe-se que os rendimentos fixos são os predominantes, contudo não se pode desprezar a magnitude dos rendimentos variáveis. Na PNAD, pergunta-se qual - rendimento recebido na semana anterior à entrevista. Os meses de referência para as PNADs são agosto, setembro ou outubro. Portanto, as informações sobre rendimentos refletem essencialmente a conjuntura do mês de referência, ao passo que nos Censos a participação de rendas variáveis leva a que os dados apresentem o caráter de uma média anual, menos sujeitos a variações conjunturais.

No capitulo anterior tratou-se de estudar a distribuição funcional da renda desde a década de 40 . Isto foi possivel em virtude da disponibilidade de dados, expressos nas Contas Nacionais. Já neste capitulo, embora seja analisado o processo de industrialização e conformação do mercado interno no Brasil desde fins do século XIX, o estudo específico da distribuição de renda restringe-se ao período posterior a 1960, pois são escassas as informações em Censos anteriores. 
O primeiro Censo a coletar informações sobre rendimentos é o de 1890. Devido a inúmeras dificuldades, técnicas e administrativas, somente em 1900, às vésperas da realização do Segundo Censo da República, foi divulgado o último volume de informações do levantamento de 1890; aliás, não incluindo dados sobre renda. Ao que parece, o principal motivo da exclusão foi a má qualidade das informações relativas a esta variável, que correspondia a um alto percentual de não declaração ( $\mathrm{MEDICl}, 1984$, p.79). Há que se salientar o alto grau de dificuldade de coleta das informações sobre renda, sobretudo àquela época. Quase sempre se faz presente certo constrangimento e mesmo relutância por parte do entrevistado em divulgar seus rendimentos. Ademais, a economia brasileira era muito heterogênea até a Segunda Guerra Mundial, com presença significativa de formas pré-capitalistas de produção e remuneração convivendo com atividades baseadas no assalariamento. Dessa forma, é suspensa a coleta de informações sobre renda, a qual é retomada apenas em 1960, a partir de quando efetivamente ocorre também a divulgação desses dados.

Tanto na PNAD quanto no Censo os estratos de rendimento são definidos com base no salário mínimo. Na PNAD tais estratos têm limites inferiores iguais a $0,1,2,5,10$ e 20 salários mínimos, além dos sem rendimento e dos sem declaração de rendimentos. No Censo há dois estratos a mais, com limites inferiores iguais a 0,25 e 0,5 salário mínimo.

Limitações dos dados sobre rendimentos, comuns às duas pesquisas, referem-se à subdeclaração das rendas. Conforme HOFFMANN \& KAGEYAMA (1986, p.26), um primeiro tipo de limitação refere-se à subestimação da renda nos Censos decorrente da própria forma de coleta, através de questionários. Como visto no capitulo anterior, as Contas Nacionais apresentam estimativas da Renda, cujo valor, em princípio, deveria aproximar-se daquele estimado pelos Censos. Multiplicando por 12 o total da renda mensal deciarada pelas pessoas de 10 anos ou mais no Censo de 1980, o valor encontrado representa 
cerca de $60 \%$ da Renda Líquida Disponível no Setor Privado daquele mesmo ano, admitindo que esta seja a estimativa mais próxima da renda pessoal total (lembrar que as Contas Nacionais também estão sujeitas a erros de medição, porém acredita-se que sejam mais confiáveis, devido à diferente maneira de mensuração). Dado que o Consumo Pessoal, também das Contas Nacionais, representou mais de $85 \%$ da Renda Disponivel no Setor Privado, claro está que os lucros não distribuídos não podem dar conta da diferença apresentada, da ordem de $40 \%$.

Uma primeira explicação para a subestimação da renda nos Censos e nas PNADs é que não é computada a produção para autoconsumo. Trabalhadores rurais em sistema de produção familiar são os que mais consomem parte do produto gerado, parcela esta que deixa de ser avaliada. Por outro lado, pelo menos "teoricamente", a renda recebida em espécie por empregados rurais é computada. De qualquer modo, a participação da renda rural na renda total foi perdendo importância relativa, principalmente a partir da década de setenta, ao se consolidar o processo brasileiro de urbanização. Com isso, entretanto, relativiza-se também o problema da subestimação devida à não computação da produção destinada ao autoconsumo.

Outros casos de remuneração não monetária referem-se a altos funcionários de empresas, os quais costumeiramente recebem carro e combustivel para uso próprio, profissional ou pessoal, e uma série de outros benefícios. Outra limitação ligada à metodologia de pesquisa diz respeito ao não cômputo de benefícios, como o $13 .^{\circ}$ salário, que são pagos em meses diferentes ao do mês de referência, afetando, portanto, tanto os rendimentos declarados nas PNADs, como os rendimentos fixos dos Censos. Para o IBGE não há dúvida de que deveria ser computado $1 / 12$ do $13^{\circ}$ salário na remuneração declarada, dado que no Censo de 1980, na parte de "Conceituação", consta que deveria ser incluído $1 / 12$ do $14^{\circ}$ salário do PIS/PASEP. Entretanto, é improvável que isso tenha sido feito, dado que tanto 
o entrevistador quanto o entrevistado estão, em geral, com pressa de terminar o preenchimento do questionário.

O principal problema ligado à subestimação da renda, contudo, reside na subdeclaração das rendas altas. Os entrevistados dos estratos de altas rendas, além de obterem variadas receitas indiretas, apresentam tendência à subdeclaração de seus ganhos.

Problemas ligados à comparabilidade dos dados censitários são agora discutidos. Inicialmente, ao longo dos Censos de 60, 70 e 80, ocorreu progressivo aperfeiçoamento na coleta de informações relativas à renda.

Em 70, rendimentos tais como o soldo dos militares, pagamento de prestação de serviços, diferenças entre o preço de aquisição e o de venda para os praticantes de atividades mercantis, entre outros, passaram a ser computados, enquanto não foram explicitados no Censo de 60.

Em 80, o questionário revestiu-se de maior riqueza de detalhes, de forma a contribuir para um fornecimento mais preciso por parte do entrevistado dos valores sobre rendimento. $\mathrm{Na}$ ausência de outros fatores limitantes, portanto, acredita-se que os dados de Censos mais antigos estão mais sujeitos à subestimação.

Na esfera técnico-operacional, no Censo de 80 , há a possibilidade de os entrevistadores terem burlado o critério estabelecido, como forma de aumentar a produtividade de seus levantamentos (MEDICl, 1984. pp.95-96). É que há dois tipos de questionários: um mais completo, que deveria ter sido aplicado na sequência, por exemplo, de um domicílio para cada três entrevistados; e outro, mais simplificado, que deveria ter sido aplicado nos demais domicílios. Supõese que os recenseadores ajustaram a aplicação do questionário completo aos domicílios com menor número de pessoas, desrespeitando a sequência combinada previamente, fato que é confirmado pela inconsistência no número de pessoas por família na não-amostra (aquela relacionada ao questionário simplificado), muito maior que o número de pessoas por família na amostra. 


\section{1 - Industrialização no Brasil e Conformação do Mercado Interno}

O Brasil deixou, hoje, a desconfortável posição de líder no grau de desigualdade (ver Gráfico 6) entre os países que têm dados considerados confiáveis pelo Banco Mundial, mas continua em péssima posição. Quando este revelou aqueles dados, o indice de Gini para o Brasil era de 0,603, correspondente ao ano de 1993, único dentre todos os países que superava a casa dos 0,60 . Graças à persistência do processo de concentração de renda verificado nas últimas décadas, permanecera durante muitos anos como o pais de maior concentração de renda.

A estabilização de preços decorrente do Plano Real contribuiu para diminuir o grau de desigualdade, de forma que a Guatemala apresenta, agora, o maior índice de Gini mundial. Deve-se atentar, contudo, que os dados para os demais países que não o Brasil são mais desatualizados.

\section{Gráfico 6}

Os Dez Países Mais Desiguais - Índice de Gini

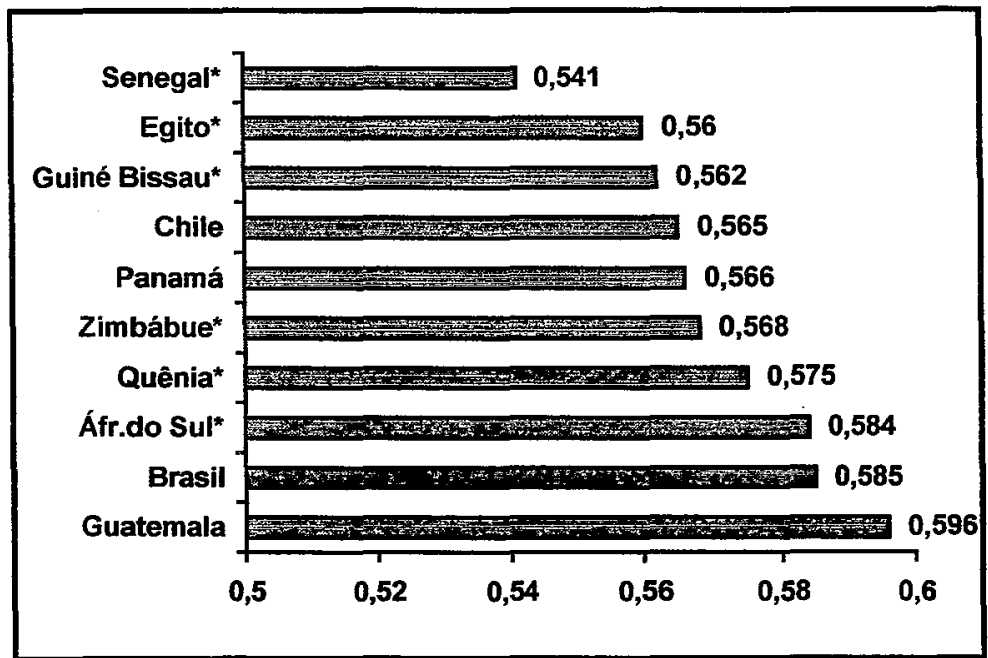

\begin{tabular}{|c|c|c|c|}
\hline Pais & $\begin{array}{c}\text { Ano da } \\
\text { pesquisa }\end{array}$ & $\begin{array}{c}\text { Renda } \\
40 \%+ \\
\text { pobres } \\
(\%)\end{array}$ & $\begin{array}{c}\text { Renda } \\
10 \%+ \\
\text { ricos } \\
(\%)\end{array}$ \\
\hline Senegal & 1991 & 10,5 & $-42,8$ \\
\hline Egito & $1986 / 7$ & 9,3 & 43,4 \\
\hline G.Bissau & 1991 & 86 & $42 ; 4$ \\
\hline Chile & 1994 & 10,1 & 46,1 \\
\hline Panamá & 1989 & 60 & 422 \\
\hline Zimbáb. & 1990 & 10,3 & 46,9 \\
\hline Quênia & 1992 & Whary & 477 \\
\hline Afr.Sul & 1993 & 9,1 & 47,3 \\
\hline Brasil & 1995 & rivof & 482 \\
\hline Guatem. & 1989 & 7,9 & 46,6 \\
\hline
\end{tabular}

Fonte: Banco Mundial (1996, pp.196/197)

* Dados se referem ao consumo, e não à renda. Desigualdade de consumo é, em geral, menor que a de renda. 
Em termos de América Latina, onde o Brasil possui o maior PIB, os indicadores sociais revelam deficiências no alcance do crescimento econômico verificado. A taxa de mortalidade infantil é cinco vezes maior que a do Chile; o grau de analfabetismo é quatro vezes maior que na Argentina e a esperança de vida dos brasileiros é quatro anos menor do que a dos mexicanos (BANCO MUNDIAL, 1996, pp.189,199,201).

A fim de tratar o problema com o destaque que merece, é necessário entender o caráter do desenvolvimento que teve lugar no país, buscar as raizes do processo de concentração da renda e percorrer o caminho que desemboca na crise dos anos 80 e 90 (sem a pretensão de realizar uma análise aprofundada desses temas).

Pode-se dividir a industrialização brasileira em três fases, a primeira compreendendo desde o fim do século passado até 1929, a segunda de 1930 a 1964 e a terceira de 1965 a 1979.

Na primeira fase, quando as principais nações da Era Moderna já tinham passado pela Revolução Industrial, o Brasil praticamente iniciou sua industrialização. Diferentemente dos processos iniciais sucedidos naquelas nações, não ocorreu a instalação "natural" de manufaturas, depois fábricas e inovações tecnológicas que se traduziriam em maior produtividade do trabalho. Quando o Brasil passou a contar com uma industrialização mais efetiva, em fins do século passado, devido ao atraso relativo na implantação dos processos capitalistas de organização da produção, não se apresentou outro caminho senão o de importação de "pacotes" industriais - quais sejam montagem de fábricas (principalmente de produção têxtil) com determinados tamanho e grau de tecnologia, ligados à chamada fase do capitalismo monopolista.

Esta primeira fase, contudo, não se caracteriza por forte industrialização, senão por investimentos esparsos, sem nenhuma ou com reduzida integração. 
A economia cafeeira era responsável, no fim do século passado, pelo desempenho da economia nacional. Foi o tempo da economia "primárioexportadora", dependente do comportamento da demanda externa. A notável expansão da cultura foi influenciada por dois fatores: quebra da produção asiática, devido à destruição dos cafezais da ilha de Ceilão, e instituição da descentralização republicana. Assim, o Brasil pôde dominar "três quartas partes da produção mundial", sob o impulso da autonomia dos governadores dos estados produtores (FURTADO, 1986, pp.177-178).

Havia, contudo, nos países produtores de café, caracteristicas que certamente levariam o preço do produto a declinar, no longo prazo: ampla oferta de mão-de-obra e abundância de terras disponiveis para plantio. Nestas condições, o crescimento da oferta chegaria em algum momento a empurrar para baixo o preço do café.

Assim, a depressão que atingiu fortemente os Estados Unidos, na década de 1890 , associada ao crescimento da oferta, levou a cotação da saca exportada de café, de 4,09 libras em 1893 para 1,48 libras em 1899. Como os estoques de café se avolumavam ano a ano, a solução encontrada pela oligarquia cafeeira foi a política de valorização do café, através da celebração do Acordo de Taubaté, em fevereiro de 1906.

Este acordo foi bem sucedido quanto a seus propósitos: regular o excesso de oferta (pelo acúmulo de estoques) e evitar novas quedas de preços. Entretanto, provocou sucessivas superproduções, dado que o café se mantinha como a alternativa de investimento mais viável. A demanda mundial, inelástica especialmente quanto à renda, permaneceu mais ou menos estável nos paises importadores nas primeiras décadas deste século. $O$ crescimento econômico verificado nos países adiantados na década de 1920 não provocou, assim, alta de preços (FURTADO, 1986, pp.181,183). Mas como a rentabilidade do café mantinha-se atrativa, continuava a aumentar sua oferta e, cada vez mais, tornava-se difícil retirar do mercado o volume excedente. 
Novos investidores continuaram a afluir à atividade cafeeira, e 1927 é conhecido como o ano que apresentou a maior área plantada. Em 1933, depois de concluída a fase e evolução biológica dos novos cafezais, a produção foi recorde. Pior momento para este excesso de produção não poderia haver: é o ano do ponto mais baixo na depressão que se havia iniciado em 1929 no capitalismo mundial. Como foi dito, a demanda por café é inelástica, e realmente pouco se alterou a quantidade consumida nos países centrais durante a depressão. Da mesma forma, os preços pagos pelo consumidor norte-americano não caíram tanto quanto os preços pagos ao produtor de café brasileiro (FURTADO, 1986, p.187). Esta situação surpreende à primeira vista, mas é fruto das condições especiais criadas do lado da oferta, que se tornava cada vez mais débil frente aos intermediários do comércio mundial. Os estoques que se acumulavam ano a ano não tinham a minima chance de serem vendidos num largo horizonte de tempo.

A crise que atinge a atividade cafeeira na década de trinta coloca a oligarquia cafeeira diante de um dilema: era preciso fazer um corte do lado da oferta, para evitar maior depressão dos preços. De onde viriam os recursos, contudo, para financiar uma eventual "queima" do excedente? Ora, até aquele momento a política de defesa do café havia sido financiada por capital externo, o qual agora era escasso devido à crise iniciada em 1929.

A expansão do crédito tomaria o lugar do financiamento externo. $O$ mecanismo cambial, por outro lado, foi crucial nos anos que se seguiram à crise de 1929 para evitar maiores perdas.

A forte queda nos preços do café e a rápida fuga de divisas do país levaram à desvalorização cambial (desvalorização da moeda brasileira). Este mecanismo funcionou como protetor da atividade cafeeira e, dada a importância da mesma no total da produção brasileira, também como sustentador do nível de renda, impedindo que a depressão externa tomasse conta da economia brasileira. Como assim? 
Ao ser desvalorizada a moeda brasileira, os dólares recebidos pelos exportadores geravam maior renda em réis. Assim, entre 1929 e 1931, caiu em $60 \%$ o preço internacional do café. Por outro lado, a desvalorização cambial chegou a $40 \%$ no mesmo período (FURTADO, 1986, p. 187), trazendo um grande alívio ao setor cafeeiro e permitindo manter o nível de atividade dentro do país. A experiência dos demais países capitalistas, que amargaram vários anos na depressão, não se repetiu, portanto, no Brasil. $O$ ano de maior baixa nas atividades brasileiras foi 1932, e já no ano seguinte voltou a crescer a renda nacional. Nos EUA, somente em 1934 começaram a se manifestar os primeiros sinais de recuperação.

Permanecia, contudo, o mesmo problema que acompanhava a lógica dos programas de valorização do café: a produção, se bem que não no mesmo ritmo da década de 1920, continuaria a se expandir, tornando insuficientes tais programas para conter o substancial aumento da oferta. Por outro lado, a desvalorização cambial não cobria todo o prejuízo causado pela queda do preço internacional do café. Algum desestímulo a novas inversões, portanto, já começava a se manifestar. Dessa forma, continuou o movimento de queda do preço ao longo dos anos 30 , o que gerava novas desvalorizações cambiais. Este mecanismo tinha um limite, o de que sucessivas diminuições de preço desencorajariam de tal forma os produtores que a oferta finalmente ajustar-seia à demanda.

O ajuste se deu de forma gradual, sendo importante enxergar os outros desdobramentos importantes decorrentes da perda de poder de compra da moeda brasileira. A valorização do dólar encareceu as importações, diminuindo seu coeficiente ${ }^{2}$ e levando ao equilíbrio num nivel mais baixo de consumo importado. Aos poucos, a demanda antes satisfeita pela produção externa passou a pressionar a produção interna.

2 Parte do consumo nacional que é preenchida com importações. 
Como foi dito, os investimentos industriais haviam sido esparsos e com reduzida integração na primeira fase. A partir de 1930 tem início o desenvolvimento do mercado interno no Brasil. É verdade que este foi gestado no período anterior, sob o impulso da economia cafeeira, mas é apenas com a crise do setor que começa a se manifestar o potencial do mercado interno brasileiro.

O encarecimento das importações foi decisivo para o impulso à produção interna. Num primeiro momento, as indústrias já instaladas passaram a aumentar a utilização da capacidade (a têxtil, mais uma vez, é o maior exemplo). Pela primeira vez, após várias décadas, apresentou-se uma alternativa de investimento ao café. Capitais novos e aqueles transferidos da atividade cafeeira encontraram na indústria resposta para suas aplicações. É verdade que os equipamentos para produção de mercadorias eram quase todos importados à época, e que portanto também tiveram seus preços elevados pela desvalorização cambial.

O crescimento do setor de bens de produção ocorreu assim mesmo, em parte devido à importação de equipamentos de segunda mão, comprados de paises que estavam em recessão, a preços muito inferiores aos dos equipamentos novos. Também há indícios de que a fabricação nacional de bens de produção começou a ganhar importância, num período de grandes dificuldades, revelando o impulso experimentado com a "descoberta" do mercado interno brasileiro.

O Estado Novo desempenhou um papel de extrema relevância ao intensificar os investimentos públicos, sobretudo em novas construções, e assim, a atividade industrial começou a diversificar-se. Boa parte do aumento de renda foi canalizado para novos investimentos, e a nação não dependia da importação de produtos agrícolas, outra pré-condição para que fosse possivel alcançar um maior grau de complexidade industrial. 
Esta é a chamada fase de "substituição de importações", nome que se consagrou devido tanto à pronunciada queda na capacidade de importação quanto ao aprofundamento do grau de nacionalização da produção e dos equipamentos industriais. Vimos que a fase anterior também teve um caráter substitutivo de importações, contudo a aceleração das exportações cafeeiras não exigia um esforço maior de implantação de um setor industrial mais integrado, dado que as carências porventura existentes podiam ser supridas com importações.

A evolução dos dados revela o extraordinário avanço alcançado no que tange ao desenvolvimento. Conforme a Tabela 12, nota-se que já em 1959 o país é auto-suficiente na produção de bens de consumo não-duráveis. É claro que ainda ocorre alguma importação, mas esta não é de forma alguma significativa. Quanto aos bens de consumo duráveis, a queda é notória: de 60\% em 1949 para 6\% em 1959 e auto-suficiência em 1964. Bens intermediários e de capital mostram evolução semelhante, caindo o nível de importações entre 49 e 64 para menos da metade. Fica claro, com estes dados, que o país alcançara alto grau de integração industrial.

\section{Tabela 12}

Participação das Importações no Total da Oferta do País

\begin{tabular}{lccc}
\hline Tipo de Bens & 1949 & 1959 & 1964 \\
\hline Bens Consumo Não Duráveis & $4 \%$ & -- & - \\
Bens Consumo Duráveis & $60 \%$ & $6 \%$ & - \\
Bens Intermediários & $25 \%$ & $12 \%$ & $10 \%$ \\
Bens de Capital & $60 \%$ & $33 \%$ & $20 \%$ \\
\hline
\end{tabular}

Fonte: Furtado (1969, pp.28-29)

Este desdobramento deixou marcas profundas na vida nacional, alterando o modo de vida e a localização de um contingente enorme de 
pessoas. A urbanização ganhou força, a renda per capita subiu de patamar e o Brasil diferenciou-se de seus parceiros latino-americanos, especialmente dos vizinhos. O caráter da industrialização efetivada nesta fase é concentrador, dado que o que o mundo tem a oferecer neste momento é fruto da tecnologia da grande escala, cada vez mais "capital-intensiva", o que, conjugado com um grande mercado de mão-de-obra contribuiu para manter os salários em niveis próximos ao de subsistência, favorecendo a maior apropriação de renda por parte das empresas e dos poucos detentores do capital.

O impulso à industrialização, nesta segunda fase (1930-1964), foi dado pela redução na capacidade de importação. Pelo menos num primeiro momento, quando o país sofreu as consequências da Grande Depressão, a demanda por bens anteriormente importados foi transferida para a produção nacional. Após a Segunda Guerra, contudo, fica claro que o Governo é que liderou o processo de industrialização.

A última fase de industrialização, correspondendo a períodos de crescimento, na verdade subdivide-se em dois ciclos distintos: o que vai de 1965 a 1973 e outro, que começa em 1974 e vai até 1979.

Contudo, os dados censitários, que são a base para o estudo do comportamento da distribuição de renda, são disponíveis a partir de 1960, e depois de dez em dez anos. Assim, os períodos relevantes para a análise passam a ser as décadas de 60, 70 e 80.

\section{2- A década de 60: Consenso nos resultados e divergência nas interpretações}

Os dados censitários de 1960 ainda não revelam informações mais abrangentes, como no caso dos Censos de 1970 e, principalmente, de 1980. Exemplificando, nas publicações do Censo de 1960 não se encontra a distribuição familiar da renda. Dados referentes à renda familiar só foram publicados a partir do Censo de 1980 . 
Em 1960, há evidências de que ainda se manifestava no Brasil um alto grau de atraso econômico, tendo como explicação que somente a partir de 30 as transformações estruturais passaram a ocorrer, gradativamente aumentando sua intensidade, mas encontrando dificuldades para superar uma herança arcaica secular.

Dados complementares confirmam, contudo, que a pobreza, além de abrangente, era intensa, principalmente na agricultura (porcentagens entre parênteses referem-se às cidades): apenas $8,4 \%$ dos domicílios rurais dispunham de instalação elétrica $(72,4 \%), 12,1 \%$ possuiam rádio $(61,6 \%) \mathrm{e}$ $1,3 \%$ geladeira $(23,3 \%)$; apenas $3,4 \%$ contavam com água corrente $(47,8 \%)$ e só $3 \%$ se ligavam à rede de esgotos ou possuíam fossa séptica $(47,2 \%)$ (SINGER, 1986, pp.26 e 28).

Teve-se, na década de 60 , três fases quanto ao desempenho macroeconômico brasileiro. Os anos iniciais, 60 e 61, foram de continuação do crescimento acelerado impulsionado pelo governo Juscelino Kubitschek. Entre 1962 e 1967 sofreu o país intensa crise político-econômica, quando a taxa de crescimento claramente perdeu vigor. Os anos finais, 1968 e 1969, são o começo do chamado milagre, o qual avançou nos anos iniciais da década de 70 .

Veja-se como se comportou a distribuição de renda no periodo, analisando o gráfico 7 e a tabela 13. A renda é a renda média de cada estrato. 


\section{Gráfico 7 - TAXA ANUAL DE CRESCIMENTO DA RENDA: 1960/70 (PEA com renda positiva)}

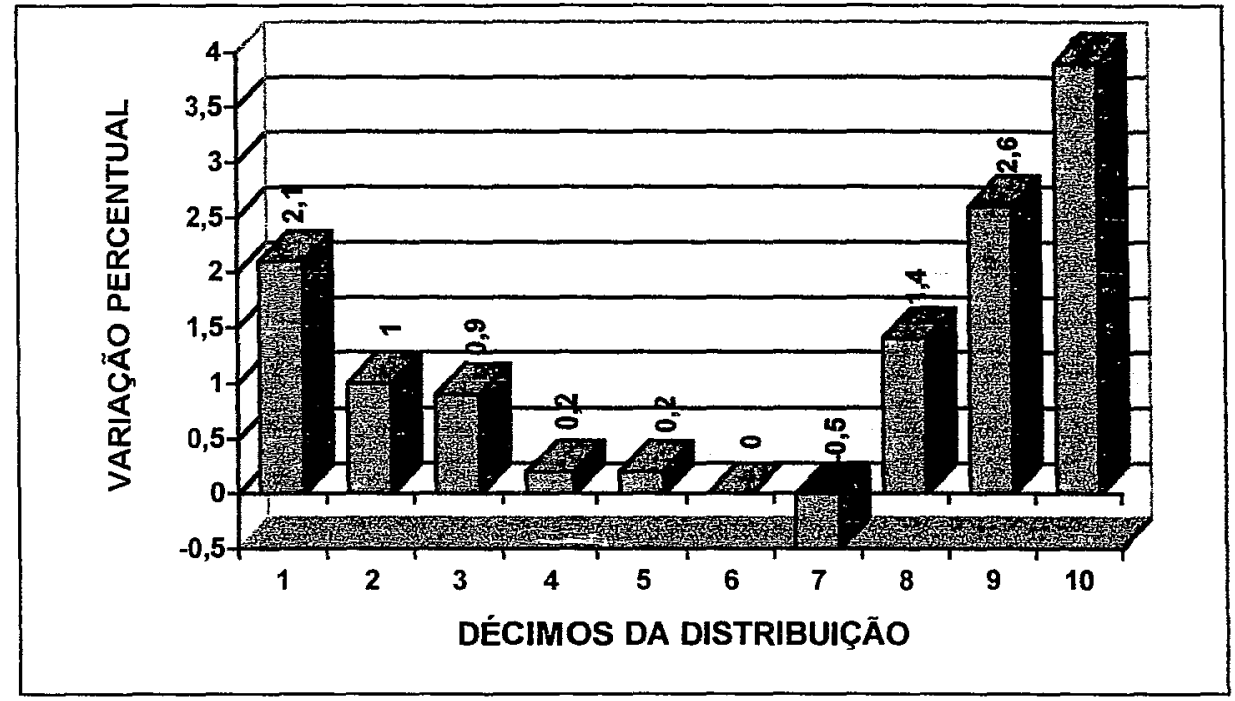

Fonte: BARROS \& MENDONÇA (1993, p.21)

Tabela 13

Distribuição do Rendimento e Variação na Renda Média da População Economicamente Ativa com Rendimento

\begin{tabular}{|c|c|c|c|c|c|}
\hline \multirow{3}{*}{ Estratos $^{1}$} & \multicolumn{2}{|c|}{1960} & \multicolumn{2}{|c|}{1970} & \multirow{3}{*}{$\begin{array}{c}\text { Mudança } \\
\% \text { na Ren- } \\
\text { da Média } \\
1970 / 60\end{array}$} \\
\hline & \multicolumn{2}{|c|}{$\%$ do Rendimento } & \multicolumn{2}{|c|}{ \% do Rendimento } & \\
\hline & No Estrato & Acumulado & No Estrato & Acumulado & \\
\hline $10^{\circ}$ & 1,2 & 1,2 & 1,2 & 1,2 & 23,7 \\
\hline $2 .^{\circ}$ & 2,3 & 3,5 & 2,0 & 3,2 & 10,2 \\
\hline $3 .^{\circ}$ & 3,4 & 6,9 & 3,0 & 6,2 & 9,4 \\
\hline $4^{\circ}$ & 4,6 & 11,5 & 3,8 & 10,0 & 2,2 \\
\hline $5 .^{\circ}$ & 6,2 & 17,7 & 5,0 & 15,0 & 1,8 \\
\hline $6 .^{\circ}$ & 7,7 & 25,4 & 6,2 & 21,2 & 0,5 \\
\hline $7 .^{\circ}$ & 9,4 & 34,8 & 7,2 & 28,4 & $-4,4$ \\
\hline $8 .^{\circ}$ & 10,9 & 45,7 & 9,9 & 38,3 & 14,4 \\
\hline $9 .^{\circ}$ & 14,6 & 60,3 & 15,2 & 53,5 & 28,7 \\
\hline $100^{\circ}$ & 39,7 & 100,0 & 46,5 & 100,0 & 46,2 \\
\hline Total & 100,0 & - & 100,0 & - & 24,8 \\
\hline $5+$ & 27,7 & - & 34,9 & - & nd \\
\hline $1+$ & 12,1 & - & 14,6 & - & nd \\
\hline
\end{tabular}

Fonte: BARROS \& MENDONÇA (1993, p.37, Apêndice - Tabela 8c)

Dados para 5+ e 1+ em BONELLI e RAMOS (1993, tabela 1, p.78)

${ }^{1}$ Décimos da população ordenada do mais pobre ao mais rico, $5 \%$ mais ricos $(5+)$ e $1 \%+\operatorname{ricos}(1+)$ 
Tanto no gráfico como na tabela é possível verificar com clareza a ocorrência de aumento da desigualdade na distribuição dos rendimentos. Conforme HOFFMANN (1995, p.278), o índice de Gini calculado, conhecido por suas propriedades de medição da concentração ou desigualdade da renda, é de 0,504 para 1960 e 0,561 para 1970, revelando um incremento da ordem de $11,3 \%$. É interessante notar que, além deste, todos os trabalhos que trataram do tema desde o início da década de setenta chegaram ao mesmo resultado: aumento no grau de concentração da renda, juntamente com o observado crescimento do produto no período. O aumento da renda média, conforme a Tabela 15 , foi de $24,8 \%$, ao passo que o crescimento do PIB per capita na década foi de $36 \%$. Esta diferença entre os índices pode se dever ao uso de um deflator inapropriado ou mesmo a problemas de comparabilidade dos dados censitários. Antes de se discutir as correntes que pretenderam explicar o fenômeno ocorrido, será buscada uma breve revisão do contexto políticoeconômico-social nos anos sessenta.

Comentou-se que no começo do período ocorreu continuação do crescimento, acelerado em meados da década de 50 , sob o impulso desenvolvimentista do Plano de Metas, do presidente Juscelino Kubitschek. Foi uma época em que os sindicatos passaram por um fortalecimento de sua capacidade reivindicatória, com mobilização do operariado, especialmente das categorias bem organizadas. Estas conseguiram defender o valor real de seus rendimentos, logrando mesmo uma redução no intervalo de reajuste, que passou a semestral em 1963 para todos os assalariados. Antes, em 1962, foi conquistado o direito ao $13 .^{\circ}$ salário. Em se tratando do governo federal, é um periodo de extrema instabilidade, com a renúncia de Jânio Quadros, a realização do plebiscito e a posse de João Goulart.

Começou a ganhar força nos meios militares a idéia de intervenção armada, com a finalidade de estabelecer a "ordem e o progresso" no país. Em março de 1964 ocorreu efetivamente o golpe que viria marcar profundamente 
os rumos da nação. Como se sabe, uma das principais características do regime implantado foi o uso da repressão em todos os setores da sociedade que representassem oposição ou potencial ameaça aos ideais de estabelecimento de um governo militar forte. Desarticulou-se o movimento operário, substituindo as diretorias anteriormente eleitas por interventores, ao mesmo tempo que parlamentares comprometidos com as reivindicações populares foram cassados. Na área rural, dura repressão atingiu os movimentos camponeses, levando à morte lideranças notórias (SINGER, 1986, p.30). Aos poucos, foi-se tendo o país sob controle, o qual era exercido desde os meios de comunicação, passando pela reestruturação do currículo escolar, até chegar ao exercício da força, levando ao desaparecimento de líderes dos meios acadêmicos e culturais.

Após este primeiro esforço do novo regime, foram anunciadas as reformas que viriam a ser implantadas através do Plano de Ação Econômica do Governo (PAEG). Estas, inclusive, serviram de pressuposto ideológico para as ações repressivas efetivadas. À frente do PAEG estava a dupla Roberto Campos/Otávio Bulhões, os quais elaboraram um plano de muito boa qualidade técnica, talvez o melhor de todos os planejamentos militares. Interessa-nos aqui a centralização da política salarial, efetivada a partir de 1965 , e a explicitação da preferência pela retomada do desenvolvimento acelerado.

Os reajustamentos salariais, que anteriormente ao golpe eram realizados através de acordos entre sindicatos patronais e de empregados, passaram a ser centralizados. A cada mês, o Governo Federal passou a baixar portaria fixando o índice de reajuste para as categorias cujos acordos expiravam no referido mês. Voltou a ser obrigatório o reajuste anual, proibindose intervalos menores que este. A fórmula do reajuste, que perdurou até 1979 , tinha por base o salário médio real dos 12 meses anteriores, ao qual se aplicava um índice correspondente à inflação futura esperada. Como é de 
amplo conhecimento, a inflação real superou persistentemente a esperada ao longo dos anos, contribuindo para um gradual arrocho salarial.

No campo da retomada do desenvolvimento, muitas reformas importantes foram realizadas. Revigorou-se a fonte de financiamento dos investimentos governamentais, através tanto da reforma tributária como do estabelecimento da verdade tarifária. A primeira atuou em duas frentes: incremento nos percentuais de aplicação, principalmente sobre o consumo, e maior poder de aplicação, com reforço da fiscalização. A segunda trouxe substanciais reajustes de preços públicos, que estavam defasados. Embora se buscasse redução dos níveis inflacionários, estas medidas contribuíram, num primeiro momento, para alimentar os indices de preços.

A política financeira do governo Castelo Branco ainda preconizava, entre outras, a reforma bancária, com criação do Conselho Monetário Nacional (C.M.N.) e do Banco Central. O Sistema Nacional de Crédito Rural derivou dessas reformas. A idealização e criação do mercado de capitais, bem como a elaboração do Estatuto da Terra também são destaques do programa econômico-social.

Com estas medidas, buscava-se ter um maior controle da emissão monetária, bem como disciplinar a irradiação do crédito pelo sistema financeiro nacional. Mais tarde, comprovou-se a importância desta reforma, quando nos anos do "milagre" o sistema de financiamento não se apresentou como entrave ao ritmo crescente das atividades.

É verdade que em fins dos anos 60 a economia mundial experimentou um último boom sincronizado, o qual perdurou até os anos iniciais da década seguinte, e o Brasil pôde contar com financiamento externo, o qual multiplicou a oferta de crédito na retomada do crescimento. Sem um sistema bancário ágil e sob controle essa maior oferta de recursos dificilmente chegaria às mãos dos investidores. A atuação do C.M.N. e do Banco Central também serviu à efetivação dos mecanismos clássicos de política monetária: mercado aberto, 
taxa de redesconto, depósitos compulsórios, monitoramento da taxa de juros etc.

Como política industrial, foram dados incentivos ao fortalecimento do setor de bens de consumo duráveis, que teve no ramo automobilístico seu maior expoente. Eletrodomésticos os mais variados também tiveram expansão notável. Embora ex-post muitas críticas tenham sido formuladas a esta política industrial, especialmente pelo seu curto ciclo de expansão, é inegável a contribuição que teve na expansão do produto e da renda nacionais e no aprimoramento da industrialização.

Ao fim dos anos 60 , era generalizada a euforia, especialmente nos meios governamentais, a tal ponto que não se imaginava estar ocorrendo simultaneamente um aumento substancial no grau de desigualdade. Quando os dados do Censo de 1970 foram divulgados, tardiamente se deu conta o governo de que a concentração de renda havia se tornado ainda maior. Assim, quando se chegou a um consenso acerca da verdade dos dados da Fundação IBGE, não restou outra alternativa ao Ministro da Fazenda senão afirmar ironicamente: "é melhor esperar o bolo crescer para depois dividi-lo" .

As diversas interpretações acerca do fenômeno do substancial aumento no grau de concentração da renda podem ser resumidas em duas grandes correntes: 1) a que dava destaque aos efeitos da política salarial, à inflação corretiva (decorrente dos reajustes dos preços públicos), à política econômica não neutra, aos subsídios a investimentos privados, à proliferação e inchamento dos salários gerenciais (pelo atrelamento destes aos niveis de lucro das empresas), à estrutura imperfeita dos mercados de trabalho e ao grau de competição; portanto, ressaltava a identificação de características próprias à economia brasileira; e 2) aquela que enfatizava mudanças clássicas na distribuição de renda, associadas com desenvolvimento acelerado, colocando o papel da educação como primordial na explicação das distâncias salariais entre trabalhadores diferentemente qualificados (naturalmente, o nivel 
educacional é tomado como proxi do grau de qualificação da mão-de-obra). (BONELLI e SEDLACEK, 1989, p.10). Merece destaque a obra de LANGONI (1973) dentro desta segunda linha de interpretação.

No atual estágio da evolução do pensamento econômico relativamente ao tema da distribuição de renda no Brasil nas últimas décadas, deve-se reconhecer que ambas as correntes são complementares como explicação do fenômeno ocorrido entre 1960 e 1970. Assim, uma análise que pretenda discutir o tema de forma enriquecedora, deve considerar a importância dos fatores presentes nas duas vertentes e, se possível, acrescentar algum fato novo.

Diversos estudos nos últimos anos têm comprovado o poder explicativo da educação na geração de desigualdades salariais.

O Brasil experimentou, a partir de 68 , altas taxas de crescimento do produto e, como contrapartida, aumentou significativamente a demanda por mão-de-obra. Uma vez que a pronunciada expansão e diversificação da produção industrial, bem como das atividades de comércio e serviços a ela ligadas, passou a requerer quantidades cada vez maiores de empregados qualificados, cuja oferta era inelástica a curto prazo, ocorreu natural incentivo a maiores remunerações para os trabalhadores que se ajustassem aos novos requisitos da indústria, em termos de qualificação profissional.

Esta corrente explicativa identificava como passageira a limitação quantitativa da oferta de mão-de-obra qualificada, a qual ajustar-se-ia a médio prazo à demanda. Assim, com o tempo, ocorreria tendência à redução da desigualdade. Outra ênfase era colocada na comparação com processos ocorridos nos países desenvolvidos, os quais experimentaram aumento no grau de concentração da renda nos anos de aceleração do crescimento econômico.

Quanto aos efeitos da educação sobre a desigualdade, serão analisados dados da década seguinte, à frente, a fim de possibilitar uma análise mais fundamentada a respeito desta relação. A transferência da população de 
atividades rurais para atividades industriais nas cidades, com consequente aumento da produtividade, a qual foi apropriada pelos empresários, devido principalmente à política salarial do período, a participação crescente de mulheres na força de trabalho etc. são fatores que contribuíram para o aumento da desigualdade. Como vimos, houve, a partir de meados da década de 60, intervenção na determinação dos níveis salariais e, concomitantemente, dura repressão aos movimentos reivindicatórios do operariado.

\section{3 - Anos 70: Crescimento com desigualdade}

Dados relacionados ao nível de vida revelam que, em 1970, no campo, (dados para as cidades entre parêntesis) $6,2 \%$ dos domicilios tinham água corrente $(52,6 \%) ; 2,0 \%$ possuiam esgoto ou fossa séptica $(44,2 \%) ; 8,4 \%$ contavam com instalação elétrica $(75,5 \%)$ e 3,2\% possuíam geladeira $(42,5 \%)$. Em relação aos dados apresentados no item anterior, nota-se que apenas tiveram crescimento substancial a posse de geladeira nas cidades. Os demais indicadores apresentam pequeno incremento, e no caso de esgoto ou fossa séptica há redução do percentual tanto nas cidades como no campo. Este foi um dos resultados do crescimento econômico experimentado nos anos sessenta.

De 1970 a 1980, especialmente até 1973, conheceu o Brasil as mais altas taxas de crescimento do produto. Entre 1970 e 1976, a renda real média da população cresceu 47,1\% (BONELLI \& SEDLACEK, 1989, p.20). No período todo, a variação da renda média foi de $96,5 \%$, conforme pode ser visto na Tabela 14 , ao passo que o crescimento do PIB per capita foi de $81 \%$, ou $6,1 \%$ ao ano. Vejamos como se comportou o grau de concentração ou desigualdade da renda. 


\section{Gráfico 8 - TAXA ANUAL DE CRESCIMENTO DA RENDA: 1970/80} (PEA com renda positiva)

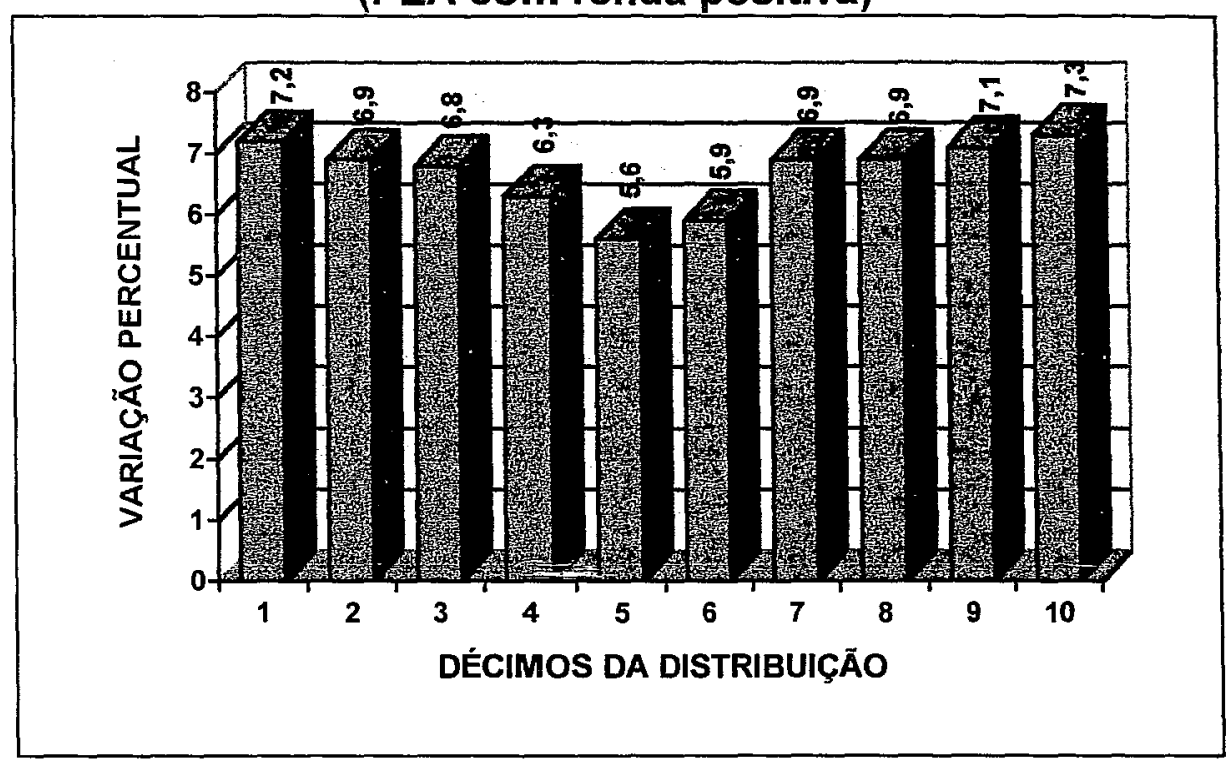

Fonte: BARROS \& MENDONÇA (1993, p.21)

Em comparação com a década anterior, o crescimento da renda nos anos 70 é muito maior e mais bem distribuído. Tanto o Gráfico 8 como a Tabela 14 ilustram este fato. Quatro estratos mantiveram sua participação relativa, quatro apresentaram piora relativa e os dois superiores foram, novamente, os únicos a aumentar sua participação na renda total. A última coluna da tabela, contudo, mostra que a diferença nos incrementos de renda média foi pequena entre os estratos, sobretudo dos inferiores em relação aos superiores. $O$ índice de Gini calculado em HOFFMANN (1995, p.278) é de 0,561 em 1970 e de 0,592 em 1980, revelando incremento menor, da ordem de $5,5 \%$, relativamente à variação da década anterior. 
Tabela 14

Distribuição do Rendimento e Variação na Renda Média da População Economicamente Ativa c/ Rendimento

\begin{tabular}{|c|c|c|c|c|c|}
\hline \multirow{3}{*}{ Estratos $^{1}$} & \multicolumn{2}{|c|}{1970} & \multicolumn{2}{|c|}{1980} & \multirow{3}{*}{$\begin{array}{c}\text { Mudança } \\
\% \text { na Ren- } \\
\text { da Média } \\
1980 / 70\end{array}$} \\
\hline & \multicolumn{2}{|c|}{$\%$ do Rendimento } & \multicolumn{2}{|c|}{ \% do Rendimento } & \\
\hline & No Estrato & Acumul. & No Estrato & Acumulado & \\
\hline $10^{\circ}$ & 1,2 & 1,2 & 1,2 & 1,2 & 99,8 \\
\hline $2 .^{\circ}$ & 2,0 & 3,2 & 2,0 & 3,2 & 94,5 \\
\hline $3 .^{\circ}$ & 3,0 & 6,2 & 2,9 & 6,1 & 93,2 \\
\hline $4 .^{\circ}$ & 3,8 & 10,0 & 3,6 & 9,7 & 84,1 \\
\hline $5 .^{\circ}$ & 5,0 & 15,0 & 4,4 & 14,1 & 72,6 \\
\hline $6 .^{\circ}$ & 6,2 & 21,2 & 5,6 & 19,7 & 77,7 \\
\hline $7 .^{\circ}$ & 7,2 & 28,4 & 7,2 & 26,9 & 95,4 \\
\hline $8 .^{\circ}$ & 9,9 & 38,3 & 9,9 & 36,8 & 95,1 \\
\hline $9 .^{\circ}$ & 15,2 & 53,5 & 15,3 & 52,1 & 99,2 \\
\hline $10 .^{\circ}$ & 46,5 & 100,0 & 47,9 & 100,0 & 102,5 \\
\hline Total & 100,0 & - & 100,0 & - & 96,5 \\
\hline $5+$ & 34,9 & - & 34,9 & - & nd \\
\hline $1+$ & 14,6 & - & 18,2 & - & nd \\
\hline
\end{tabular}

Fonte: BARROS \& MENDONÇA (1993, Apêndice - Tabela 8c, p.37)

Dados para 5+e 1+ em BONELLI e RAMOS (1993, tabela 1, p.78)

${ }^{1}$ Décimos da população ordenada do mais pobre ao mais rico, $5 \%$ mais ricos $(5+)$ e $1 \%+\operatorname{ricos}(1+)$

Como ocorrera nos dez anos anteriores, a década de 70 mostra evolução diferenciada, seja em termos do ritmo de crescimento, seja em termos da evolução da desigualdade na distribuição de renda.

De 1970 a 1976, altas taxas de crescimento do produto e da renda se fazem presentes, influenciadas pelo milagre. Foram, sem dúvida, os melhores anos em termos de desempenho econômico, anos de otimismo, em que o governo militar soube tirar proveito para aumentar seu prestígio junto à população. Em relação à desigualdade, os anos de 1970 e 1971 dão continuidade ao avanço da concentração. Conforme SINGER (1986, p.70), a parcela de renda dos $10 \%$ mais ricos subiu de $46,7 \%$ para $52,6 \%$, enquanto a 
dos $60 \%$ mais pobres diminuiu de $20,9 \%$ para $16,8 \%$ (dados para 1970 compatíveis com os da tabela 16). Entre 1972 e 1976, contudo, ocorre, pela primeira vez, desde 1960, alguma tendência à desconcentração da renda: cai a participação dos $10 \%$ mais ricos para $50,1 \%$ e aumenta a dos $60 \%$ mais pobres para $18,3 \%$.

Qual seria a explicação para tal mudança de rumo? Sabemos que a política salarial continuou a mesma até 1979 , e que no movimento sindical o quadro se mantinha também inalterado. O maior "aliado" da mão-de-obra assalariada no período foi o ritmo do crescimento econômico, o qual parece ter levado a produção a níveis próximos do pleno emprego.

Sabe-se que a partir de fins dos anos 60 houve no Brasil uma multiplicação da oferta de mão-de-obra qualificada, espelhada pelo aumento de profissionais com curso superior, que serviu muito bem à demanda ampliada por ocupações técnicas e administrativas. Entre 1970 e 1976, a taxa de participação das pessoas com dez ou mais anos na PEA sobe de $44,9 \%$ para $49,9 \%$. Particularmente intenso foi o incremento no número de pessoas com ocupações administrativas $(73,6 \%)$, científicas e técnicas $(73,3 \%)$ e industriais, incluindo a construção civil $(66,0 \%)$.

Quanto aos profissionais menos qualificados, é bastante provável que tenha passado a ocorrer disputa pelos mesmos entre as diversas empresas. Houve aumento na participação de pessoas que trabalhavam 50 e mais horas por semana, de $24,8 \%$ em 1970 para $29,1 \%$ em 1976 , fato que revela crescimento no número de horas trabalhadas para acompanhar o ritmo de crescimento (SINGER, 1986, p.72).

Em resumo, os dados para os anos iniciais da década de 70 parecem confirmar um aspecto da explicação baseada no conteúdo educacional da mãode-obra. A maior oferta de trabalhadores qualificados contribuiu em boa medida para suprir a demanda por esse tipo de mão-de-obra, sem provocar um aumento demasiado no nivel de suas remunerações. Por outro lado, se houve 
incrementos salariais para ocupações de maior conteúdo educacional, houve também para os trabalhadores menos qualificados, os quais inclusive auferiram maiores rendimentos através do aumento no número de horas trabalhadas.

De 1976 a 1980 perde vigor esta última explicação, juntamente com a perda de dinamismo da economia. É verdade que as taxas de crescimento do produto ainda se mantiveram altas, acima da taxa de crescimento da população, levando a um aumento da renda per capita da ordem de 17,4\%, conforme RAMOS (1990, p.6). Este autor busca mostrar que, no período 1976 1985, nos anos em que há crescimento econômico, a economia brasileira apresenta um padrão de diminuição da desigualdade, ao passo que na recessão ocorre aumento na concentração da renda. $A$ racionalidade por trás deste desempenho está em que, havendo crescimento, aumenta a demanda por trabalhadores não qualificados, sendo estes os primeiros a perderem seus empregos na recessão, dado que é mais difícil repor a mão-de-obra com maior conteúdo educacional numa eventual retomada do nível de atividade.

Esta explicação pode ser plausível para o período sob análise naquele trabalho, mas, como visto, nos anos do milagre econômico, quando o aumento na renda per capita foi muito maior, ocorreu aumento da desigualdade, pelo menos até 1972. Isto mostra que, na ausência de possibilidades reivindicatórias por parte dos trabalhadores, não há mecanismo natural que reparta os frutos do aumento da produtividade.

Propõe-se aqui enfatizar uma explicação diferente para a diminuição da desigualdade no final dos anos 70. A partir da metade dessa década aumentaram as dificuldades no controle da economia por parte do governo militar. A decisão de optar pela continuação do crescimento num contexto que apontava claramente para um ajuste frente aos choques do petróleo revela que as bases de sustentação do regime dependiam em larga medida de altas taxas de desenvolvimento. A verdade é que, mesmo com a implantação de alguns "mega-projetos" do II P.N.D., desacelerou-se o crescimento, ao mesmo tempo 
que os militares passaram a considerar sua saída do poder, de maneira "lenta e segura".

Do ponto-de-vista da distribuição de renda, interessa ressaltar que o enfraquecimento do regime permitiu que ocorresse uma tolerância antes nunca observada para com movimentos reivindicatórios. A partir de 1978, começaram a estourar greves por todo o país, levando o governo a enviar ao Congresso, em 1979, novo projeto de lei salarial. Com base no INPC, os assalariados com renda de até três salários mínimos receberiam $110 \%$ do índice. Os que ganhavam até dez salários, $100 \%$ do INPC sobre a faixa de três a dez (e 110\% sobre a faixa até três mínimos). Acima de dez, o indice a ser aplicado seria de $80 \%$ do INPC. Portanto, influenciado pelo fortalecimento do movimento sindical, decidiu o governo impor política salarial destinada a recompor parte do poder de compra das camadas menos favorecidas. Esta recomposição darse-ia, contudo, à custa não do lucro, mas dos salários mais altos.

Assim, não se pode negar a contribuição que tiveram as greves e a política salarial na redução da desigualdade nos anos finais da década de setenta. Entre 1976 e 1980, a renda dos $30 \%$ mais pobres cresceu 6,8\%, a dos $40 \%$ médios aumentou $8,1 \%$, ao passo que a dos $30 \%$ mais ricos sofreu queda de $1,4 \%$ (entre os $10 \%$ superiores, a queda foi ainda maior, da ordem de 4,0\%), conforme BONELLI \& SEDLACEK (1989, p.20).

No âmbito internacional, é comum atribuir-se importância ao movimento operário como tendo papel decisivo na distribuição mais equitativa dos ganhos de produtividade, após um período inicial de concentração da renda, correspondente às fases iniciais de crescimento acelerado. A literatura econômica que se tem dedicado ao estudo do comportamento da distribuição pessoal de renda no Brasil nas últimas décadas tem dado pouca importância a este aspecto, salvo poucas exceções (com destaque para Paul Singer).

O papel da educação como determinante do nível de qualificação da mão-de-obra e, por conseguinte, dos níveis de renda é importante na 
explicação do comportamento da mesma. Outro fator que influencia a distribuição dos rendimentos são os movimentos de expansão e contração no nivel de emprego, aumentando a desigualdade em tempos de contração (os trabalhadores menos qualificados, ou os da base da pirâmide salarial são os primeiros a perder seus empregos).

Este trabalho mostra, contudo, que a repressão ao movimento sindical, acompanhado do arrocho salarial, foi importante para o aumento no grau de desigualdade verificado entre 1964 e 1972. Na segunda metade da década de setenta, quando se permitiu maior liberdade de ação ao movimento operário, ocorreu redução da desigualdade. Evidencia-se, portanto, a importância da evolução dos movimentos reivindicatórios na explicação do comportamento da distribuição da renda.

\section{4 - A Década de 80: Aumento da desigualdade como uma das faces da crise}

Há maior riqueza de dados nos anos oitenta, seja no Censo, no qual é divulgada a renda familiar, seja nas PNADs, que cobrem toda a década sem interrupção da publicação em qualquer ano.

A tabela 15 reproduz parte da Tabela 3 do trabalho de HOFFMANN (1995, p.284), para analisar a evolução da pobreza ao longo da década. 
Tabela 15

Evolução da pobreza absoluta entre famílias classificadas de acordo com seu rendimento familiar, no Brasil, de 1980 a 1995

\begin{tabular}{ccccccc}
\hline Ano & \multicolumn{2}{c}{$\mathrm{z}=1$ sal.mín.de agosto/1980 } & \multicolumn{2}{c}{$\mathrm{z}=2$ sal.mín.de agosto/ 1980} \\
\hline & $\mathrm{H}$ & $\mathrm{P}$ & \multicolumn{2}{c}{$\mathrm{r}(\%)$} & $\mathrm{H}$ & $\mathrm{P}$ \\
\cline { 2 - 7 } 1980 & 0,219 & 0,128 & 1,9 & 0,444 & 0,281 & 8,8 \\
1981 & 0,213 & 0,135 & 2,2 & 0,436 & 0,284 & 9,6 \\
1982 & 0,217 & 0,136 & 2,1 & 0,445 & 0,287 & 9,4 \\
1983 & 0,263 & 0,168 & 3,2 & 0,494 & 0,335 & 13,5 \\
1984 & 0,259 & 0,163 & 3,1 & 0,493 & 0,331 & 13,4 \\
1985 & 0,226 & 0,140 & 2,3 & 0,449 & 0,295 & 10,2 \\
1986 & 0,152 & 0,098 & 1,2 & 0,336 & 0,213 & 5,2 \\
1987 & 0,222 & 0,142 & 2,2 & 0,427 & 0,286 & 9,3 \\
1988 & 0,233 & 0,148 & 2,3 & 0,446 & 0,299 & 9,9 \\
1989 & 0,214 & 0,138 & 1,9 & 0,414 & 0,278 & 7,9 \\
1990 & 0,265 & 0,173 & 3,0 & 0,473 & 0,328 & 11,8 \\
1992 & 0,251 & 0,151 & 2,9 & 0,491 & 0,320 & 13,2 \\
1993 & 0,243 & 0,146 & 2,7 & 0,492 & 0,318 & 12,2 \\
1995 & 0,175 & 0,109 & 1,4 & 0,407 & 0,254 & 6,3 \\
\hline
\end{tabular}

Fontes: HOFFMANN (1995, p.284), para o período 1980/1990 e cálculos baseados em

IBGE (1996b), para os anos 1992 e 1993 e IBGE (1996d) para o ano de 1995.

z: linha de pobreza interpolada. O valor real da linha de pobreza é mantido constante utilizando como deflator o INPC restrito com periodo de referência ajustado para o mês civil nos anos anteriores a 1986.

H: Proporção de famílias pobres

$P$ : Índice de pobreza de Sen. Este é definido como: $P=H\left[1+(1-1) G^{*}\right]$, onde $H$ é a proporção de pobres na população, I é a razão de insuficiência de renda e $\mathrm{G}^{*}$ é 0 indice de Gini entre os pobres.

$r$ : insuficiência de renda como porcentagem da renda total.

Dados a partir de 1981 excluindo a área rural da Região Norte.

Chama atenção a linha referente ao ano de 1986, que é o ano do Plano Cruzado. Todos os índices relacionados à pobreza são os menores da década, 
o que revela os efeitos benéficos do referido plano na melhoria do bem-estar. Após 1986, contudo, a aceleração da inflação parece anular estes efeitos, de forma que rapidamente se retorna aos niveis anteriores, e em 1990 tanto a porcentagem de pobres como o índice de pobreza de Sen são os maiores de todo o período $1980-1990$, quando se considera " $z$ " igual a um salário mínimo de agosto de 1980 . Os anos iniciais da presente década revelam que poucas foram as alterações nesses indicadores, mas de qualquer forma sua evolução foi positiva - no sentido de diminuição da pobreza. Em relação ao início do período, contudo, tanto $\mathrm{H}$ quanto $\mathrm{P}$ permanecem elevados.

Com "z" igual a dois salários mínimos de agosto de 1980 as variações nos índices seguem a mesma tendência. Apenas diferenças mínimas de variação ano a ano acontecem relativamente ao desempenho dos índices da linha de pobreza igual a 1 salário mínimo. Entretanto, a proporção de famílias pobres $(H)$ continua a crescer em 1992 e 1993, e o Índice de Pobreza de Sen, embora diminua com relação a 1990, permanece elevado relativamente à maioria dos anos da década de 80 .

Quando se considera as pessoas classificadas de acordo com seu rendimento per capita, é menos desfavorável a evolução da pobreza absoluta na década de 80 (HOFFMANN, 1995, p 283). Isto se deve a que o tamanho das famílias vem diminuindo, sendo que nas famílias com renda mais baixa a diminuição é mais intensa. Assim, estabelecendo como linha de pobreza o valor real igual a $1 / 4$ do salário mínimo de outubro de 1981, para pessoas ordenadas conforme seu rendimento per capita, a proporção de pobres passa de 0,225 em 1981 para 0,224 em 1988 e 0,228 em 1990 .

Apresenta-se no Gráfico 9 e Tabela 16 o comportamento do rendimento médio dos décimos da distribuição da renda na PEA, na década de oitenta. 
Gráfico 9 - TAXA ANUAL DE CRESCIMENTO DA RENDA: 1980/90 (PEA com renda positiva)

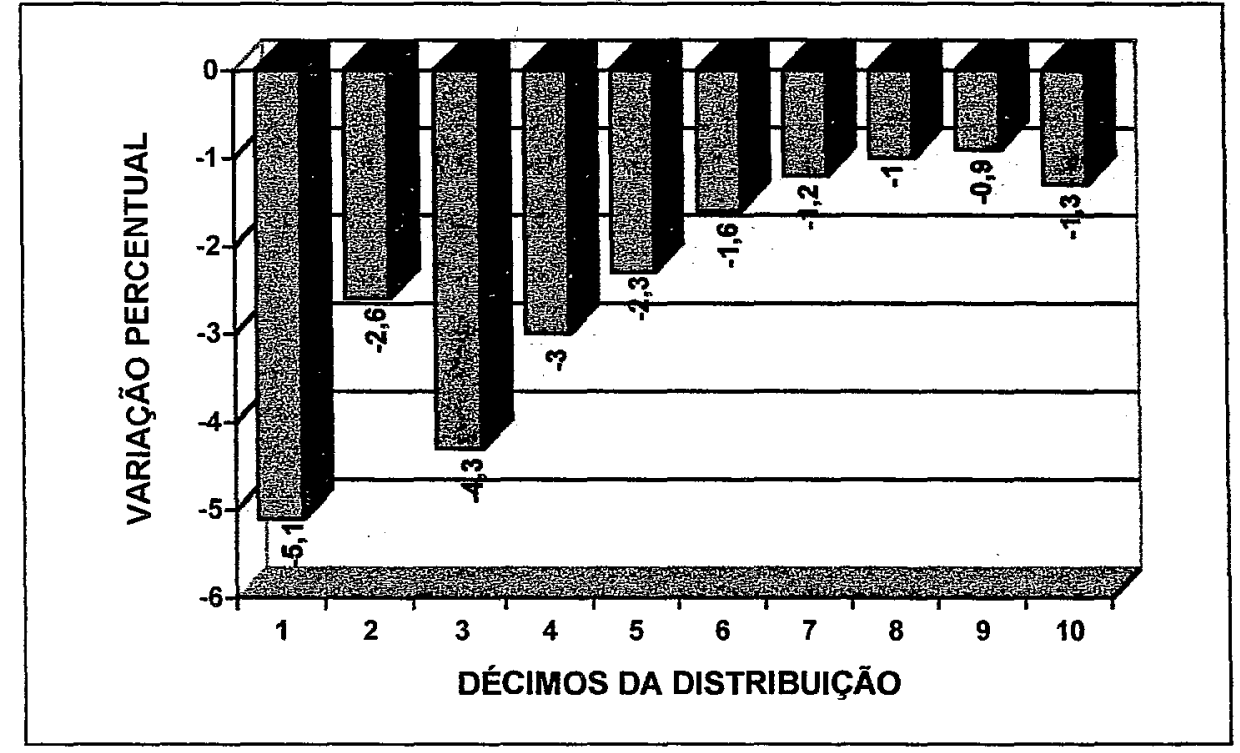

Fonte: BARROS \& MENDONÇA (1993, p.22)

Tabela 16

Distribuição do Rendimento e Variação na Renda Média da População Economicamente Ativa c/ Rendimento

\begin{tabular}{|c|c|c|c|c|c|}
\hline \multirow{3}{*}{ Estratos $^{1}$} & \multicolumn{2}{|c|}{1980} & \multicolumn{2}{|c|}{1990} & \multirow{3}{*}{$\begin{array}{c}\text { Mudança } \\
\% \text { na Ren- } \\
\text { da Média } \\
1990 / 80\end{array}$} \\
\hline & \multicolumn{2}{|c|}{ \% do Rendimento } & \multicolumn{2}{|c|}{ \% do Rendimento } & \\
\hline & No Estrato & Acumulado & No Estrato & Acumulado & \\
\hline $1 .^{\circ}$ & 1,2 & 1,2 & 0,8 & 0,8 & -41 \\
\hline $2 .^{\circ}$ & 2,0 & 3,2 & 1,8 & 2,6 & -24 \\
\hline $3 .^{\circ}$ & 2,9 & 6,1 & 2,2 & 4,8 & -35 \\
\hline $4 .^{\circ}$ & 3,6 & 9,7 & 3,0 & 7,8 & -27 \\
\hline $5 .^{\circ}$ & 4,4 & 14,1 & 4,0 & 11,8 & -21 \\
\hline $6 .^{\circ}$ & 5,6 & 19,7 & 5,5 & 17,3 & -15 \\
\hline $7 .^{\circ}$ & 7,2 & 26,9 & 7,3 & 24,6 & -12 \\
\hline $8 .^{\circ}$ & 9,9 & 36,8 & 10,3 & 34,9 & -10 \\
\hline $9 .{ }^{\circ}$ & 15,3 & 52,1 & 16,4 & 51,3 & -9 \\
\hline $10 .^{\circ}$ & 47,9 & 100,0 & 48,7 & 100,0 & -12 \\
\hline Total & 100,0 & - & 100,0 & - & $-13,7$ \\
\hline $5+$ & 34,9 & - & 35,8 & - & nd \\
\hline $1+$ & 18,2 & - & 14,6 & - & nd \\
\hline
\end{tabular}

Fonte: BARROS \& MENDONÇA (1993, Apêndice - Tabela 8c, p.37)

Dados para 5+ e 1+ em BONELLI e RAMOS (1993, tabela 1, p.78)

${ }^{1}$ Décimos da população ordenada do mais pobre ao mais rico, $5 \%$ mais ricos $(5+)$ e $1 \%+\operatorname{ricos}(1+)$ 
Foi medíocre o desempenho da economia nos anos 80 . Todos os estratos de renda perdem no período, com a agravante de que a penalidade é maior à medida que a renda diminui. A variação da renda real média no período foi de $-13,7 \%$, conforme a Tabela 16. O PIB per capita de 1990 foi $4,3 \%$ menor que o de 1980 . É verdade que o ano de 1990 , tomado para comparação, apresenta renda significativamente mais baixa, acentuando o desempenho negativo.

Sabe-se que o esforço do governo militar em prolongar o crescimento econômico, a despeito da crise do petróleo, agravou as condições para o ajuste na década de 80 . Entre 1976 e 1979, devido à relativa abundância de recursos internacionais (expansão do euromercado), aumentou sobremaneira o endividamento brasileiro. Neste último ano, para agravar uma situação que já se apresentava preocupante, subiram os juros internacionais, sobrecarregando o serviço da dívida. Os credores externos continuaram a fornecer empréstimos ao Brasil em 1980, mas passaram a exigir do governo brasileiro um reequilibrio das contas externas, mediante políticas recessivas, que começaram a ser praticadas em 1981, desencadeando a crise dos anos 80 .

Dois anos após, contudo, agravou-se a problemática, quando o México se declarou inadimplente e foram cortados todos os empréstimos novos aos países endividados. Neste contexto, ocorreu a união dos paises credores, os quais impuseram, na ausência de uma resistência que poderia ter-se efetivado em uma também união dos países devedores, políticas "saneadoras" do receituário do Fundo Monetário Internacional. Estas tiveram por efeito a exacerbação da inflação e o aprofundamento da crise.

Em 1983, o governo passou a baixar uma série de decretos-leis, com o objetivo de fazer com que os reajustes salariais ficassem abaixo da variação do INPC. A partir de fevereiro, trabalhadores que recebiam até três mínimos deixaram de ter reposição acima da variação do INPC; a partir de agosto, todos os assalariados passaram a repor suas perdas em apenas $80 \%$ do INPC; 
em novembro, voltaram os trabalhadores com renda de até três salários mínimos a ter reposição integral. Os com renda entre sete e quinze mínimos tiveram reposição fixada em $60 \%$ da variação do INPC e trabalhadores na faixa acima de quinze salários mínimos passaram a receber apenas $50 \%$ do INPC (SINGER, 1986, p.51).

Esta instabilidade demonstrada na fixação da política salarial revela que o governo teve dificuldades em implantar o pacote recessivo preconizado pelo FMI. Mesmo assim, deixaram de operar as forças institucionais que estavam promovendo uma redistribuição da renda em favor das camadas mais baixas, ainda que a mesma não tivesse sido substancial. Em 1984 e 1985 ocorreu uma ligeira recuperação econômica, a qual contribuiu para evitar uma retomada mais significativa no crescimento da desigualdade, através daquele efeito apresentado à p.70 (RAMOS, 1990).

O ano de 1986 foi atípico, na medida em que trouxe beneficios gerais para a economia. O mais famoso choque heterodoxo dos anos 80 intentou quebrar o ímpeto inflacionário, decretando congelamento geral de preços e salários. Ganhos reais para os assalariados foram concedidos logo no início do plano, especialmente para os da base da pirâmide salarial, provocando súbita mas limitada redução da desigualdade.

Pressões de preços, refletidas no desaparecimento da oferta de muitas mercadorias, indicavam a necessidade de um ajuste, já por volta de julho daquele ano, com a finalidade de rever aqueles que se encontravam demasiadamente defasados. Por motivos estritamente políticos, arrastou-se o congelamento até as eleições de novembro, tendo por resultado que, ao se afrouxar o congelamento, retornou com maior ímpeto o processo inflacionário. Claro está que o Plano Cruzado foi deveras limitado na eliminação das verdadeiras causas da inflação.

De 1987 a 1990, a exemplo do contexto que havia se iniciado em 1986, a economia brasileira caminhou entre surtos de crescimento moderado e 
choques de estabilização. A tônica da trajetória neste período é de aceleração da inflação após cada novo choque. O sistema de indexação da economia, útil na recomposição (nem sempre total) do poder de compra, atuava também como realimentador da inflação. Praticamente todos os formadores de preços, incluindo desde pequenos comerciantes até grandes conglomerados industriais, acostumaram-se a remarcar seus preços tendo como referência a inflação do mês anterior, à qual se somava uma porcentagem, já prevendo aumento do índice de preços, incrementando seus ganhos potenciais.

A inflação persistente desregulou de tal forma o sistema de preços que a concorrência ficou nebulosa nos mercados onde deveria atuar.

O resultado, conforme mostrado pela Tabela 15 , foi um aumento no nível de pobreza no país e certamente, da desigualdade. Os índices de Gini, considerando a PEA com rendimento positivo, para estes anos, são os seguintes: 0,595 em 1987, 0,617 em 1988, 0,636 em 1989 e 0,607 em 1990 (HOFFMANN, 1995, p.286). Apenas em 1989 ocorre redução dos índices de pobreza, o que pode ser explicado por se tratar de mais um ano eleitoral, com gastos atípicos sendo realizados, para influenciar o voto dos eleitores, em geral, e o das camadas mais pobres da população, em particular. A PNAD capta justamente a conjuntura do mês de referência da pesquisa, que neste ano foi setembro, bastante próximo, portanto, das eleições.

E qual a explicação para o crescimento da desigualdade após 1986? É verdade que a indexação da economia provia reposição da inflação passada para os trabalhadores. Quanto maior a aceleração do nivel de preços, contudo, menor ficava, em termos reais, o salário ao longo dos meses, ou mesmo em períodos menores, como dentro de um mês. As aplicações financeiras ganhavam cada vez mais importância como mecanismo de defesa contra a inflação. O acesso às aplicações, contudo, sempre foi mais fácil para os detentores de rendas mais altas, que normalmente realizam operações mais volumosas. 
Assim, as camadas de renda média mais baixa perderam participação nos rendimentos relativamente às camadas de renda mais elevada, fator que, no entanto, não é captado pelos dados. Quando são levantadas informações acerca do rendimento, só excepcionalmente algum informante inclui no total de seus rendimentos ganhos que teve no mercado financeiro.

Dessa forma, a aceleração da inflação tornou-se cada vez mais inimiga dos assalariados, especialmente dos situados nas esferas inferiores da dispersão salarial. Quanto mais se aproxima de níveis associados à hiperinflação, contudo, as perdas são muito mais generalizadas.

Vários trabalhos recentes têm comprovado a existência de uma correlação positiva e altamente significativa entre nível de inflação e evolução da desigualdade. HOFFMANN (1995, pp.290-293) estima várias equações de regressão, associando variações no índice de Gini (ou de Theil) a variações: no índice de inflação (INPC, no caso), na renda média e na evolução temporal, para o período 1979-1990, ressaltando o fato de se tratar de uma série pequena, em virtude de os dados anuais da PNAD se relacionarem a um mês de referência específico. Mesmo assim, os resultados apresentam claramente as tendências. A influência do aumento da inflação sobre as medidas de desigualdade é, num sentido, real, à medida que, ao longo do tempo, os salários perdem mais em relação a juros e lucros, devido às defasagens nos reajustes. Por outro lado, há um efeito associado à presença de "ruído" nos dados: com inflação elevada, cresce substancialmente a imprecisão da informação sobre rendimento.

No periodo de maior aceleração da inflação, após 1986, é que a influência da mesma sobre a desigualdade se torna evidente, conforme ressaltam BONELLI e RAMOS (1993). No estudo de HOFFMANN (1995, p.291) também é constatada uma relação entre rendimento médio e índice de desigualdade na forma de " $U$ " invertido, conforme a hipótese de Kuznets. Mais uma vez, deve-se ressaltar que a série é pequena e, portanto, não é 
apropriada para testar tal hipótese, referida ao longo prazo, fator comprovado pelo teste $F$ para a hipótese de nulidade dos coeficientes de $m$ e $m^{2}$ (com $m=$ rendimento médio), com dois e sete graus de liberdade, o qual não é significativo ao nível de $10 \%$. Os dados utilizados para o rendimento médio situam-se, contudo, em torno da parte ascendente da curva (com exceção dos valores para 1986 e 1989), o que comprova uma associação positiva entre crescimento da renda e aumento da desigualdade, exceto em 1986 e 1989.

Finalmente, o trabalho de CARDOSO (1993), utilizando dados mensais da Pesquisa Mensal de Emprego (PME) da Fundação IBGE, para seis regiōes metropolitanas (S. Paulo, Rio de Janeiro, B. Horizonte, Porto Alegre, Salvador e Recife) durante os anos 80 , mostra como variações significativas no grau de desigualdade no curto prazo podem ser explicadas pelo comportamento macroeconômico.

Realizando regressões para os indices de Gini, de Theil e de Theil para desigualdade interna de grupos com o mesmo tempo de estudo, contra índices do nivel de desemprego, inflação, salário mínimo real e taxa real de troca (ou de câmbio), chega a resultados cujos coeficientes explicativos são todos positivos e altamente significativos, respondendo por $3 / 4$ da variação na desigualdade total, no caso dos índices de Gini e Theil, e por mais de $50 \%$ da variação na desigualdade para o Theil entre grupos com mesmo tempo de estudo.

\section{5 - O Período 1960/1990: houve perdedores?}

Algumas análises do processo de industrialização brasileiro nas últimas décadas ressaltam a não neutralidade da política econômica, chegando a afirmar que o desenvolvimento econômico do periodo gerou um contingente não desprezivel de excluídos dos benefícios trazidos pelos anos de 
prosperidade. Até que ponto podemos considerar o processo de industrialização brasileiro como tendo sido excludente?

Após acompanhar a trajetória da desigualdade ao longo das últimas três décadas, examina-se neste item em que medida o crescimento econômico entre 1960 e 1990, em que pese a estagnação do crescimento e queda na renda média de todos os estratos nos anos 80 , beneficiou ou deixou de beneficiar as diversas classes de renda.

\section{Gráfico 10 - TAXA ANUAL DE GRESCIMENTO DA RENDA: 1960/90} (PEA com renda positiva)

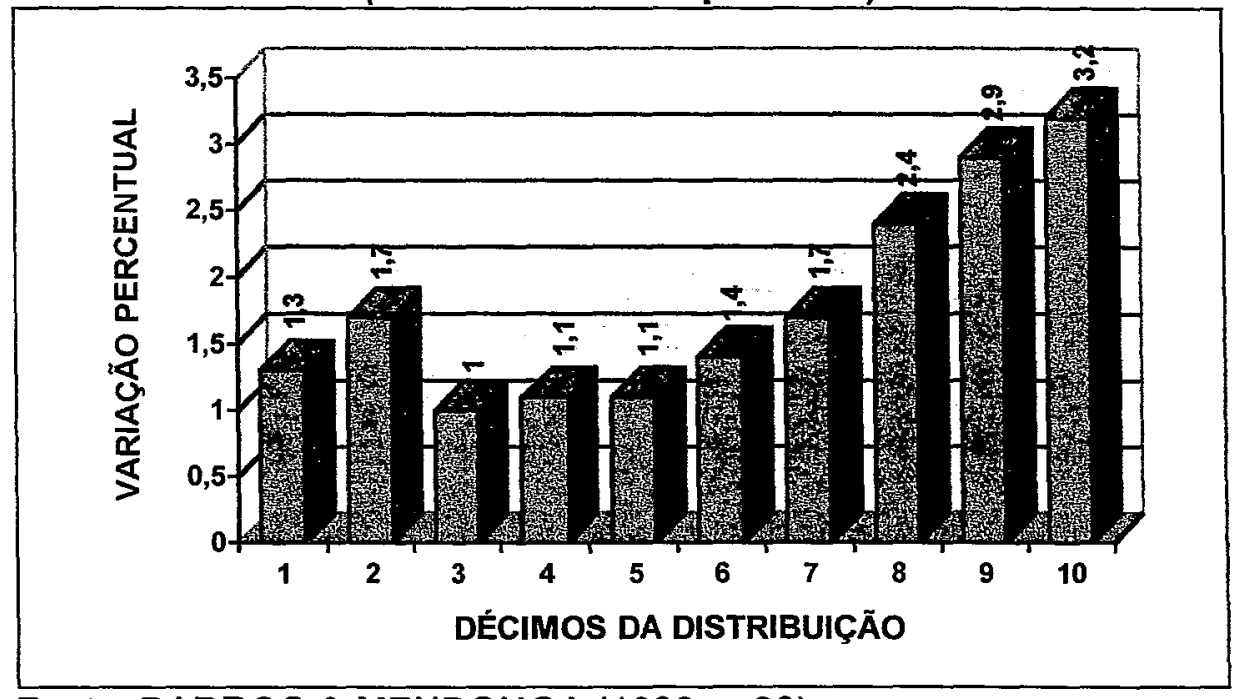

Fonte: BARROS \& MENDONÇA (1993, p.20) 
Tabela 17

Distribuição do Rendimento e Variação na Renda Média da População Economicamente Ativa c/ Rendimento

\begin{tabular}{|c|c|c|c|c|c|}
\hline \multirow{3}{*}{ Estratos $^{1}$} & \multicolumn{2}{|c|}{1960} & \multicolumn{2}{|c|}{1990} & \multirow{3}{*}{$\begin{array}{c}\text { Mudança } \\
\% \text { na Ren- } \\
\text { da Média } \\
1990 / 60\end{array}$} \\
\hline & \multicolumn{2}{|c|}{$\%$ do Rendimento } & \multicolumn{2}{|c|}{ \% do Rendimento } & \\
\hline & No Estrato & Acumulado & No Estrato & Acumulado & \\
\hline $1 .^{\circ}$ & 1,2 & 1,2 & 0,8 & 0,8 & 46,9 \\
\hline $2 .^{\circ}$ & 2,3 & 3,5 & 1,8 & 2,6 & 64,0 \\
\hline $3 .^{\circ}$ & 3,4 & 6,9 & 2,2 & 4,8 & 36,4 \\
\hline $4 .^{\circ}$ & 4,6 & 11,5 & 3,0 & 7,8 & 38,2 \\
\hline $5 . .^{\circ}$ & 6,2 & 17,7 & 4,0 & 11,8 & 39,7 \\
\hline $6 .^{\circ}$ & 7,7 & 25,4 & 5,5 & 17,3 & 51,2 \\
\hline $7 .^{\circ}$ & 9,4 & 34,8 & 7,3 & 24,6 & 65,2 \\
\hline $8 .^{\circ}$ & 10,9 & 45,7 & 10,3 & 34,9 & 101,3 \\
\hline $9 .^{\circ}$ & 14,6 & 60,3 & 16,4 & 51,3 & 134,3 \\
\hline $100^{\circ}$ & 39,7 & 100,0 & 48,7 & 100,0 & 159,8 \\
\hline Total & 100,0 & - & 100,0 & - & 116,8 \\
\hline $5+$ & 27,7 & - & 35,8 & - & nd \\
\hline $1+$ & 12,1 & - & 14,6 & - & nd \\
\hline
\end{tabular}

Fonte: BARROS et alii (1993, Apêndice - Tabela 8c, p.37)

Dados para 5+ e 1+ em BONELLI e RAMOS (1993, tabela 1, p.78)

${ }^{1}$ Décimos da população ordenada do mais pobre ao mais rico, $5 \%$ mais ricos $(5+)$ e $1 \%+\operatorname{ricos}(1+)$

À primeira vista, conforme indicam os dados, não houve perdedores no período.

Claramente, contudo, os maiores beneficiados pelo crescimento econômico entre 1960 e 1990 foram os estratos mais altos da distribuição.

Dado que houve aumento da renda média em todos os estratos no periodo 60/90, mas inegavelmente aumento da desigualdade, seria lícito afirmar que a população brasileira encontra-se em 1990 em situação melhor que a de 1960 ? Em outras palavras, aumentou o bem-estar da população?

O bem-estar associa-se a estes dois movimentos: variações na renda média e no grau de desigualdade. Vimos que ocorreu, no entanto, entre 1960 e 
1990, aumento na renda média e aumento na desigualdade, variações estas que afetam o bem-estar em sentidos contrários. Como avaliar o resultado líquido destes dois movimentos?

Desenvolvimentos relativamente recentes (SHORROCKS, 1983) tornam possível a estimação da variação no bem-estar associada a movimentos na renda média e no grau de desigualdade, mesmo que estes afetem o bem-estar de maneira antagônica.

Torna-se necessário introduzir, então, os conceitos de dominância de primeira e de segunda ordem. Afirma-se que dada distribuição $A$ domina determinada distribuição $B$ pelo critério de primeira ordem se, e somente se, todos os estratos de $A$ apresentam maior nivel de rendimento relativamente a $B$.

Considerando a variação anual média da renda, percebe-se que a distribuição da década de 1970 (gráfico 8, p.66) domina a da década de 60 (gráfico 7, p.58) pelo conceito de dominância de primeira ordem, visto que, nos anos 60 , o sétimo estrato teve piorada sua condição de renda. Além do mais, na década de 1970 todos os estratos melhoraram substancialmente sua condição relativamente à década anterior. Os anos 80 mostram claramente mudança de tendência, com perdas para todos os estratos.

Tomando 1990 em relação a 1960 observa-se dominância de primeira ordem. Uma vez que essa condição é satisfeita, pode-se afirmar inequivocamente que houve melhora no bem-estar da população.

O critério de segunda ordem tem como vantagem a incorporação do comportamento da desigualdade, utilizando um procedimento relativamente simples: o de multiplicar a curva de Lorenz, a qual capta completamente a desigualdade na distribuição, pela renda média.

A curva de Lorenz é construída a partir de informações relativas à apropriação da renda por parte de cada estrato da população, em ordem crescente. Na abscissa, tem-se a proporção acumulada da população e na 
ordenada respectiva, a proporção acumulada de renda. No gráfico, uma curva de Lorenz mais alta significa menor grau de desigualdade. Multiplicando-a pela renda média, tem-se a curva de Lorenz generalizada.

Exemplificando, quando comparamos duas situações, em anos distintos, sendo uma curva de Lorenz mais alta que outra, o efeito da multiplicação pela renda média pode mudar a posição relativa das mesmas, caso a renda média seja muito maior naquele ano relacionado à curva de Lorenz mais baixa.

Mas e no caso de haver aumento da desigualdade? Muito bem, um aumento inequívoco na desigualdade faz com que a curva de Lorenz passe a ser mais baixa. Mas a multiplicação pela renda média pode levar a que um crescimento destacado desta suplante o efeito negativo de um aumento da desigualdade. O contrário não é verdade: piora na renda média, associada a uma redução na desigualdade conduz, assim mesmo, a uma curva de Lorenz generalizada inferior, pelo menos em seu lado extremo direito, uma vez que o valor neste ponto é igual à renda média. Dessa forma, não se teria uma curva de Lorenz generalizada mais alta em todos os pontos, condição necessária para afirmar uma melhora no bem-estar pelo critério de segunda ordem.

Pode haver, entretanto, situações em que duas curvas de Lorenz generalizadas se cruzam, não sendo possível, então, identificar qual das duas distribuições é melhor pelo critério de segunda ordem.

O gráfico 11 apenas confirma a melhora no bem-estar entre 1960 e 1990. 
Gráfico 11

Curvas de Lorenz Generalizadas

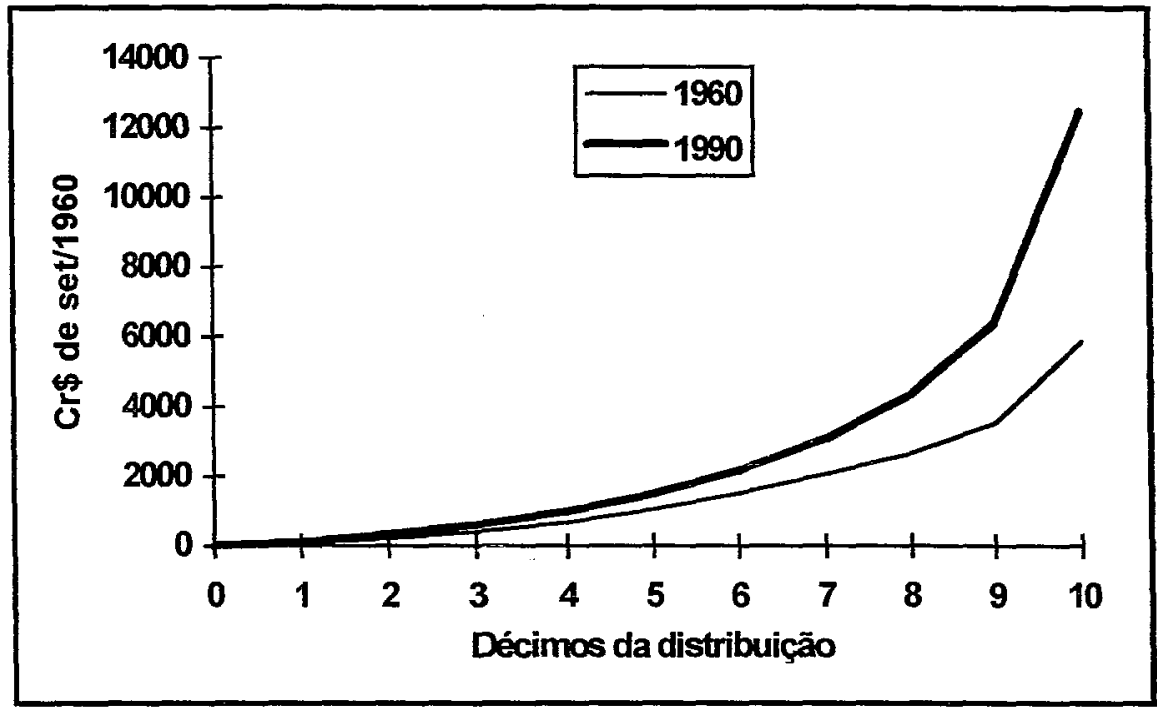

Fonte: BARROS \& MENDONÇA (1993, P.25)

Deflator:IGPC-MTb/INPC-R

Outra forma de acompanhar o desempenho da desigualdade refere-se à análise do comportamento da mobilidade social. A mobilidade é definida como a efetivação de alterações na posição social relativa dos indivíduos ao longo do tempo.

A Fundação IBGE passou a pesquisar informações sobre a evolução do status ocupacional apenas a partir de 1973 (e depois somente em 1982 e 1988), mas isso não quer dizer que o período de cobertura seja demasiadamente pequeno.

$\mathrm{Na}$ verdade, o questionário utilizado na pesquisa, com a amostra abrangendo pessoas de 10 anos ou mais em todas as regiões, perguntou sobre a ocupação atual do indivíduo em 1973, sua primeira ocupação e a ocupação de seu pai por ocasião do primeiro emprego do indivíduo. Assim, coletaram-se informações que cobrem a maior parte do presente século, levando em consideração, exemplificando, que indivíduos que tinham 60 anos em 1973 começaram a trabalhar cerca de 40 ou 45 anos antes. 
Tabela 18

Padrões de Mobilidade Social - PNADs 1973/1988 (\%)

\begin{tabular}{lcccccc}
\hline TIPO DE MOBILIDADE & \multicolumn{3}{c}{ INTERGERACIONAL } & \multicolumn{3}{c}{ INTRAGERACIONAL } \\
\cline { 2 - 7 } & 1973 & 1982 & 1988 & 1973 & 1982 & 1988 \\
\hline Ascendente & 47,1 & 39,9 & 37,4 & 54,2 & 26,1 & 27,3 \\
Imobilidade & 41,6 & 32,4 & 35,2 & 41,9 & 69,4 & 67,0 \\
Descendente & 11,3 & 27,6 & 27,3 & 3,9 & 4,5 & 5,7 \\
TOTAL & 100, & 100, & 100, & 100, & 100, & 100, \\
\hline
\end{tabular}

Fonte: PASTORE (1993, p.33)

Pode-se ver que, no geral, a dinâmica ocorrida até 1973 foi de criação de muitas oportunidades ocupacionais. O crescimento acelerado recrutou pessoas qualificadas e mesmo não-qualificadas para o exercício das novas atividades, de maior qualificação. Assim, muito do treinamento foi efetuado dentro da nova profissão, e certamente muita improvisação também foi necessária. Pensando em termos dos indivíduos móveis (excluindo a parcela de imobilidade), $80,6 \%$ e $93,4 \%$ tiveram mobilidade ascendente (respectivamente para mobilidades inter e intrageracional) e $19,4 \%$ e 6,6\% descendente.

Já em 1982 e 1988 percebe-se que tanto a mobilidade ascendente quanto a imobilidade decrescem, dando lugar ao substancial incremento da mobilidade descendente, quando se observa as colunas referentes ao movimento intergeracional.

Ao longo da carreira, as possibilidades de ascenção reduzem-se muito mais significativamente, mas com o resultado de que a imobilidade é que aumenta bastante sua participação. Ou seja, em que pese ser o periodo 1973/1988 pequeno em termos da identificação de tendências na mobilidade 
social, as quais se cristalizam ao longo de décadas, já se pode perceber que a estrutura social brasileira vem se tornando mais rígida.

Tabela 19

Distribuição da renda entre pessoas economicamente ativas com rendimento, no Brasil, e Índice de Gini nos anos de 1960, 1970 e 1980.

\begin{tabular}{lllll}
\hline \multicolumn{1}{c}{ ANO } & $50-$ & $10+$ & $\mathrm{I}(\%)$ & GINI \\
\hline Censos & & & & \\
1960 & 18,0 & 40,5 & 58 & 0,504 \\
1970 & 15,6 & 46,7 & 55 & 0,561 \\
1980 & 13,8 & 49,6 & 34 & 0,592 \\
\hline
\end{tabular}

Fonte: HOFFMANN (1995, p.278)

I= Proporção de pobres. Linha de pobreza interpolada igual ao salário mínimo de agosto de 1980

Tabela 20

Distribuição da renda entre famílias de acordo com o rendimento familiar, no Brasil, e Índice de Gini, de 1981 a 1995

\begin{tabular}{lllll}
\hline \multicolumn{1}{c}{ ANO } & $50-$ & $10+$ & $\mathrm{H}$ & GINI \\
\hline PNADs & & & & \\
1981 & 12,9 & 45,8 & 0,213 & 0,584 \\
1982 & 12,6 & 45,7 & 0,217 & 0,587 \\
1983 & 12,6 & 45,9 & 0,263 & 0,589 \\
1984 & 12,8 & 46,3 & 0,259 & 0,588 \\
1985 & 12,5 & 46,5 & 0,226 & 0,592 \\
1986 & 12,9 & 45,6 & 0,152 & 0,586 \\
1987 & 12,2 & 46,5 & 0,222 & 0,597 \\
1988 & 11,8 & 47,5 & 0,233 & 0,606 \\
1989 & 11,2 & 48,3 & 0,214 & 0,617 \\
1990 & 11,7 & 46,4 & 0,265 & 0,603 \\
1992 & 13,7 & 43,8 & 0,251 & 0,567 \\
1993 & 12,9 & 46,5 & 0,243 & 0,588 \\
1995 & 12,6 & 45,8 & 0,175 & 0,589 \\
\hline
\end{tabular}

Fonte: HOFFMANN (1995, pp.281 e 284) para o período 1981-90 e cálculos do mesmo autor baseados em IBGE (1996b) para os anos de 1992 e 1993 e IBGE (1996d) para 1995.

Notas: $(50-)=$ apropriação da renda pelos $50 \%$ mais pobres.

$(10+)=$ apropriação da renda pelos $10 \%$ mais ricos

$G=$ Indice de Gini

$H=$ Proporção de famílias pobres, com linha de pobreza interpolada com valor real de um salário mínimo de agosto de 1980.

Está excluída a área rural da Região Norte. 
$O$ índice de Gini passa de cerca de 0,5 em 1960 para perto de 0,6 em 1980. A partir daí, mantém certa estabilidade. Isto denuncia a persistência de um alto grau de desigualdade em nosso pais, no longo prazo. A apresentação dos dados revela que a pretendida transitoriedade da desigualdade defendida na maioria dos trabalhos da década de 70 não se confirmou.

Tomando por referência, contudo, o fato de que o desenvolvimento da industrialização - que começou a ganhar força na década de 40 e acelerou-se visivelmente no período $60 / 80$ - contou com uma base social muito precária e atrasada no início, o crescimento verificado nas últimas décadas contribuiu para superar as carências da estrutura social brasileira, mas aquém do que realmente poderia.

Até 1980 , ocorreu contínua redução na proporção de pobres, um dos benefícios causados pelo rápido crescimento econômico. HOFFMANN (1995, p278), no entanto, afirma que, caso não tivesse ocorrido aumento da desigualdade no período $60 / 80$, de forma que todos os estratos da distribuição mantivessem sua posição relativa, o efeito do aumento da renda média verificado teria reduzido a proporção de pessoas pobres de $58 \%$, em 1960 , para $26 \%$, em 1980 , e não para $34 \%$, como realmente ocorreu. Note-se que é substancial a diferença entre estes dois últimos índices. Foi perdida, com certeza, uma grande chance de reduzir ainda mais a pobreza no Brasil.

Utilizando dados do Banco Mundial, pode-se verificar que o Brasil tem indices de pobreza que o fazem participar de um grupo que, em sua maioria, é composto de países com menor grau de desenvolvimento econômico. 
Tabela 21

Alterações nos indicadores de pobreza em países selecionados

\begin{tabular}{|c|c|c|c|c|}
\hline \multirow[t]{2}{*}{ País e período } & \multicolumn{2}{|c|}{ Índice de Pobreza } & \multicolumn{2}{|c|}{$\begin{array}{c}\text { Número de pobres } \\
\text { (milhões) }\end{array}$} \\
\hline & $1^{\circ}$ ano & Último ano & $1^{\circ}$ ano & Último ano \\
\hline Brasil $(1960-87)^{a, b}$ & 50 & 24 & 36,1 & 33,2 \\
\hline Colômbia (1971-88) ${ }^{a}$ & 41 & 25 & 8,9 & 7,5 \\
\hline Costa Rica $(1971-86)^{a}$ & 45 & 24 & 0,8 & 0,6 \\
\hline Índia (1972-83) & 54 & 43 & 311,4 & 315,0 \\
\hline Indonésia (1970-87) & 58 & 17 & 67,9 & 30,0 \\
\hline Malásia $(1973-87)^{a}$ & 37 & 15 & 4,1 & 2,2 \\
\hline Paquistão (1962-84) & 54 & 23 & 26,5 & 18,7 \\
\hline Tailândia (1962-86) & 59 & 26 & 16,7 & 13,6 \\
\hline
\end{tabular}

Fonte: Banco Mundial (1990, pp.41 e 43)

Notas: As linhas de pobreza são específicas de cada país, mas foram utilizados, sempre que possivel, delimitadores comuns ou oficiais.

${ }^{a}=$ baseado em renda, e não em consumo; ${ }^{b}=$ refere-se a famílias, e não a indivíduos, exceto para o Brasil - 1987.

Embora não excludente, o modelo de desenvolvimento brasileiro entre 1960 e 1990 foi concentrador e limitado. A primeira idéia já se encontra discutida neste texto. Quanto à limitação do desenvolvimento econômico brasileiro, decorre do fato de que para chegar à condição de nação desenvolvida, também é necessário alcançar razoável grau de desenvolvimento social. Um país que mantém a quarta parte de sua população na pobreza ainda está distante da superação da condição de país em desenvolvimento ou de nação emergente. 


\section{4 - REDISTRIBUIÇÃO DA RENDA: UM DOS POSSÍVEIS CAMINHOS}

\section{1 - A questão teórica}

Fala-se muito na retornada do desenvolvimento no Brasil. Houve crescimento do produto em 1994 e 1995, mas aquém de taxas que seriam possiveis sem as restrições da política monetária contracionista executada. $O$ empenho maior do atual governo é no sentido de evitar a volta do processo inflacionário. Tendo em vista o potencial de crescimento da economia brasileira, torna-se urgente uma retomada do mesmo a maiores taxas. Respeitando os ideais estabilizadores, muitas propostas, que em última instância objetivam a retomada do crescimento econômico, têm surgido, estando por trás a idéia de que é possível realizar crescimento sem aumento no grau de desigualdade da renda. A análise do capitulo anterior revelou que 0 padrão dominante no Brasil desde 1960 foi o crescimento de ambas, renda e desigualdade.

Desta forma, fala-se em consolidação do processo de estabilização, realização das reformas tributária e fiscal, controle dos gastos governamentais, controle da política cambial, e por fim adoção de medidas de incentivo à produção e desenvolvimento tecnológico. Isto, sem falar nas medidas relacionadas à adequação do capital humano com vistas à retomada do crescimento. Num contexto como este, contudo, a redistribuição de renda tem um caráter subordinado, ou no máximo de "companheiro" da retomada do crescimento. 
O objetivo deste trabalho visa um caminho um pouco diferente, no sentido de verificar qual o comportamento da demanda agregada após uma redistribuição dos rendimentos em favor das camadas mais baixas da distribuição, podendo ser esta uma opção com o intento de retomar o desenvolvimento auto-sustentado.

\subsection{1 - A Refutação da "Lei de Say"}

A idéia de realizar uma redistribuição de renda em favor dos estratos mais pobres não é nova no pensamento econômico. Keynes, em sua Teoria Geral, originalmente da década de 30 , já formulara esta proposição, embora em termos um pouco diferentes ${ }^{3}$. A demanda efetiva, entretanto, já estivera sendo discutida por Marx e por autores marxistas que o sucederam, sob o tema da realização da produção.

Segundo a concepção de Marx, a existência do dinheiro abre a possibilidade de crises, em virtude de que a moeda não é apenas um meio de troca, mas também pode ser entesourada, na função conhecida como reserva de valor.

Uma vez entesourada a moeda, parte da produção deixa de ser vendida no mercado, deixa de ser realizada, resultando em desestímulo à produção. Esta é a gênese da maioria das crises do capitalismo - a insuficiência de demanda, especialmente de investimento.

Dentro deste contexto, a definição da economia como sendo o estudo da alocação de recursos escassos não faz muito sentido. O problema do capitalismo, na maioria das vezes, não é de escassez de oferta, e sim de ausência de demanda! As duas grandes depressões da economia mundial, no

\footnotetext{
3 “Ademais, a experiência ensina que, nas condições existentes, a poupança por meio de instituições e de fundos de amortização é mais adequada, e que as medidas destinadas a redistribuir a renda no sentido
} 
final do século passado e nos anos trinta deste século, resultaram em provas irrefutáveis desta verdade. A busca de novos mercados, ou a maior exploração de mercados com potencial de expansão, implícita no processo de globalização econômica, revela que ainda hoje persiste o problema da insuficiência de demanda.

Entretanto até a ocorrência da segunda grande crise, foi dominante a interpretação econômica segundo a qual a produção cria sua própria demanda. Esta proposição é conhecida como "Lei de Say", em referência ao economista francês que formulou o mecanismo. Ricardo, no entanto, foi quem mais claramente o descreveu. Dentro da linha marxista rejeitou-se desde o princípio esta teoria.

Os economistas neoclássicos assumiram a "Lei de Say" como um dogma, talvez pela influência de Ricardo, o qual incorporou o princípio à sua teoria. Uma série de conclusões, muitas das quais persistem até hoje, mesmo que apenas implicitamente, foram tiradas, entre as quais a doutrina do pleno emprego, a impossibilidade de crises (excetuando-se desajustes temporários e restritos a bens e serviços particulares) e outras mais. Nem todos os economistas de linhagem clássica, contudo, aceitaram a "Lei de Say". Entre estes, merecem destaque Thomas Robert Malthus e Simonde de Sismondi (MIGLIOLI, 1981, p.55).

É interessante notar que Malthus, embora com a presença de algumas imprecisões em sua teoria, antecipou em quase um século proposições presentes na teoria da demanda efetiva.

O polonês Michal Kalecki, contemporâneo de Keynes, formulou um corpo teórico original, buscando explicar a dinâmica capitalista sob a ótica da demanda efetiva. Kalecki tem o mérito de dar sequência à obra de Marx a partir do ponto que não foi por este suficientemente desenvolvido: os determinantes

de aumentar a propensão a consumir podem ser muito favoráveis ao crescimento do capital." (KEYNES, 1985, p. 253, grifos do autor deste trabalho) 
da demanda. Marx estudou exaustivamente as condições de oferta, mas do lado da demanda apenas discutiu algumas idéias.

No princípio da demanda efetiva, retoma importância o papel dos mercados na determinação do ritmo de acumulação. A produção gera um poder de compra potencial, mas que se realiza efetivamente apenas no ato de compra (ou de venda). A própria crise iniciada em 1929 colocava a descoberto o princípio: com um tremendo acúmulo de estoques, ficava difícil sustentar a afirmação de que a produção gera sua própria demanda. Em outras palavras, a demanda não era ilimitada, sendo antes determinada por outros fatores.

$\mathrm{Na}$ formulação da teoria, inverteu-se o sentido da determinação. A demanda é composta por gastos em consumo e investimento (adicionalmente, gastos do governo e transações externas). Quanto menor a renda, maior a propensão a consumir, dadas as necessidades individuais. Os gastos em investimento, de caráter autônomo, têm um papel fundamental.

Num contexto como o que presenciaram Keynes e Kalecki, a proposição foi no sentido da realização de gastos até mesmo improdutivos, visto que a demanda, uma vez realizada, exerce influência positiva no estado de expectativas. Havendo investimento no aumento da produção, mais trabalhadores passam a receber remuneração, a qual será gasta em bens de consumo, retornando à classe capitalista, acrescido de lucro, o capital empregado. Assim, o aumento dos gastos na economia como um todo gera um nível de atividades cada vez maior, levando à retomada do desenvolvimento econômico.

Após a II Guerra, desenvolveu-se com vigor a pesquisa no campo do crescimento econômico. As teorias do crescimento endógeno exploraram o exame da influência de fatores tais como a educação, infra-estrutura e gastos governamentais, entre outros, na determinação do desenvolvimento.

No fértil campo do crescimento econômico e distribuição de renda, sabese da influência das teorias de Kuznets ao longo de décadas. Nos últimos 
anos, entretanto, perdeu muita força a aceitação daquelas proposições, as quais postulam que há uma relação do tipo "em forma de $U$ invertido" entre o crescimento da renda média e o grau de desigualdade da distribuição dos rendimentos. Numa sociedade em desenvolvimento, a renda cresce a partir de níveis baixos. Num primeiro momento, deve aumentar a desigualdade da renda, e apenas a partir do ponto de máximo da relação é que se reverte esta tendência.

Estas conclusões repousam em dois fatos empíricos: 1) os países ricos, que já passaram pela fase de desenvolvimento acelerado, apresentam distribuição de renda mais equitativa relativamente aos países pobres ou em desenvolvimento; 2 ) o crescimento das sociedades em desenvolvimento após a II Guerra revela, com poucas exceções, uma piora nos já desfavoráveis índices de desigualdade nestas nações.

Ultimamente, entretanto, tem crescido a resistência em aceitar o postulado "crescimento já, redistribuição depois". A principal razão é a dúvida quanto às possibilidades da efetivação da redistribuição como mecanismo automático, após certo lapso de tempo. A esse respeito, o Brasil é um excelente exemplo para o mundo. Desde meados da década de 70 espera-se dividir os frutos do crescimento, o que ocorreu apenas quando houve pressão por parte dos trabalhadores, e tendo alcance muito pequeno, dadas as perdas a seguir verificadas, na década de 80 . Um segundo motivo remete à importante questão de quanto crescimento é sacrificado agora com o propósito de uma melhor distribuição depois.

A teoria que ressalta o papel da política na inter-relação com a economia foi outra área de pesquisa que evoluiu muito, especialmente em anos mais recentes.

O crescimento econômico despertou grande interesse nos estudiosos desde os primórdios da teoria econômica. No último século, verificaram-se processos de crescimento econômico em diferentes contextos políticos. 
Particularmente nos países menos desenvolvidos, aí incluída a América Latina, a ocorrência de crescimento econômico em regime ditatorial levou a se interpretar que somente com regime forte seria possivel sustentar algum crescimento. O estudo dos impactos da política sobre a economia tenta, entre outras coisas, analisar a validade de interpretações como esta.

\subsection{2 - Aspectos Políticos e sua Relação com o Crescimento e a Distribuiçãode Renda}

Um tema que ainda pode ser aprofundado em termos de pesquisa empírica (e mesmo teórica) nesta área diz respeito a regimes políticos e crescimento econômico (ALESINA \& PEROTTI, 1994). Com relação ao conhecimento já acumulado neste tema, faz-se necessário definir democracia.

Há, basicamente, duas interpretações: 1) democracia é o regime experimentado por uma nação que tenha eleições livres, regulares e com pluralidade partidária; 2) democracia também se relaciona ao quantum de liberdades econômicas e civis da população. Assim, o regime militar experimentado no Brasil não se enquadra na primeira definição. Na segunda, contudo, relativiza-se muito o papel da ditadura, dando abertura à interpretação do regime através dos direitos à disposição dos cidadãos.

Assim, o Brasil, bem como algumas nações do Sudeste Asiático (Hong Kong, República Coreana, Singapura e Taiwan), apesar de terem vivido ditaduras, podem ter permitido maior grau de liberdades econômicas (principalmente) e civis, e este fator deve ser levado em consideração.

A inter-relação entre regime político e crescimento pode ser compreendida através da demanda que eleitores exercem por políticas redistributivas. Num ambiente com eleições livres, o governo é levado a alguns impasses, a fim de atender essas reivindicações. Como a experiência mostra, o 
inchamento do Estado é, normalmente, o resultado de seu comprometimento com programas de benefícios ao setor privado da economia. A ampla geração de empregos é outra característica. Assim, no intuito de manter-se no poder, incorre o governo em políticas que comprometem a otimização de sua participação na economia.

Argumenta-se, contudo, que ditaduras também estão expostas a demandas semelhantes. Como visto, o regime militar no Brasil manteve-se no poder enquanto tinha respaldo de amplos setores da sociedade. Quando começou a enfraquecer sua base de sustentação, na metade da década de 70 , o contexto econômico era totalmente desfavorável, sugerindo uma recessão. $A$ fim de continuar no poder, o governo optou por um programa desenvolvimentista, o II PND. Esta não era, claramente, a melhor saída, visto que implicava aumentar o endividamento externo, ainda mais tendo em vista que todos os países com alto consumo de petróleo seguiram pelo caminho da desaceleração econômica. Do ponto de vista político, contudo, foi a única alternativa viável. Assim, a crise dos anos 80 foi reforçada pelos resultados (em termos de vulnerabilidade) decorrentes dos programas do II PND.

Análises quantitativas ligando regime político e crescimento econômico são bastante inconclusivas, sendo possível encontrar resultados em sentidos contrários. O maior motivo para isto repousa na heterogeneidade das ditaduras, havendo aquelas que contribuem para um crescimento acelerado e outras que $o$ inibem. Por outro lado, as democracias são muito mais homogêneas, normalmente contribuindo para um crescimento mais forte e duradouro.

A afirmação que pode ser feita com base nas pesquisas é de que democracia e liberdades civis, embora não resultem sempre em crescimento econômico, normalmente contribuem para a ocorrência do mesmo. 
Já no âmbito da instabilidade política e crescimento econômico, as preocupações iniciais dos pesquisadores são com a definição de instabilidade política e como tratar o problema de correlação nos dados.

Duas definições são utilizadas: na primeira, é construído um índice de tensão sócio-política, formado por indicadores de protesto político e violência social, os quais são aglutinados pelo método estatístico dos componentes principais. Na segunda, entra em conta o número de colapsos governamentais, ou de mudanças no poder executivo.

$O$ indice de instabilidade sócio-política tem explicado alguns fenômenos de natureza econômica, como o aumento da dívida externa em países em desenvolvimento. Resultados consistentes, obtidos de amostras abrangentes (tomando países de todos os continentes), mostram que países com maior estabilidade sócio-política são países com maiores indices de crescimento do produto. Melhor, analisando ao longo do tempo, as taxas de crescimento são maiores em anos sem golpes (ou mesmo sem mudanças de governo mais "leves") que em anos com golpes de Estado (ou com substituições do executivo).

Como conclusão, chega-se a um círculo vicioso: os paises pobres são, em sua maioria, sócio-politicamente instáveis. Uma vez que a instabilidade reduz incentivos ao investimento - por conseguinte, ao crescimento econômico, têm-se que os paises pobres são instáveis por não conseguirem tornar-se ricos, e não se tornam ricos por serem politicamente instáveis. Uma qualificação adicional deve ser colocada: os paises pobres são instáveis por não terem riqueza. Além da riqueza, os países desenvolvidos têm renda melhor distribuída, senão a instabilidade social também se faria presente.

Agregando as análises de regime político e instabilidade sócio-política com o crescimento econômico, pode-se concluir que este não é fortemente influenciado pela natureza do regime político (democracia ou ditadura). A 
estabilidade do regime, por outro lado, exerce influência muito mais positiva sobre o crescimento (ALESINA \& PEROTTI, 1994, p.359).

Finalmente, analisa-se a relação entre distribuição de renda e crescimento econômico, com enfoques políticos e de natureza mais puramente econômica.

Na maioria dos trabalhos elaborados desde Kuznets, a direção do elo vai do crescimento para a distribuição de renda, antes que desta para o crescimento. Assim, visualizam-se processos redistributivos apenas em contextos de crescimento econômico.

Estudos recentes buscam, por outro lado, antever os impactos de políticas redistributivas sobre o crescimento, ainda sob a ótica política. Dois canais são enfatizados: o fiscal e o da instabilidade.

Papel crucial desempenha a distribuição de renda inicial, a partir da qual são analisadas as políticas redistributivas. Na área fiscal, como uma das alternativas de redistribuição, recursos do governo serão gastos em infraestrutura. Dada a distribuição funcional da renda e supondo uma estrutura tributária progressiva, uma proporção relativamente maior do capital é taxada.

Assim, se os eleitores, em sua maioria, tiverem uma participação maior do capital no total de sua renda, certamente terão preferência por aquele programa de governo que, além de satisfazer outros anseios do eleitorado, menor ameaça possa representar em termos de tributação. No caso oposto, com a maioria dos eleitores tendo participação dominante de rendas do trabalho na renda total, a preferência será por programas de governo que enfatizem maior taxação progressiva. O resultado, no primeiro caso, será a menor tributação do capital, e portanto, maiores incentivos ao investimento e ao crescimento. Com uma maior tributação, menores serão o investimento e o crescimento econômico.

Existe, portanto, no canal fiscal, uma relação inversa entre a desigualdade da distribuição inicial dos recursos e a taxa de crescimento da 
economia. Quanto mais igualitariamente estiverem distribuídos os recursos, menores serão os incentivos à maior taxação do capital, e o investimento privado é estimulado. Como no caso da pesquisa relacionando regime político e crescimento, contudo, as análises quantitativas são bastante inconclusivas e não permitem afirmar inquestionavelmente essa relação inversa.

Já no canal da instabilidade, os resultados são mais consistentes. Dois elos estão presentes: o que vai da distribuição de renda à instabilidade política e o que vai desta ao crescimento econômico.

A idéia é que a desigualdade de renda é um importante determinante da instabilidade sócio-política. Países com distribuição de renda mais desigual são mais instáveis politicamente. Por seu turno, conforme exposto acima, a instabilidade política tem efeitos adversos sobre o crescimento. Assim, a busca por uma distribuição de renda menos desigual pode levar a um clima sóciopolítico mais estável, e por sua vez à maior taxa de crescimento da economia.

Esta foi a experiência de alguns países do sudeste asiático, entre eles Taiwan. Após a Segunda Guerra, as autoridades daquela nação promoveram uma reforma agrária, que tornou consideravelmente menos desigual tanto a distribuição de renda como da riqueza. Uma das consequências mais importantes foi a estabilidade política. A união destes efeitos não deixa dúvidas quanto ao papel que a redistribuição teve nas altas taxas de crescimento verificadas nas últimas décadas em Taiwan.

Assim, embora se tenha incerteza quanto aos efeitos de uma política fiscal redistributivista, há consenso quanto à redução das tensões sociais e quanto às consequências positivas que este contexto traz ao crescimento econômico. 


\subsection{3 - Impactos de uma Redistribuição de Renda no modelo de Kalecki}

Faz-se necessário resgatar as pressuposições do modelo kaleckiano. Em primeiro lugar, Kalecki trabalha com uma representação da realidade na qual há três grandes setores: produtor de bens de capital, produtor de bens de consumo dos capitalistas e produtor de bens de consumo dos trabalhadores.

É fundamental, em seu esquema de reprodução, a repartição do consumo em duas classes. Deve ser questionada a atualidade das categorias ou setores enunciados. Kalecki desenvolveu sua teoria entre os anos 30 e 60 deste século, sendo que grande parte de sua contribuição foi formalizada nos anos iniciais desse período. Pode-se dizer que, naqueles anos, a clara distinção entre capitalistas e trabalhadores era bastante apropriada. Os grandes desdobramentos da economia e da política nas décadas mais recentes, entretanto, têm promovido novas categorias econômicas e provocado envelhecimento de algumas antigas. Não seria assim ultrapassado falar na dicotomia capitalistas/trabalhadores?

Por um lado, a figura personificada do capitalista que está à frente do empreendimento, que busca as inovações, que gerencia seu próprio negócio, cada vez mais está sendo substituída pela figura impessoal da empresa capitalista. Por outro, a crescente complexidade administrativa nesta presente faz com que uma pequena parcela dos empregados receba rendimentos que parecem muito mais ter a ver com os lucros do que com os salários. São diretores, gerentes, chefes que ganham salários muito acima da média. Apesar de ser pequeno o número desses "trabalhadores" no total da mão-de-obra, é significativa a participação salarial dos mesmos na massa de salários. Neste sentido, o seu consumo tem mais a ver com o consumo capitalista do que com o consumo dos trabalhadores. 
Como trabalhar com o modelo kaleckiano na presença destes complicadores?

Em primeiro lugar, embora a evolução do capitalismo no decorrer dos anos tenha contribuído para dificultar a definição dos agentes econômicos como capitalistas ou trabalhadores, isso não significa que seja necessário modificar o modelo kaleckiano. Ele é construído a partir da existência de setores produtivos voltados para necessidades diferenciadas. É necessário enfatizar que mesmo quando escreveu sua teoria, o principal complicador residia em defender a existência desses setores produtivos distintos. Sabe-se que havia e há empresas que produzem para diversos agentes econômicos, sejam capitalistas ou trabalhadores.

Mesmo assim, supõe-se que não seja predominante a participação dessas empresas no total da produção, de forma que ainda é lícito assumir que há o setor que produz bens de capital (investimento), o que busca atender uma demanda diferenciada, voltada a classes de maior renda (bens de consumo capitalista) e o que se destina a atender o consumo de mercadorias básicas (bens de consumo dos trabalhadores).

Em termos agregados, a análise por departamentos apenas contribui para melhor visualizar as relações e os efeitos decorrentes de alterações na dinâmica do modelo.

A verdade é que nenhuma teoria tem por propósito espelhar a realidade em sua totalidade. Para que a teoria seja aceita, é necessário estabelecer pressupostos que, embora simplifiquem, não cheguem a distorcer a realidade.

Apenas será feita uma pequena adaptação à nomenclatura utilizada por Kalecki: o setor de bens de consumo dos capitalistas será chamado de bens de consumo de luxo, ficando inalterados os nomes do setores produtores de bens de capital e de bens de consumo dos trabalhadores.

Para se chegar às equações que refletem a distribuição de renda, é necessário desenvolver primeiro a equação dos determinantes dos lucros. 


\subsubsection{1 - A equação dos determinantes dos lucros}

Kalecki utiliza algumas hipóteses, para simplificar a exposição. Em sintonia com o que foi discutido acima, serão introduzidas pequenas modificações nessas pressuposições, que em nada alteram o raciocínio desenvolvido originalmente:

- apenas duas categorias de renda: lucros, incluindo aquelas rendas que a estes se assemelham, e salários;

- igualdade entre exportações e importações e inexistência de entrada e saída líquida de renda;

- orçamento governamental equilibrado;

- os trabalhadores não poupam, de modo que todo o montante de salários é gasto em consumo;

- a acumulação de estoques é computada como gasto em investimento, ou simplesmente inexiste;

- computa-se a produção, o lucro e o investimento em valores brutos, antes de deduzida a depreciação do capital fixo; e

- cada departamento produz não apenas os bens finais, mas também os bens intermediários que entram na composição dos bens finais.

Sempre que se faz necessário ampliar a análise para incluir atividades do Governo, transações externas, variação de estoques e poupança dos trabalhadores, abandona-se cada pressuposto respectivo (MIGLIOLI, 1981, p. 216).

Deve-se ter em mente que várias dessas hipóteses também estão presentes na teoria de Marx.

O pressuposto de que não há um departamento específico produtor de bens intermediários permite a construção de um modelo com apenas três 
setores: o de bens de investimento, 0 de bens de consumo de luxo e o de bens de consumo dos trabalhadores.

Conforme MIGLIOLI (1981, pp.218/219), o valor total da produção do departamento de bens de investimento (Dep.1) em determinado período de tempo - por exemplo, um ano - é igual a $I$. É também igual ao montante de salários pagos $\left(W_{1}\right)$ e lucros gerados $\left(P_{1}\right)$ nesse departamento no mesmo período. O departamento de bens de consumo de luxo (Dep.2) tem um valor de produção igual a $C_{l}$, correspondente à soma de $W_{2}$ e $P_{2}$, que é o montante de salários e lucros gerados nesse departamento. $O$ valor da produção do departamento de bens de consumo dos trabalhadores (Dep.3) é igual a $C_{w}$, correspondente a $W_{3}+P_{3}$, salários e lucros gerados no período no setor.

O Quadro 2 resume essas relações, onde o total de salários é representado por $W$ e o total de lucros por $P$. A renda nacional é denotada por $Y$.

\section{Quadro 2}

Produção e Renda Nacionais

\begin{tabular}{ccc|c}
\hline Dep.1 & Dep.2 & Dep.3 & Total \\
\hline$P_{1}$ & $P_{2}$ & $P_{3}$ & $P$ \\
$W_{1}$ & $W_{2}$ & $W_{3}$ & $W$ \\
\hline$I$ & $C_{1}$ & $C_{w}$ & $Y$ \\
\hline
\end{tabular}

Fonte: MIGLIOLI (1981, p.219)

Horizontalmente, temos:

lucro total

salário total

renda nacional

$$
\begin{aligned}
& P=P_{1}+P_{2}+P_{3} \\
& W=W_{1}+W_{2}+W_{3} \\
& Y=I+C_{l}+C_{w}
\end{aligned}
$$


Verticalmente:

produção do Dep.1 $\quad I=P_{1}+W_{1}$

produção do Dep.2 $\quad C_{1}=P_{2}+W_{2}$

produção do Dep.3 $\quad C_{w}=P_{3}+W_{3}$

renda nacional $\quad Y=P+W$

Utilizando as duas equações de renda nacional, temos:

$$
P+W=1+C_{1}+C_{w}
$$

Considerando a hipótese de que os trabalhadores não poupam, ou seja, gastam todo o seu salário na compra de bens de consumo dos trabalhadores (produção do Dep.3), tem-se $W=C_{w}$. Dessa forma, cancelando estas duas variáveis da equação acima, encontramos:

$$
P=I+C_{l}
$$

ou seja, o lucro total é igual ao investimento mais o consumo de bens de luxo, ou ainda, igual à produção dos Departamentos 1 e 2. Torna-se necessário qualificar este resultado.

Conforme MIGLIOLI (1981, p.221), o senso comum leva a interpretar que o lucro é dividido em investimento e consumo dos bens de luxo. No cotidiano, as pessoas auferem uma renda (suponha-se que seja o lucro) e, ao gastaremna, realizam investimentos e consumo de mercadorias. Por que não se poderia interpretar a equação dos lucros desta forma?

Kalecki sustenta que, quando se pensa na economia como um todo, inverte-se o sentido da determinação: são o investimento e o consumo dos bens de luxo que geram o lucro, e não o contrário.

As empresas e os empresários podem efetivamente decidir quanto vão gastar, mas não que lucro vão ter. A determinação dos lucros se dá no mercado, quando se efetivam as vendas. Se a demanda não é suficiente para 
absorver os produtos ofertados, o lucro potencial não se realiza plenamente. Por outro lado, os gastos que podem realmente realizar determinam o lucro total da economia. Quanto maiores forem o investimento e o consumo de bens de luxo, maior será esse lucro. Por qual motivo o setor de bens de consumo dos trabalhadores não participa da determinação dos lucros?

Se se supõe que o valor da produção da economia como um todo está crescendo apenas em virtude do crescimento da produção do setor de bens de consumo dos trabalhadores, isto significa que os lucros do Dep.3 estão crescendo. Também significa que os trabalhadores dos outros dois departamentos estão consumindo mais, o que pressupõe maiores salários. Ora, se a produção desses dois setores não se altera, é claro que os lucros nestes são menores, na proporção do aumento verificado nos lucros do Dep.3. Ocorre, portanto, um deslocamento de parte dos lucros dos Departamentos $1 \mathrm{e}$ 2 para o Departamento 3. Na economia como um todo, o lucro não se altera.

\subsubsection{2 - Distribuição de renda na determinação dos salários e da renda nacional}

No modelo kaleckiano, o investimento e o consumo de bens de luxo determinam o montante de lucros da economia. A determinação da renda nacional e do total de salários também depende do comportamento dessas duas variáveis, mas adicionalmente da variação da distribuição de renda. Se é dada esta distribuição, a renda nacional e os salários dependerão apenas dos gastos em investimento e bens de consumo de luxo. Se, entretanto, varia a distribuição de renda, quais os impactos sobre aqueles agregados?

A distribuição de renda pode ser interpretada pelo seu aspecto funcional, como a participação dos salários na renda, conforme discutido no Capítulo 1. Assim, $w=W / Y$, onde $w$ é a distribuição de renda, $W$ é o total de 
salários e $Y$ é a renda nacional. Para os três setores do modelo de Kalecki, tem-se $w_{1}=W_{1} / l, W_{2}=W_{2} / C_{1}$ e $W_{3}=W_{\mathfrak{J}} / C_{w}$, que representam a participação salarial na renda dos Departamentos 1,2 e 3.

Sabe-se que o lucro do Departamento 3 é:

$$
\begin{aligned}
& P_{3}=C_{W}-W_{3} \\
& P_{3}=W_{1}+W_{2}+W_{3}-W_{3} \\
& P_{3}=W_{1}+W_{2}
\end{aligned}
$$

Representemos os salários dos três departamentos como sendo: $W_{1}=\frac{W_{1}}{l} . l ; \quad W_{2}=\frac{W_{2}}{C_{l}} C_{l}$ e $W_{3}=\frac{W_{3}}{C_{W}} . C_{W_{3}}$, onde $\frac{W_{1}}{l} \frac{W_{2}}{C_{l}}$ e $\frac{W_{3}}{C_{w}}$ representam a participação dos salários na renda de cada departamento.

Utilizando (2),

$$
\begin{aligned}
& P_{3}=C_{w}-W_{3} \\
& P_{3}=C_{w}-\frac{W_{3}}{C_{w}} \cdot C_{w} \\
& P_{3}=\left(1-\frac{W_{3}}{C_{w}}\right) \cdot C_{w}
\end{aligned}
$$

A equação (3) pode, portanto, ser escrita como:

$$
\left(1-\frac{W_{3}}{C_{w}}\right) \cdot C_{w}=\frac{W_{1}}{l} \cdot l+\frac{W_{2}}{C_{l}} \cdot C_{l}
$$

Utilizando a notação acima definida, tem-se:

$$
\left(1-w_{3}\right) \cdot C_{w}=w_{1} \cdot I+w_{2} \cdot C_{1}
$$

Dessa forma, o consumo dos trabalhadores, igual ao total de salários, é:

$$
C_{w}=\frac{w_{1} \cdot l+w_{2} \cdot C_{l}}{1-w_{3}}
$$


Uma vez que a renda nacional, $Y$, é igual à soma do investimento, consumo dos bens de luxo e consumo dos trabalhadores, obtém-se, da equação (4),

$$
Y=I+C_{1}+\frac{w_{1} \cdot I+w_{2} \cdot C_{l}}{1-w_{3}}
$$

Kalecki supõe dada a distribuição de renda, de forma que pode concluir que a determinação dos salários e da renda nacional, bem como dos lucros, dependem do comportamento do investimento e do consumo de bens de luxo. Quanto maiores forem estes agregados, maiores serão a renda nacional e o consumo dos trabalhadores.

Se, entretanto, se supuser que varia a participação dos salários na renda, qual será o comportamento das demais variáveis, inclusive as independentes, que são o investimento e o consumo dos bens de luxo?

Primeiramente, veja-se a equação (4). Caso aumente a participação dos salários na renda gerada em cada departamento, sendo dados o investimento e o consumo dos bens de luxo, maior será o consumo dos trabalhadores, e o contrário no caso de queda na participação salarial. Este resultado não traz nada de novo, uma vez que uma redistribuição em favor dos salários resulta automaticamente em maior consumo dos trabalhadores, ainda mais porque está-se supondo que os mesmos não poupam. Ainda que se retire esta hipótese restritiva, a propensão a poupar dos trabalhadores só é significativa para os salários mais altos, de forma que conduz à mesma tendência encontrada no caso de ausência de poupança dos trabalhadores.

Embora a equação (5) tenha o mesmo comportamento da equação (4) se, como anteriormente, considerarem-se dados o investimento e o consumo dos bens de luxo, o efeito de uma redistribuição dos rendimentos sobre a renda 
nacional não é tão intuitivo. É claro que com um total de salários maior, haverá maior demanda por bens de consumo dos trabalhadores, o que por sua vez incentiva maior produção do Departamento 3 , que muito provavelmente ampliará seus investimentos, todos estes fatores contribuindo para o aumento da renda nacional. Ocorre que, tanto no caso da equação (4) como da (5), não se pode considerar dados o investimento e o consumo dos bens de luxo. E aí, - resultado poderá ser diferente, conforme for o comportamento dessas variáveis em vista da efetivação de um deslocamento da renda em favor dos salários.

Conforme KALECKI (1977, p.92), a teoria clássica conclui que qualquer ganho salarial deprime os lucros, ocorrendo, portanto, uma redistribuição efetiva de renda. Ele vem, contudo, provar o contrário.

Mantendo as hipóteses de seu modelo, já expostas, Kalecki supõe uma elevação proporcional de todas as faixas de salário. O contexto é de um curto espaço de tempo. Uma vez que o investimento e o consumo dos bens de luxo são decididos antes do momento em que ocorre o aumento salarial, segue-se que não são afetados, pelo menos durante o periodo de tempo definido.

Recordando a economia de três setores, tem-se que o aumento salarial dos Departamentos 1 e 2 resulta em lucro adicional do Dep. 3, uma vez que os trabalhadores gastam todo o seu salário. Nesse último setor, como os lucros adicionais provenientes dos maiores gastos de seus trabalhadores são a contrapartida do aumento salarial anteriormente pago, segue-se que estes movimentos se compensam.

Nos Departamentos 1 e 2, entretanto, o ganho salarial gera lucros menores, pois a teoria clássica está supondo que os preços não são alterados. Sejam $W_{1}$ e $W_{2}$ as folhas de salários nesses setores. $O$ acréscimo do montante salarial é representado por $\alpha\left(W_{1}+W_{2}\right)$. Os lucros caem na mesma proporção deste aumento, passando a ser: $P_{1}+P_{2}-\alpha\left(W_{1}+W_{2}\right)$. Os lucros totais, por outro lado, não se alteram, lima vez que essas perdas transferem-se todas 
para o Dep. 3. Na economia como um todo, portanto, chega-se à conclusão de que não ocorre qualquer redistribuição de renda dos salários para os lucros.

Os maiores lucros no Departamento 3 podem ser a contrapartida tanto de um aumento da produção como de um aumento de seus preços, ou de ambos.

Poder-se-ia argumentar que o investimento e o consumo dos bens de luxo, embora se mantenham constantes no curto período de tempo considerado, poderiam ser reduzidos em momento imediatamente posterior. Isto faria com que diminuísse a renda nacional. $\mathrm{Na}$ economia como um todo isso não ocorre, pois, como foi demonstrado, os lucros totais permanecem inalterados. Se a decisão de cortar investimentos ou consumo de bens de luxo não ocorrer logo que sobem os salários, muito provavelmente não ocorrerá depois.

O mesmo resultado, vice-versa, ocorre no caso de uma perda salarial. Não se efetiva qualquer redistribuição dos rendimentos.

Estas conclusões são tiradas no contexto pressuposto pela economia clássica - na teoria da transferência dos lucros para os salários - de concorrência perfeita. Ainda mantendo este contexto (embora Kalecki o considere extremamente irrealista), deve-se perguntar o que acontece se os preços forem reajustados em virtude do aumento salarial, pois este é o caso mais provável.

Maiores salários devem levar a maiores preços, dadas as conhecidas curvas de demanda e oferta do modelo perfeitamente concorrencial, com inclinações contrárias e se interceptando em algum ponto. Como no caso anterior, o aumento salarial não altera o volume do investimento e do consumo dos bens de luxo. Como os trabalhadores gastam todo seu salário, desloca-se a curva de demanda para cima e à direita, encontrando novo ponto de equilíbrio a preço mais elevado. O aumento de preços é proporcional à elevação salarial. Logo, nos Departamentos 1 e 2 a produção permanece a 
mesma, mas os preços de seus produtos são reajustados a fim de compensar os maiores gastos com os assalariados. O mesmo ocorre no Dep. 3, e ademais, os gastos adicionais dos trabalhadores dos dois primeiros setores em bens de consumo são absorvidos pelos maiores preços praticados por esse departamento.

Desta forma, os salários em todos os setores foram reajustados, passando a valer $1+\beta$, com $\beta=\alpha\left(W_{1}+W_{2}+W_{3}\right)$. Os preços em toda a economia também foram reajustados, resultando num acréscimo também igual a $\beta$. Ou seja, a produção global não se altera, apenas fica mais cara, no valor igual a $1+\beta$. Como os trabalhadores também tiveram seu salário incrementado na mesma medida, conclui-se que, também neste caso, não ocorre redistribuição dos rendimentos.

Por sua vez, os lucros no Dep. 3 são maiores, na exata medida do aumento salarial nos Departamentos 1 e 2 , igual a $\beta$. Esses lucros serão gastos, não se sabe se totalmente, em novos investimentos e/ou consumo de bens de luxo, em momento posterior. Uma vez que os preços desses bens também foram reajustados em $\beta$, completa-se o circuito sem que tenha ocorrido redistribuição de renda entre lucros e salários.

Esse contexto de concorrência perfeita, como se sabe, não é aplicável à economia como um todo. Kalecki rejeita-o, afirmando que a concorrência, desde tempos remotos do capitalismo, sempre foi muito desigual (KALECKI, 1977 , p. 94). Reconhece, entretanto, que as matérias-primas básicas são produzidas e comercializadas em condições de concorrência perfeita. Dessa forma, a economia de um país caracteriza-se por produzir em condições de oligopólio diferencial, coexistindo com alguns monopólios e com a concorrência perfeita em setores bastante específicos.

A evolução da economia mundial tem revelado um aprofundamento da configuração dos mercados em oligopólios. Dificilmente se encontra um grande grupo operando em condições de monopólio. Na era da globalização, 
sobressaem-se a concorrência acirrada, a dificuldade em manter barreiras à entrada de outros grandes grupos no negócio e a supremacia de empresas de grande porte na economia. Se nos tempos em que Kalecki escreveu "Luta de Classe e Distribuição da Renda Nacional", nos anos finais da década de 60, o oligopólio era a organização empresarial mais expressiva, não há motivos para supor que, atualmente ou nos próximos anos, haja espaço para outra forma de organização dos mercados que não seja predominantemente oligopólica .

O modelo que poderia melhor se adaptar à realidade econômica seria, segundo esse autor (KALECKI, 1977, p.96), portanto, outro. As grandes empresas fixam o preço de seus produtos com base nos seus custos primários - custos médios de salários mais os de matérias-primas - acrescentando uma margem (mark-up) a fim de obter lucros e cobrir as demais despesas, chamadas por Kalecki de overheads (despesas com aluguéis, com pessoal administrativo etc.). Esse acréscimo, entretanto, não pode ser fixado pela empresa sem restrições. O preço médio observado no mercado em que atua terá de ser levado em consideração, se deseja participar desse mercado.

A equação que representa o modelo baseado em oligopólios para uma empresa (KALECKI, 1977, p.96) é a seguinte:

$$
\frac{p-u}{u}=f(p * / p)
$$

com:

$p=$ preço a ser fixado levando em conta o preço médio ponderado

$u=$ custo primário (custos médios de salários mais os de matériasprimas)

$p^{*}=$ preço médio de mercado ponderado

$\mathrm{p}=$ preço baseado apenas nos custos primários

$f=$ função que leva em consideração a relação entre o preço médio de mercado ponderado e o preço da empresa baseado nos custos 
Da maneira como está colocada, a fórmula apenas diz que o mark-up (dado pela parte à esquerda da igualdade) é fixado em função da relação entre os preços da firma e do mercado. Cabe acrescentar que a função $f$ é crescente: quanto menor for $p$ em relação a $p^{\star}$, maior será o acréscimo fixado. Trabalhando com a equação (6), obtém-se:

$$
p=u\left[1+f\left(p^{\star} / p\right)\right]
$$

A função $f$ reflete as influências semimonopolísticas presentes. Quanto maior for o poder da empresa em fixar o preço para seus produtos, maior será $f\left(p^{*} / p\right)$, correspondente a dada relação $p^{*} / p$.

Os preços $p$ são, em geral, diferentes para cada empresa dentro de uma indústria (entendida como o mercado para o produto em questão), em virtude das diferenças nos custos primários $u$ e nas funções $f$.

O sistema de preço é determinado (KALECKI, 1977, p.96), uma vez que, supondo a existência de $s$ firmas no mercado, haverá $s+1$ preços a serem encontrados $\left(p_{1}, p_{2}, \ldots, p_{\mathrm{s}}, p^{\star}\right)$ e o mesmo número de equações: $s$ do tipo (7) e uma determinando $p^{*}$ em função de $p_{1}, p_{2}, \ldots, p_{\mathrm{s}}$.

Quando se supõe que ocorre um acréscimo nos custos primários - um aumento salarial em todas as empresas desse mercado oligopólico, por exemplo - a relação $p^{*} / p$ não se altera, pois todas as empresas alteram seus preços na proporção do aumento salarial (mantendo inalterada a relação de preços da indústria), de forma que $p^{*}$ também aumenta na mesma magnitude. Se a relação não se altera, e supondo que a funcão $f$ também permaneça a mesma, o acréscimo nos salários é transferido para os preços, resultando que não ocorre nenhuma redistribuição da renda, mais uma vez.

A função $f$ pode, entretanto, sofrer alteração, o que inevitavelmente resulta numa transferência de renda. KALECKI (1977, pp. 97-98) prevê que aquelas empresas que possuem mark-up's elevados sofrerão pressão por parte de seus empregados, visando elevação dos salários. Conforme exposto, a 
empresa oligopólica repassará para os preços este gasto adicional. Aquelas categorias profissionais com sindicatos fortes continuarão, contudo, a exigir maiores salários, levando as empresas a uma situação em que não será mais viável reajustar preços, em virtude da concorrência. Com isso, os acréscimos representados pelos valores $f(p * / p)$ serão menores do que seriam caso não houvesse limite para reajustes de preços. Ocorre, desta forma, uma redistribuição de renda, dos lucros para os salários. Por outro lado, essa redistribuição seria muito maior se não fosse possível às empresas reajustar preços.

Conforme visto no capitulo anterior, ocorreu de fato no Brasil uma pequena redistribuição dos rendimentos, decorrente de pressão sindical, no final da década de 70 .

Como ocorre essa redistribuição de renda e quais seus impactos sobre a economia como um todo, no modelo kaleckiano?

Os salários são reajustados em todos os departamentos, correspondendo a um acréscimo de $\alpha\left(W_{1}+W_{2}+W_{3}\right)$ em seu montante. Os preços também são reajustados, mas numa porcentagem inferior à do aumento salarial, por exemplo, em $\delta \operatorname{com} \alpha>\delta$. Nos Departamentos 1 e 2, o aumento salarial concedido, cujo montante é de $\alpha\left(W_{1}+W_{2}\right)$, é totalmente gasto em bens de consumo dos trabalhadores, revertendo em maiores lucros para 0 Departamento 3, em igual proporção. Os lucros desses departamentos (1 e 2), entretanto, não caem na mesma medida, uma vez que ocorreu um acréscimo em seus preços, ainda que inferior ao concedido aos salários. Suponha-se que o reajuste de preços eleva as receitas totais em $\delta\left(W_{1}+W_{2}\right)$. A queda nos lucros dos Departamentos 1 e 2 é, portanto, igual a $(\alpha-\delta)\left(W_{1}+W_{2}\right)$.

O Departamento 3 revela uma dinâmica própria, por estar produzindo bens de consumo para os trabalhadores. Aqui, o reajuste de salários retorna sob a forma de lucros, de maneira que, como anteriormente, não afeta seu montante. $O$ crescimento dos lucros nesse setor é, portanto, igual a $\alpha\left(W_{1}+\right.$ 
$W_{2}$ ). Os preços dos bens de consumo dos trabalhadores sofreram reajuste igual a $\delta$. Isto significa que o poder de compra dos trabalhadores aumentou, no montante de $(\alpha-\delta)\left(W_{1}+W_{2}+W_{3}\right)$. Dado que os preços não sobem além de $\delta$, essa pressão de demanda resolve-se por meio de um aumento da produção do Departamento 3. Ocorre, desta forma, um aumento do emprego nesse setor, junto a uma maior utilização da capacidade produtiva. $O$ modelo baseado em oligopólios pressupõe, realisticamente, a existência de capacidade ociosa.

Essa maior produção de bens de consumo dos trabalhadores deverá provocar um aumento dos preços das matérias-primas básicas, sujeitos ao regime de concorrência perfeita. Assim, os preços dos bens produzidos no Departamento 3 poderão, num segundo momento, subir além de $\delta$, o que restringiria em parte o aumento do emprego e da produção. O que ocorre com os lucros e com a produção da economia como um todo?

Os lucros caem nos dois primeiros departamentos e crescem no terceiro. Procedendo à diferença, $\alpha\left(W_{1}+W_{2}\right)-(\alpha-\delta)\left(W_{1}+W_{2}\right)$, chega-se ao resultado dos lucros totais: $+\delta\left(W_{1}+W_{2}\right)$. Chega-se, portanto, ao surpreendente resultado de que uma redistribuição de renda dos lucros para os salários resulta em crescimento dos lucros totais.

A produção cresce no Departamento 3, como visto. Nos outros dois setores, entretanto, permanece inalterada, pois como anteriormente, não há motivos para um corte no investimento ou no consumo de bens de luxo. No curto prazo, a maior produção de bens de consumo dos trabalhadores dar-se-á através de maior utilização da capacidade produtiva. O efeito de uma redistribuição dos rendimentos deverá, no longo prazo, incentivar os investimentos totais, uma vez que há perspectivas de se efetivar um novo padrão de consumo, com uma elevação no patamar da propensão a consumir. A maior atividade no Departamento 3, portanto, resultará em maiores encomendas junto aos dois primeiros departamentos, vale dizer, serão estimulados o investimento e a produção de bens de consumo de luxo 
Ademais, deve-se lembrar que, nesse modelo, os lucros totais são determinados pelo investimento e pelo consumo dos bens de luxo (pp. 86-87), de forma que, se foi provado que os lucros totais crescem em $\delta\left(W_{1}+W_{2}\right)$, esse movimento decorre de maiores gastos em investimento e consumo dos bens de luxo.

Keynes não deixa lugar à dúvida acerca do incentivo que um aumento da propensão a consumir pode trazer ao investimento. Na discussão sobre os fatores objetivos da propensão a consumir, afirma: "O obstáculo que se antepõe a um claro entendimento destas questões parece constituir-se, como sucede na maioria das discussões acadêmicas sobre o capital, de uma apreciação inadequada do fato de que o capital não é uma entidade que subsista por si mesma, independentemente do consumo. Pelo contrário, cada enfraquecimento na propensão a consumir, considerada como hábito permanente, leva a demanda de capital a enfraquecer-se juntamente com a demanda de consumo." (KEYNES, 1985, p.81)

No Livro Sexto, que se intitula "Breves Notas Sugeridas pela Teoria Geral", o último capítulo retoma o assunto das relações entre consumo e investimento, agora sob a ótica de uma redistribuição dos rendimentos. Repete-se aqui trecho que já consta em nota de rodapé (p.90). "Ademais, a experiência ensina que, nas condições existentes, a poupança por meio de instituições e de fundos de amortização è mais que adequada, e que as medidas destinadas a redistribuir a renda no sentido de aumentar a propensão a consumir podem ser muito favoráveis ao crescimento do capital." (KEYNES, 1985, p.253)

Seguindo, "Mas, como um aumento da propensão habitual a consumir contribui, em geral (isto é, excetuando as condições de pleno emprego), para elevar o incentivo ao investimento, a conclusão que daí se tira é quase sempre oposta à verdade." (KEYNES, 1985, p.254) Esta conclusão errônea a que Keynes se refere é "A crença tão generalizada de que os impostos sobre 
heranças são responsáveis pela redução da riqueza de capital de um país...". (KEYNES, 1985, p.253)

Keynes não prossegue sua argumentação defendendo deliberadamente uma redistribuição dos rendimentos, mas defende que um determinado grau de desigualdade dos rendimentos é propício à atmosfera que leva aos investimentos, embora considerasse exageradas as disparidades existentes à época na Inglaterra. (KEYNES, 1985, p.254)

Conclui-se que uma redistribuição de rendimentos dos lucros para os salários, além de contribuir para o aumento dos lucros totais, estimula o investimento e o consumo dos bens de luxo, que são as variáveis fundamentais da dinâmica capitalista. Deve-se ter em mente que se chegou a estes resultados através da utilização de um modelo baseado em oligopólios, com suposições realistas, entre as quais a possibilidade de que os preços podem subir em resposta aos aumentos salariais.

\section{2 - Algumas propostas redistributivistas}

As discussões realizadas neste item procuram mostrar propostas com o objetivo de redistribuir a renda nacional em favor dos que auferem menores rendimentos, e que estão na ordem do dia. Como será visto, nenhuma delas trata diretamente da redistribuição dos lucros para os salários. Seria isto um complicador, dado que toda a parte teórica desenvolvida neste capítulo baseiase em alterações ocorridas na distribuição funcional da renda?

Deve ficar claro que os estratos de renda localizados na parte superior da distribuição são constituídos, com poucas exceções, por rendimentos que não se classificam como salários. Da mesma forma, os estratos inferiores compõem-se basicamente de salários. Assim, quando se fala em redistribuição favorável aos que menos ganham, está-se, indiretamente, tratando de um 
processo cujos efeitos alteram a relação lucros/salários, em benefício do denominador desta relação.

\subsection{1 - Investimentos em Educação}

No longo prazo, medida que desponta como primordial na consecução de um programa de redistribuição de renda diz respeito ao papel da educação.

Desde o inicio da controvérsia, no começo dos anos 70, a respeito das interpretações do intenso processo de concentração da renda verificado na década anterior, muitos economistas têm se dedicado a estudar a influência exercida pela educação no aumento no grau de desigualdade da distribuição.

Quase sempre o poder explicativo dessa variável nas oscilações da desigualdade da renda (que é a variável dependente) supera o das demais, quais sejam diferenças de idade, situação ocupacional, indice de desemprego, variação no salário mínimo etc. Assim, não há como negar a importância da educação (tomada como proxy do nível de qualificação) na geração de desniveis salariais, num primeiro instante, e de desigualdade, em última análise.

O que pode ser questionado é que há circularidade neste argumento. Por um lado, níveis de educação diferentes levam a aumentos no grau de desigualdade; por outro, a própria desigualdade da renda tem influência muito forte na seleção dos indivíduos que terão acesso a melhores níveis educacionais. Sabe-se que as oportunidades educacionais no Brasil não são as mesmas para todos os indivíduos. Pelo contrário, quanto maior o nível social, e portanto os rendimentos, maiores as chances de melhor formação educacional. Numa sociedade com disparidades brutais de renda, sem que haja um programa educacional integrado, a partir do ingresso das crianças nos bancos escolares, até a formação de nível superior, dificilmente conseguir-se-á gerar uma sociedade mais igualitária no longo prazo. 


\subsubsection{1 - Diagnóstico da situação presente}

Dados comprovam que $\bigcirc$ acesso à educação melhorou consideravelmente desde 1950. Nessa época, a rede de ensino básico atendia apenas $36,2 \%$ da população com idade entre 7 e 14 anos. Hoje, cerca de 35 milhões de estudantes são "atendidos", o que representa $92 \%$ da população naquela faixa de idade. Persistem, contudo, sérios problemas relacionados à qualidade do ensino e à permanência do aluno na escola até a conclusão das várias etapas do sistema educacional.

Quanto à qualidade, a última pesquisa do Sistema Nacional de Avaliação da Educação Básica (SAEB), realizada em 1995 pelo Ministério da Educação, revela a precariedade do conteúdo educacional dos alunos no Brasil. A avaliação de desempenho contemplou as matérias de Língua Portuguesa e Matemática. Foram avaliados 124.870 alunos da $4^{\mathrm{a}}$ e $8^{\mathrm{a}}$ séries do $1^{\circ}$ grau e da $2^{a}$ e $3^{a}$ séries do $2^{\circ}$ grau, nos 27 estados da Federação. Foram propostos, no total, 1.236 itens para serem respondidos pelos alunos. Pela primeira vez, a pesquisa do SAEB abrangeu também as escolas particulares. Os resultados são desanimadores, conforme mostra a Tabela 27.

Tabela 22

Índice de Acertos - Pesquisa do SAEB - 1995 (\%)

Série

$4^{\text {a }}$ série do $1^{\circ}$ grau

$8^{\mathrm{a}}$ série do $1^{\circ} \mathrm{grau}$

$2^{\mathrm{a}}$ série do $2^{\circ}$ grau

$3^{\mathrm{a}}$ série do $2^{\circ}$ grau
Língua Portuguesa

50,60

63,04

43,40

61,28
Matemática

38,30

41,16

22,20

33,76

Fonte: MEC (1996), em Gazeta Mercantil, 22.03.1996 
Em primeiro lugar, o mito da excelência do ensino nas escolas particulares fica seriamente abalado. A segunda constatação é que o aproveitamento escolar deixa muito a desejar, especialmente em matemática. Às vésperas do vestibular, o aluno continua tendo muita dificuldade para assimilar os conceitos matemáticos. A prova de Língua Portuguesa, que avalia a compreensão de texto escrito, também revela resultados abaixo das expectativas. Comprova que há deficiências no ensino básico, comprometendo o rendimento do aluno até mesmo no ensino médio ( $\left.2^{\circ} \mathrm{grau}\right)$.

A repetência é outro problema grave presente. De cada mil alunos que ingressam na $1^{\mathrm{a}}$ série do $1^{\circ} \mathrm{grau}, 400$ repetem.

Os dados sobre abandono da escola também são incontestáveis. Apenas $58 \%$ desses que iniciam o $1^{\circ}$ grau chegam até a $4^{\mathrm{a}}$ série, gastando um tempo médio de 6,2 anos. Chegam à $8^{\text {a }}$ série apenas $43 \%$, depois de um tempo médio de 11 anos na escola. No $2^{\circ}$ grau, cerca de 4,5 milhões de alunos são atendidos, mas a população de jovens com idade entre 15 e 19 anos é de 16 milhões.

O alto grau de abandono é um dos principais responsáveis pela taxa de analfabetismo, que ainda é alta, a despeito dos investimentos em educação nas últimas décadas, que proporcionaram o acesso à escola a um enorme contingente de pessoas. Em 1950, 50,6\% da população era analfabeta; em 1991 , esse índice era de $20,07 \%$ na população maior de 15 anos. A redução do analfabetismo não acompanhou a evolução da ampliação do acesso à educação. Muitos recursos foram desperdiçados ou mal direcionados, caso contrário a taxa de analfabetismo seria hoje residual.

Com a Constituição de 1988 , os estados e municípios devem gastar o equivalente a $25 \%$ de sua arrecadação com a educação. Não são definidas, entretanto, as responsabilidades nesse gasto. Dessa forma, até mesmo uma estrada que passe em frente a uma escola pode ser financiada com verbas educacionais. 
Para evitar esses desvios, tramita no Congresso projeto do governo que estabelece que $60 \%$ do gasto em educação, previsto pela Constituição (correspondente a $15 \%$ do total arrecadado), deve ser alocado com salários dos professores. Em alguns municipios, principalmente no interior do Nordeste, a remuneração do professor não chega a meio salário mínimo. A recuperação do ensino básico passa pela revalorização do educador.

Outra distorção do sistema educacional brasileiro é a alocação de recursos, fortemente favorável ao ensino superior. Em 1995, foram gastos $\mathrm{R} \$$ 5,2 bilhões com o ensino universitário. Nessa cifra incluem-se despesas com manutenção de 48 hospitais. Por outro lado, com o combate ao analfabetismo foram gastos, em 1995, R\$ 17 milhões.

O governo federal tem outras propostas de melhoria do ensino básico, além daquela que visa revalorizar a profissão do professor. Para $01^{\circ} \mathrm{grau}$, a pré-escola deverá ser incorporada ao ensino fundamental, passando este a ter a duração de nove anos, ao invés dos oito atuais. O segundo grau permitirá maior expressão da individualidade do aluno, pois este contribuirá para a escolha parcial das matérias que deverá cursar. A idéia é inspirada na experiência francesa e prevê que o primeiro ano, básico, será comum para todos os alunos. No segundo, as disciplinas obrigatórias (Língua Portuguesa, Matemática, História, Geografia, Física e Quimica) deverão responder por 70\% da carga horária, e no terceiro e último ano por $50 \%$. O tempo de aula que restar deverá ser preenchido pelo aluno através da escolha entre cinco grandes áreas de conhecimento: Ciências da Vida, Arte e Comunicação, Ciências Exatas e Informática, Ciências Sociais e Ciências Econômicas. 


\subsubsection{2 - A importância da educação como determinante da qualificação do trabalhador}

A abertura da economia brasileira à concorrência internacional tem mostrado, com muita clareza, que o padrão competitivo exigido pela economia da era da informação necessita de mão-de-obra especializada, com um conteúdo educacional que deve ser tanto maior quanto mais qualificada for a função a ser exercida.

Não é por outra razão que empresas como a Robert Bosch, Caraíba Metais, Companhia Siderúrgica Nacional (CSN), Tubos e Conexões Tigre etc., têm investido no reforço educacional de seus empregados. Em alguns casos, o objetivo é fazer com que todos os trabalhadores possuam até o primeiro grau completo; em outros, o segundo grau; cursos de especialização industrial, de rápida duração, também são amplamente utilizados.

De qualquer forma, investimentos públicos ou privados para um maior reforço do ensino básico ( $\left.1^{\circ} \mathrm{grau}\right)$, como do ensino técnico são pré-condições para que o Brasil consiga se manter dentro da concorrência imposta pela globalização dos mercados.

Um relatório do Banco Mundial (1995) confirma a importância da educação como um determinante do aumento da qualidade e da produtividade na atividade econômica. A China, onde os trabalhadores auferem baixos salários, tem outra vantagem comparativa relativamente a outros países grandes, pobres e populosos. Numa comparação da atividade rural, a introdução de grãos de alta produtividade na província chinesa de Hunan deu bons resultados; na Índia, nem tanto. A diferença não foi de solo ou clima, mas de formação educacional. A China tem uma taxa de analfabetismo de $27 \%$, ao passo que, na Índia, esse indicador é de quase o dobro - $52 \%$. 
Outra abordagem interessante refere-se aos impactos salariais decorrentes de diferentes graus de escolaridade. Os Gráficos 12 e 13 resumem essas relações.

\section{Gráfico 12}

Número de salários-base* ganhos por trabalhadores (homens) com diferentes graus de escolaridade

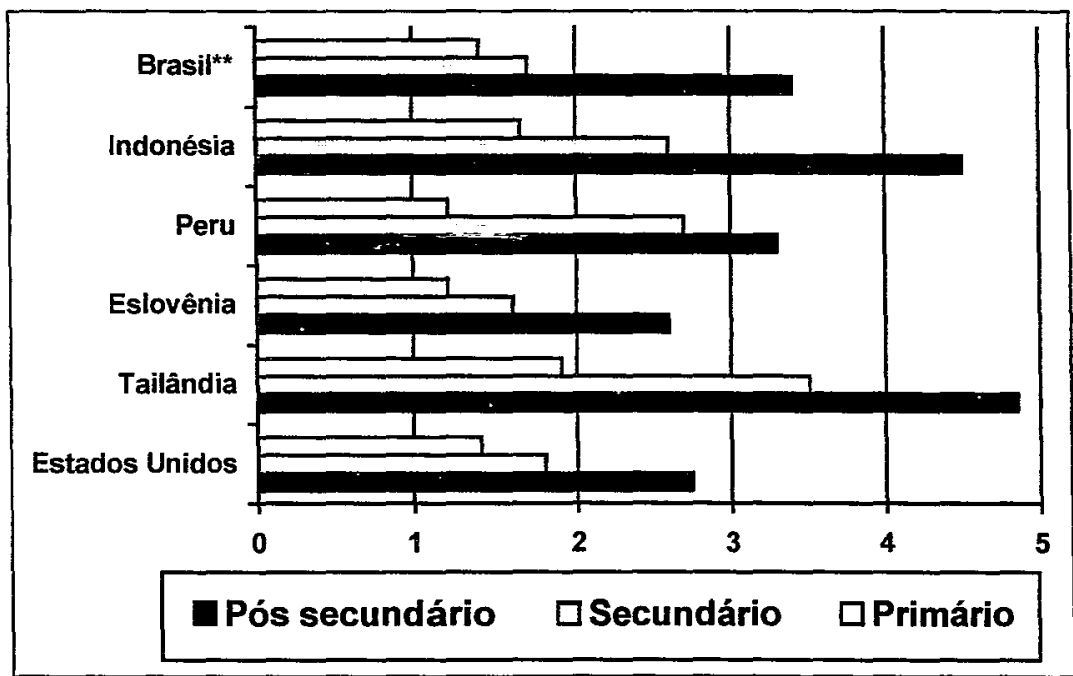

Fonte: Banco Mundial (1995)

* Referente à remuneração de um trabalhador sem escolaridade ** Dados para o Brasil incluem mulheres e a fonte é PSACHAROPOULOS $(1992$, p.15) 


\section{Gráfico 13}

Número de salários-base* ganhos por trabalhadores (mulheres) com diferentes graus de escolaridade

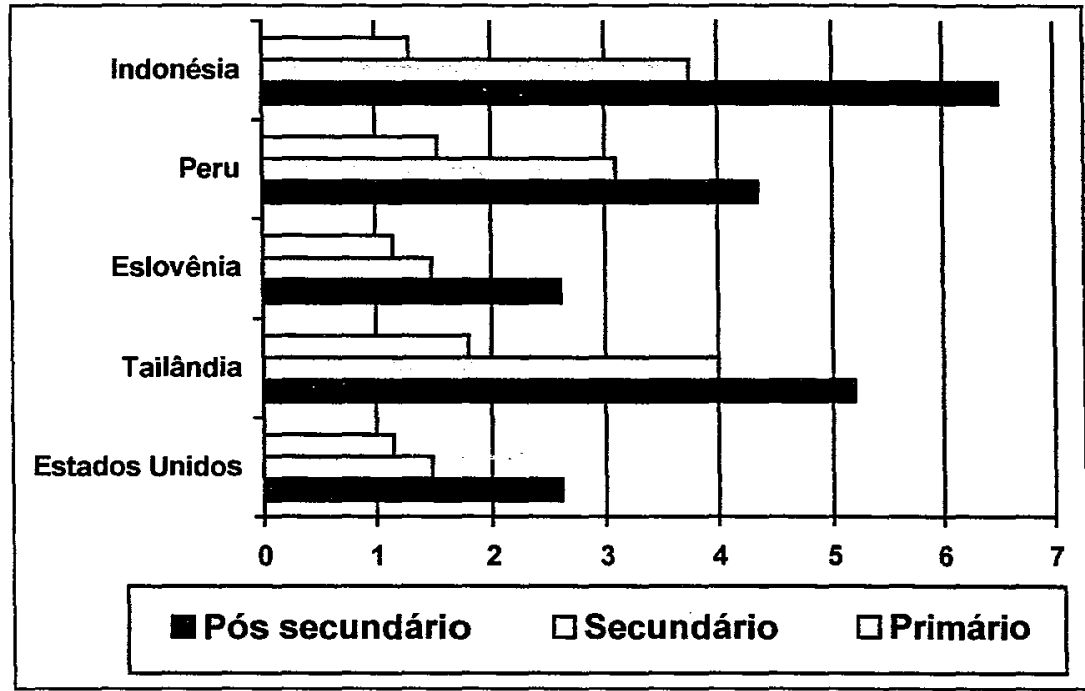

Fonte: Banco Mundial (1995)

* Referente à remuneração de um trabalhador sem escolaridade

Em todos os países pesquisados pelo Banco Mundial, sem exceção, trabalhadores com maior qualificação tendem a ganhar mais que aqueles com menor grau de escolaridade. Os paises selecionados nos Gráficos 13 e 14 confirmam este resultado. Países em que a qualificação é um bem escasso na economia, como no caso da Tailândia, Indonésia, Brasil e Peru, apresentam remuneração proporcionalmente maior relativamente a países em que é mais comum encontrar trabalhadores mais qualificados, como Estados Unidos e Eslovênia.

Nos dois Gráficos pode-se verificar que na Indonésia, Peru e Tailândia, a qualificação afeta mais os salários das mulheres que dos homens. Isso não quer dizer que as mulheres ganham mais que os homens, mas que o retorno econômico decorrente de sua especialização, relativamente a uma trabalhadora sem escolaridade, é maior. 
Confirma-se, assim, o importante papel que podem desempenhar os investimentos em educação, a fim de redistribuir a renda nacional. É interessante observar que a desigualdade observada no Brasil decorre em grande medida de desigualdades salariais. Por sua vez, a crescente complexidade das relações de trabalho, criando uma hierarquia administrativa que aufere remunerações altíssimas a título de salário, em contraposição à grande maioria que tem rendimentos fixados nos patamares inferiores, é responsável pela substancial desigualdade salarial.

\subsection{2 - Os programas de renda mínima}

O Senado brasileiro aprovou, em dezembro de 1991, projeto de lei de autoria do Senador Eduardo Suplicy que institui o Programa de Garantia de Renda Mínima (PGRM). Até o final de 1996, a Câmara ainda não havia votado o projeto.

Essa proposta, que visa complementar a renda de pessoas que auferem baixos rendimentos ou mesmo nenhum, não é nenhuma novidade em termos mundiais. Aristóteles, em 300 a.C. (SUPLICY \& BUARQUE, 1996, p.5) já afirmara que a finalidade da política é a vida justa, e que para se alcançar esta condição é necessário, antes de mais nada, promover justiça distributiva.

A Bíblia também apresenta passagens em que 0 ideal de igualdade distributiva é exaltado. Outros autores, desde a Idade Média até nossos dias também manifestaram-se favoráveis a uma distribuição de recursos que fosse igualitária. Mais recentemente, em 1975, no governo Ford, os Estados Unidos transformaram em lei proposta do Senador Russel Long, que previa a criação do "Earned Income Tax Credit" (EITC), uma espécie de imposto de renda negativo. Em 1993, a administração Clinton expandiu o EITC, que passou a ser o programa de transferência de renda mais importante no país. 
Na Europa, muitos paises, entre os quais Reino Unido, Suécia e Bélgica, garantem atualmente "um benefício por criança até que ela complete a escola básica, como um direito à cidadania" (SUPLICY \& BUARQUE, 1996, p.8).

Como visto anteriormente, a redistribuição de renda para os que ganham menos é uma ação que beneficia o capitalismo, uma vez que provoca o aumento da produção total, do emprego e dos lucros, desde que haja capacidade ociosa na produção de todas as mercadorias. O programa de renda mínima é, portanto, oportuno sob vários aspectos.

\subsubsection{1 - As diferentes modalidades}

O projeto original do Senador Eduardo Suplicy previa que toda pessoa com 25 anos ou mais, com renda mensal inferior hoje a $\mathrm{R} \$ 240,00$, teria direito a uma complementação de renda equivalente a $30 \%$ da diferença entre aquele valor e sua renda. Exemplificando, um trabalhador que ganha $R \$ 120,00$ teria direito à complementação no valor de $\mathrm{R} \$ 36,00$. Caso haja disponibilidade de recursos e a experiência do programa recomende, poderia ser ampliado o benefício para $50 \%$ daquela diferença. Outro mecanismo previsto seria a implantação gradual: durante o primeiro ano, pessoas com 60 anos de idade ou mais teriam acesso ao PGRM; durante o segundo, os com 55 anos ou mais, e assim sucessivamente até que se chegasse, após oito anos, aos com idade de 25 anos ou mais.

Esse projeto do Senador Suplicy prevê o chamado benefício universal. Nenhuma outra condição estaria vinculada à concessão, a não ser idade acima de 25 anos e renda abaixo de R\$240,00. Há críticas quanto a esse modelo.

Uma delas é que haveria estímulo ao não trabalho. Quanto maior a diferença relativamente aos $\mathrm{R} \$ 240,00$, maior o valor do benefício. Isso significa que os que não auferem nenhuma renda receberiam o teto, $R \$ 72,00$. Outra crítica é que pessoas que não são pobres também seriam beneficiadas. 
Exemplificando, a mulher de um banqueiro, que não trabalhe, poderia entrar no programa, pois sua renda é zero. O alto custo do programa, em torno de $R \$ 21$ bilhões, seria outro complicador.

Já à época, chamou-se a atenção para o fato de que era muito grande o número de crianças na faixa de idade entre 7 e 14 anos que estava trabalhando em áreas rurais ou urbanas. Sabe-se que a mão-de-obra dessas crianças é utilizada em diferentes cultivos, como os do café, cana-de-açúcar e laranja, em minas de carvão ou nas ruas, vendendo doces e outros produtos e serviços. Esse problema ainda permanece, de forma que o IBGE divulgou que, em 1995, havia cerca de 3,5 milhões de crianças nessas condições.

Elas começam a trabalhar cedo porque há necessidade de colaborar no sustento da família, uma vez que seus pais não ganham o suficiente. Quando alcançam a idade adulta, é muito dificil conseguir emprego porque não têm qualificação - não houve chances de se dedicarem aos estudos.

Assim, uma forma de combater esse grave problema foi a idéia de vincular o programa de renda mínima à obrigatoriedade de educação. Mas como?

Alguns municípios importantes, como Campinas e Ribeirão Preto, além de outros menores e o Distrito Federal implantaram programas de renda minima com uma característica comum: ao invés do indivíduo, a família é que é beneficiária. Adicionalmente, deve ter filhos em idade escolar, entre 7 e 14 anos. $O$ benefício só é pago se as crianças não ultrapassarem determinada quantidade de faltas no mês.

Em Brasilia, o programa foi implantado pelo Governador Cristóvão Buarque em 1995, com o nome de Bolsa-Escola ou Bolsa-Educação. Ficou definido que têm direito a um salário mínimo mensal todas as famílias com renda menor que meio salário mínimo "per capita", sendo moradoras da capital federal há pelo menos 5 anos e com filhos de 7 a 14 anos de idade, desde que seus filhos frequentem pelo meros $90 \%$ das aulas na escola pública. Caso a 
criança falte à escola mais de dois dias por mês, o pagamento é interrompido Também se exige que, havendo trabalhador desempregado, ele se matricule no Sistema Nacional de Emprego (SINE), para provar que realmente procura emprego.

O programa é válido por um ano, mas as famílias podem renová-lo por períodos sucessivos de um ano desde que permaneçam as condições requeridas. Calcula-se que haja 20.000 famílias em condições de se habilitarem ao programa em Brasilia. Destes, 15.000 já participam, de forma que se espera atender todas as famílias habilitadas até meados de 1997.

Há indicadores que comprovam os resultados positivos do programa. Em 1996, 30.000 crianças são assistidas. Desde a sua implantação, a taxa de repetência, que era de $22 \%$, caiu para $7 \%$. A taxa de evasão escolar, que ficava entre $8 \%$ e $10 \%$ dos alunos que se matriculavam em escolas públicas, despencou para $0,2 \%$. Em 1995, 79,8\% das crianças matriculadas no programa obtiveram aprovação em seus respectivos anos letivos, contra uma taxa de cerca de $89 \%$ em 1994.

$\mathrm{Na}$ verdade, esses resultados são extraordinários, uma vez que conjugam duas grandes virtudes: diminuição das desigualdades de renda e priorização da educação. Conforme visto no item anterior, a maior qualificação permitirá a essas crianças lutar por melhores empregos no futuro, ainda mais se a formação escolar permanecer como um bem escasso na economia brasileira.

A implantação do programa de renda mínima em nivel nacional busca, justamente, superar essas dificuldades. Resta saber quais as possibilidades de sua efetivação. Além daquelas cidades citadas, muitas outras adotaram programas semelhantes, especialmente no interior de São Paulo, ou estão em vias de implementá-los. Infelizmente, os municípios mais pobres, que são os que mais carecem de tais medidas, são os que têm menores condições de 
implementá-los. Não há outra alternativa, em princípio, senão uma ação de responsabilidade do governo federal.

Recentemente o Congresso aprovou projeto de renda mínima do Senador José Roberto Arruda, contendo algumas modificações em relação à proposta do Senador Eduardo Suplicy.

Incorporando as experiências das cidades que implantaram programas de renda mínima, propõe uma complementação de renda para familias carentes com filhos em idade escolar, em cidades com menos de 50 mil habitantes. Seriam incluídos, dessa forma, 3.854 municípios brasileiros, o que corresponde a $90,1 \%$ do total. O total de familias assistidas chegaria a 4,9 milhões, com renda inferior a $R \$ 150,00$ por mês.

Para que o benefício em dinheiro, de $R \$ 50,00, R \$ 100,00$ ou $R \$ 150,00$ - conforme o número de filhos - fosse pago, a família teria de cumprir o requisito de manter as crianças na escola, com pequeno número de ausências no mês. A vantagem do projeto do Senador Arruda é o custo, no montante de $\mathrm{R} \$ 5,88$ bilhões ao ano, sensivelmente inferior ao da proposta do Senador Suplicy.

O Deputado Germano Rigotto, da Comissão de Finanças e Tributação da Câmara, emitiu parecer favorável à proposta do Senador Suplicy, mas esta deve seguir para votação com algumas modificações. O substitutivo do Deputado Rigotto, de julho de 1996, altera as condições para eleger os beneficiários do programa: além de possuir renda "per capita" mensal menor que $R \$ 240,00$, deve pertencer a uma família com renda mensal inferior a $R \$$ 720,00 . Os beneficiários com filhos entre 7 e 14 anos devem provar que os mesmos estão frequentando as aulas. A implementação do PGRM também sofre modificação: ao invés de se iniciar com os grupos etários de mais idade, começar-se-ia pelos estados mais pobres, em direção aos estados com maior renda "per capita". 
Finalmente, um dos programas de renda mínima estudados pelo Professor André Urani, pesquisador do Instituto de Pesquisa Econômica Aplicada - IPEA. Este seria dirigido a famílias que possuem renda "per capita" de até $R \$ 35,00$, com filhos em idade escolar, entre 7 e 14 anos. $O$ benefício mensal proposto é de um salário mínimo, atualmente fixado em $\mathbf{R} \$ \mathbf{1 1 2 , 0 0}$. Inserir-se-iam nestas condições cerca de 35 milhões de pessoas. O custo total do programa chegaria a $R \$ 7$ bilhões ao ano. Se se considerar como pobres ou miseráveis aquelas famílias com renda mensal "per capita" inferior a $\mathrm{R} \$ 35,00$ (esta seria a linha de pobreza interpolada), cerca de $24,5 \%$ da população ficaria abaixo dessa faixa. Após a implementação do programa, apenas $8 \%$ das pessoas estaria nessa condição.

Para analisar a factibilidade da implantação de tais programas, passa-se a analisar a questão do financiamento.

\subsubsection{2 - As alternativas de financiamento do PGRM}

É alto o custo da adoção de programas de renda mínima, o que leva à discussão de como financiá-lo. Certamente, um aumento de impostos poderia satisfazer esse acréscimo de gastos. O aumento da carga fiscal, entretanto, está no momento fora do que é possivel, dado que a carga sobre pessoas físicas e jurídicas já é alta para padrões internacionais. Aliás, o que se discute é que há necessidade de uma reforma tributária que desonere o setor produtivo, pois este problema é um dos responsáveis pela baixa competitividade das indústrias brasileiras. As pessoas físicas também manifestam-se pela redução da sua carga de tributação.

Se não é factivel satisfazer o aumento de custos com aumento dos impostos, há que se buscar outras alternativas, não esquecendo que um aumento do consumo da ordem de R\$ 7 bilhões teria algum impacto inflacionário, com certeza. 
Relativamente ao Orçamento Geral da União, esse valor representaria uma participação de apenas $2,2 \%$. Isso significa que um corte em todos itens da despesa do governo, da ordem de $2,2 \%$, possibilitaria o custeio do programa durante um ano. Esse tipo de medida seria o ideal - no global, o consumo final não sofreria pressão.

Outro caminho poderia ser a redução da renúncia fiscal. A Receita Federal estima em R\$ 20,8 bilhões, em 1996, os recursos que deixa de arrecadar em função, por exemplo, de incentivos regionais, como para a Zona Franca de Manaus (R\$ 2,5 bilhões), deduções do Imposto de Renda das pessoas físicas ( $R \$ 8,5$ bilhões) ou benefícios para microempresas ( $R \$ 2,6$ bilhões).

Um terceiro caminho para o governo seria tirar recursos de outros programas que estão sendo implementados. Pelo Orçamento, verifica-se que nenhum dos atuais programas tem um custo da magnitude do requerido pelo último programa de renda mínima apresentado, da ordem de $\mathrm{R} \$ 7$ bilhões. Mas se forem feitos cortes em vários programas, associados à exclusão de um ou outro, é possivel carrear os recursos necessários para o programa de renda mínima.

Mas a transferência de gastos de um programa atual para um programa de renda mínima não minimizaria os efeitos do PGRM sobre a desigualdade de renda? É claro que os programas que sofrerem redução de investimentos ou extinção trarão alguma perda social, mas as avaliações atuais mostram que, com algumas exceções, o retorno a tais investimentos é pequeno. Assim, uma realocação de recursos otimizaria as aplicações do governo federal.

O caminho mais factivel seria a combinação das três propostas, para tornar real a consecução de uma redistribuição de renda associada a investimentos em educação.

Na verdade, a questão é de priorização de gastos do governo. Em 1996, por exemplo, o Orçamento previu gastar R\$ 3,7 bilhões em operações militares, 
1,1 bilhão em equipamentos de informática e $R \$ 4,4$ bilhões com 0 ordenamento econômico-financeiro. Sabe-se que os custos do PROER (Programa de Estímulo à Reordenação do Sistema Financeiro) superaram em muito esta previsão, tendo consumido mais de $R \$ 15$ bilhões.

Assim, se o governo se convencer dos benefícios não apenas sociais, mas econômicos e também políticos que resultarão da adoção de um programa de renda mínima, terá argumentos para negociar o apoio do Congresso na aprovação de tal medida.

\section{3 - Possíveis impactos macroeconômicos decorrentes de uma redistribuição dos rendimentos}

Podem ser muitos os efeitos de uma redistribuição de renda em direção aos menos favorecidos. Tenta-se aqui discutir os mais importantes, orientandose pelo referencial teórico apresentado.

A primeira observação diz respeito ao instrumento escolhido para realizar tal redistribuição. Conforme o caminho a trilhar, podem variar a intensidade e a dispersão no tempo dos efeitos decorrentes. Primeiramente se discute os desdobramentos mais diretamente associados a cada uma das duas políticas. Depois de apresentados estes, fala-se dos que estão propriamente relacionados à redistribuição de renda.

\subsection{1 - Os principais efeitos associados à especificidade de cada política}

Relativamente aos investimentos em educação, a melhoria do ensino básico permitirá às crianças e jovens alcançar vôos mais altos em direção a uma maior graduação escolar. Embora seja necessário tornar o ensino superior 
público custeado pelos estudantes, a fim de gerar recursos suficientes para uma reforma qualitativa do ensino básico, a melhor preparação neste acabará estimulando a maior participação dos jovens no terceiro grau e na pósgraduação.

Esses estudantes, podendo contar com um ensino de qualidade, e também tendo à sua disposição escolas técnicas e de nivel superior voltadas para as necessidades do mercado de trabalho, tornar-se-ão, a longo prazo, profissionais qualificados. A maior qualificação do trabalhador, como as experiências em todo o mundo demonstram, resulta em maiores salários.

Com capital humano mais qualificado, serão maiores as condições do Brasil participar da competição imposta pela globalização dos mercados. A concorrência internacional tem mostrado que é possivel aos países adquirir tecnologia, entretanto aqueles que tem mais capital humano são os que conseguem um diferencial de qualidade em seus produtos e serviços. Cada vez mais, a diferença competitiva será dada pela qualificação das pessoas e não somente pelo potencial dos equipamentos e dos recursos naturais.

Quanto aos programas de renda mínima associados à educação, haveria forte estímulo à educação de amplo contingente populacional, a exemplo do que ocorre em Brasília. Como consequência, seria tirada do trabalho precoce a maioria das crianças que necessita hoje complementar a renda familiar. Sem a concorrência infantil, abrir-se-iam maiores oportunidades de emprego para os adultos, a taxas salariais maiores.

A complementação de renda prevista nos programas de renda mínima representaria um apoio decisivo à estruturação de famílias de condições econômicas desfavoráveis. A perspectiva de receber, todo mês, por exemplo, um salário mínimo desde que cumpridas as regras estabelecidas, serviria de estímulo ao progresso de famílias que têm carências materiais profundas. A existência do programa tornaria possíveis objetivos que, na sua ausência, dificilmente se materializariam. 
Finalmente, os possíveis efeitos enunciados em parágrafos anteriores, relativos à educação, valem, logicamente, para os programas de renda mínima a serem implementados na linha do que está em funcionamento em Brasília.

\subsection{2 - Os impactos macroeconômicos decorrentes das políticas adotadas, associados diretamente à redistribuição dos rendimentos}

\subsubsection{1 - Inflação}

Uma das maiores preocupações com a retomada de um crescimento econômico mais forte é a relativa ao comportamento da inflação. Teme-se que, mesmo após alguns anos de convivência com inflação baixa, pressões de demanda resultem em maiores preços, e aos poucos se retome o processo de reposição inflacionária associado à indexação.

Conforme o desenvolvimento do modelo oligopólico de Kalecki, a redistribuição dos rendimentos dos lucros para os salários provoca elevação de preços. Por sua vez, os salários são novamente reajustados, levando a novo aumento de preços. Esse processo, entretanto, não continua indefinidamente, uma vez que essas empresas têm como um dos principais instrumentos de competição a fixação de preços mais atrativos.

Por outro lado, viu-se no capítulo anterior que a inflação permaneceu alta por muito tempo no Brasil, tendo sido, na década de oitenta, um dos principais fatores que conduziu ao agravamento da concentração de renda. Desta forma, fica difícil aceitar o argumento kaleckiano de que a concorrência imperfeita termina por estancar o processo de aceleração inflacionária.

A favor do modelo, contudo, tem-se o contexto experimentado, em que a economia brasileira aperfeiçoou sobremaneira os instrumentos de perpetuação 
da inflação, o que é comprovado pela dificuldade que os vários planos tiveram para conter os aumentos de preços. Assim, numa economia sem tantos vícios inflacionários prevaleceria o argumento de Kalecki.

Felizmente, já são decorridos mais de dois anos em que a economia brasileira apresenta relativa estabilidade de preços. O Plano Real, conjugando algumas inovações à experiência das outras tentativas de estabilização, tem conseguido impedir a retomada do movimento ascendente de preços. É claro que ao longo dos meses há oscilações, mas a tendência presente em períodos maiores é de queda, até que se chegue à inflação anual de um dígito. Interessa aqui o fato de que a súbita queda da inflação no início do Real causou uma significativa redistribuição de renda em favor dos estratos de menor renda, o que é comprovado seja por dados oficiais, seja pelo comportamento da demanda nos meses que se seguiram à sua implantação.

Também teve destaque a evolução favorável da conjuntura econômica internacional, apesar dos efeitos da crise cambial mexicana $\left(1^{\circ}\right.$ semestre de 1995) - mas que assim mesmo serviu de alerta para o Brasil. A conjugação de fatores como esse, associada à condução da política econômica, que priorizou a estabilização de preços, contribuíram para a diminuição da desigualdade de renda, conforme mostra o Gráfico 14. 
Gráfico 14

Variação percentual do rendimento médio mensal das pessoas de 10 anos ou mais de idade, com rendimento - 1995/1993

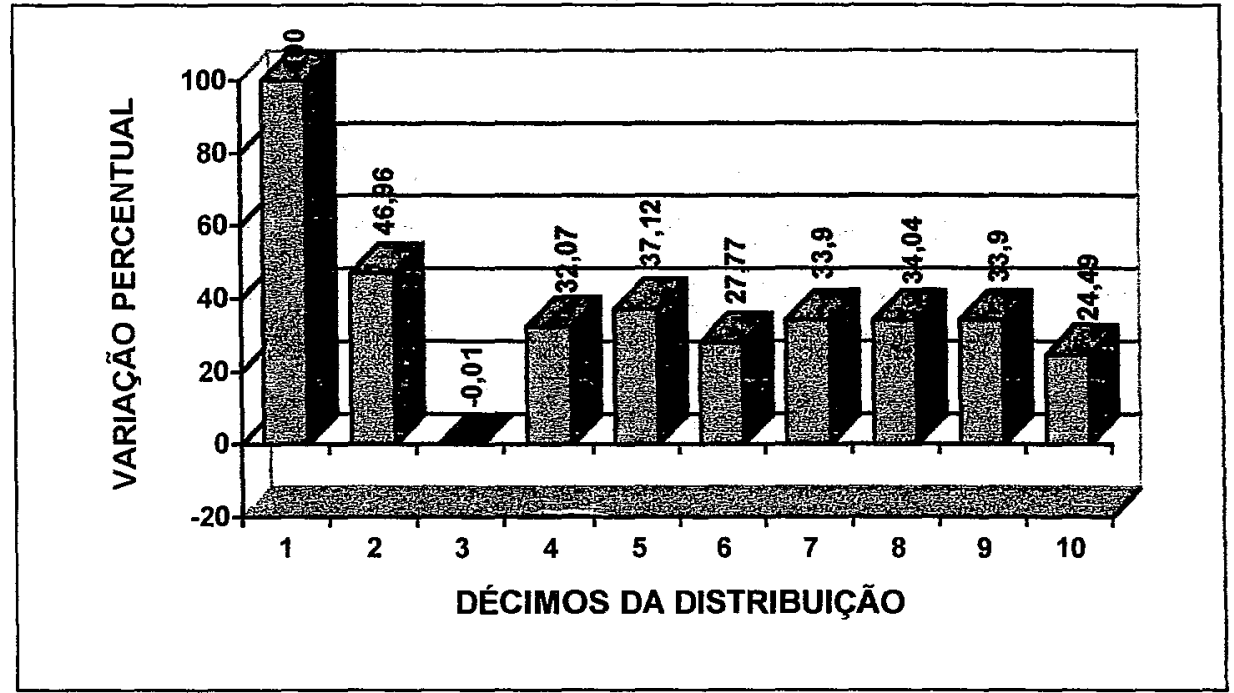

Fonte: PNAD (1995)

Sobressaem-se os $10 \%$ mais pobres, que tiveram sua renda incrementada em 100\% entre setembro de 1993 e setembro de 1995 . Entre os demais, todos tiveram sua renda real aumentada, à exceção do terceiro estrato, que apresentou variação praticamente nula. O segundo estrato foi o único, dentre esses, que superou a casa dos $40 \%$. Na outra ponta, os $10 \%$ mais ricos aumentaram sua renda média, mas num patamar inferior ao obtido pela maioria dos demais estratos.

Os $40 \%$ mais pobres tiveram um ganho de cerca de $29 \%$ com o Plano Real, enquanto os $10 \%$ mais ricos aumentaram seus rendimentos em $24,5 \%$.

O próprio Kalecki $(1977$, p.100) contempla a estabilização de preços como um dos instrumentos que afetam a distribuição da renda nacional, de forma que não restam dúvidas acerca de seu papel redistributivo. Cabe agora questionar, num primeiro momento, a intensidade do impacto causado no comportamento da inflação, e a seguir, em outras variáveis macroeconômicas relevantes. 
O acréscimo de renda das pessoas de 10 anos ou mais de idade, com rendimento, entre setembro de 1993 e setembro de 1995 foi de cerca de R\$ 6 bilhões. Para se chegar a esse valor, utilizou-se a variação da renda média de cada estrato e multiplicou-se por $1 / 10$ do total daquela população, com rendimento (dados da PNAD 1995). O resultado é a soma das parcelas.

Considerando, entretanto, que o PIB variou cerca de $7 \%$ no mesmo período, a diferença apresentada da variação da renda média entre as PNADs 1993 e 1995 mostra-se exagerada. Aqui se volta à questão de que a PNAD reflete essencialmente situações de determinados meses, o que pode ter levado a uma superestimação do acréscimo de renda. Assim, uma variação próxima a $R \$ 2$ bilhões entre os dois anos seria mais realista.

De qualquer forma, supondo que permaneceu constante o investimento no periodo, um acréscimo de renda de tal magnitude deve ter causado pressão na consumo, o que teria contribuído para elevar a inflação, especialmente entre julho de1994 e junho de 1995, que foram os meses mais próximos dos efeitos benéficos da estabilização de preços.

Ora, conforme se pode ver na Tabela 23, a tendência da inflação não foi ascendente. Como explicar, na visão monetarista, que um aumento dos recursos em moeda não contribuiu para o aumento da inflação?

\section{Tabela 23}

Variação Mensal do IPC-Fipe e do INPC

Índice $07 / 94$ 08/94 09/94 10/94 11/94 12/94 01/95 02/95 03/95 04/95 05/95 06/95

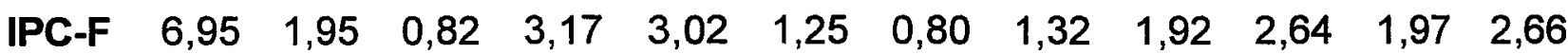

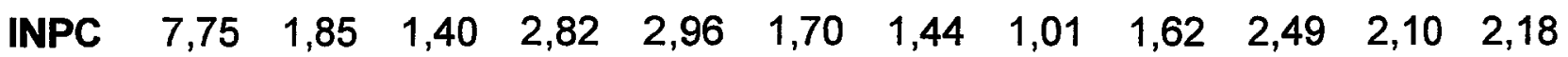

Fonte: FIPE e IBGE

Sem dúvida que houve pressões por aumento de preços, mas o Governo, já antevendo esse cenário, reduziu as tarifas de importação de uma 
ampla gama de bens de consumo, ampliando a concorrência e impedindo abusos de preços. O aumento do coeficiente de importações gerou, mais à frente, outros problemas ligados ao déficit comercial, mas foi eficiente para conter uma alta inflacionária.

Aqueles que argumentam, portanto, que a implantação de uma política redistributiva da renda não é recomendável por causa dos efeitos inflacionários que ocasiona, têm na experiência recente exemplo que prova o contrário. Caso se pense na proposta de renda mínima associada à educação, que garanta renda adicional às famílias que ganham até $R \$ 35,00$ de renda familiar per capita, o custo do programa, que viria a pressionar a demanda interna, seria da ordem de R\$ 7 bilhões, conforme exposto. Caso esses recursos sejam criados antecipadamente, conforme discutido às pp.110-111, e/ou se o projeto for implantado de maneira escalonada, por estados da federação ou por grupos de idade, não causaria um forte impacto inflacionário.

Quanto às outras propostas apresentadas no item anterior, também não se visualizam maiores complicações relacionadas à inflação. A reforma agrária, conforme discutida, não fará sentido se não levar em conta a diversidade da realidade rural hoje presente. Como são diversas as políticas a serem implantadas para configurar uma reforma abrangente, poder-se-ia trilhar o mesmo caminho sugerido para os programas de renda mínima: implantação gradual.

Os investimentos em educação devem, da mesma forma, acontecer ao longo dos anos, e surtirão efeito apenas no longo prazo, de forma que a inflação não se configura em elemento inibidor das políticas propostas. 


\subsubsection{2 - Consumo e Investimento}

$\mathrm{Na}$ teoria da demanda efetiva, seja na construção de Kalecki ou de Keynes, a variável fundamental da dinâmica capitalista é o investimento.

Isso não quer dizer, conforme visto às pp.113/114, que não haja relação importante entre o consumo e o investimento. $O$ multiplicador de investimento de Keynes, que tem na teoria de Kalecki um fator bastante similar, é o maior exemplo. Quanto maior a propensão a consumir, maior o multiplicador.

Dessa forma, estuda-se o provável comportamento do consumo em decorrência de uma redistribuição dos rendimentos, não porque seja através de sua influência direta que o crescimento sustentado deverá ser retomado, mas porque o aumento da propensão a consumir deverá, no longo prazo, estimular os investimentos. Mais à frente se qualifica melhor os condicionantes destes últimos, que são os determinantes do ritmo de acumulação.

Não resta dúvida de que uma renda adicional nas mãos dos agentes econômicos mais carentes levará a um maior consumo de bens, seja de alimentação num primeiro momento, seja de produtos populares após a estabilização num patamar de consumo mais elevado.

O modelo de Kalecki mostrou que o setor de bens de consumo dos trabalhadores é o que sofre os maiores impactos, com aumento da produção e do emprego. Mais especificamente, quais os segmentos de produção dentro desse setor que terão sua demanda aumentada?

Para fazer projeções é necessário estabelecer o programa através do qual deverá ocorrer a redistribuição dos rendimentos. Uma vez que o programa de renda mínima é o que permite calcular com maior clareza os recursos envolvidos, este é o que será empregado para se tentar antever os possiveis impactos.

Opta-se pelo programa de renda mínima associado à educação, que beneficiaria famílias com crianças em idade escolar de renda familiar per capita 
de até $\mathrm{R} \$ 35,00$. Em média, a renda familiar seria, portanto de cerca de $\mathrm{R} \$$ 140,00. São famílias com muitas carências materiais. Vale lembrar que em 1986, por ocasião do Plano Cruzado, quando se verificou uma significativa e efêmera redistribuição dos rendimentos, aumentou em $350 \%$ a demanda de camas. Muitos dos responsáveis por essa expansão do consumo simplesmente dormiam no chão.

Com o Plano Real podemos, mais uma vez, verificar o comportamento de consumo dos estratos de menor renda, que foram os mais beneficiados com o fim do "imposto inflacionário". Os jornais publicaram matérias, especialmente em 1995, destacando um movimento de grandes proporções relacionado às classes de baixa renda: esse "grupo" social, com renda mensal familiar entre 3 e 10 salários mínimos, foi às compras de eletroeletrônicos, esvaziando as prateleiras das lojas localizadas nas periferias dos grandes centros urbanos.

Não apenas o contingente de brasileiros situado naquela faixa de renda, que engloba cerca de $35 \%$ da população brasileira, aumentou sobremaneira seu consumo. As classes de renda situadas nos estratos inferiores também ampliaram a demanda de produtos básicos, principalmente alimentos. Com o detalhe de que bens fora da chamada cesta básica de consumo, como iogurtes, foram os que mais tiveram seu consumo ampliado entre 1994 e 1995.

O Gráfico 15 e a Tabela 24 mostram o comportamento do consumo de alguns bens duráveis entre os anos 1993 e 1995, através da existência desses bens nos domicílios. 


\section{Gráfico 15}

\section{Existência de Alguns Bens Duráveis nos Domicílios - Brasil}

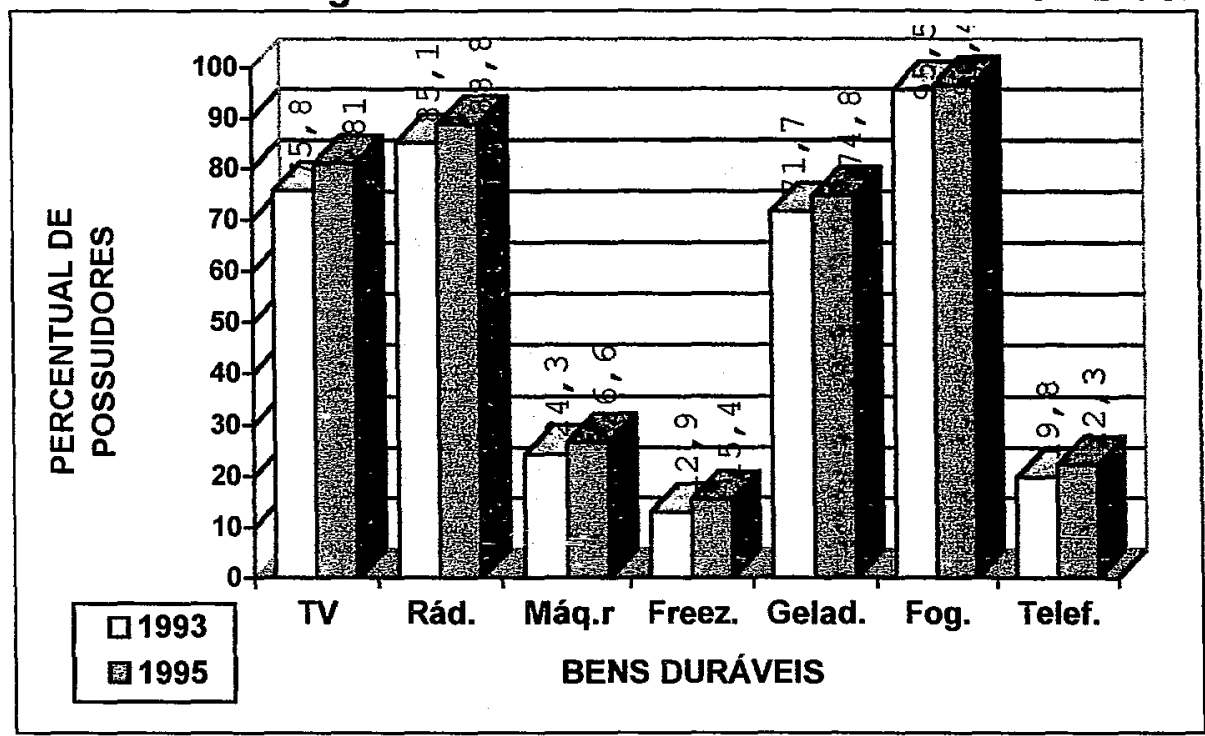

Fonte: PNAD (1993 e 1995)

Tabela 24

Quantidade de bens duráveis nos domicilios - Brasil

\begin{tabular}{lcc}
\hline Domicílios/ Bens Duráveis & 1993 & 1995 \\
\hline Total de Domicílios & $36.957 .963(100 \%)$ & $38.969 .714(100 \%)$ \\
Televisão & $27.998 .535(75,8 \%)$ & $31.575 .938(81,0 \%)$ \\
Rádio & $31.442 .592(85,1 \%)$ & $34.606 .922(88,8 \%)$ \\
Máquina de Lavar Roupa & $8.963 .065(24,3 \%)$ & $10.371 .276(26,6 \%)$ \\
Freezer & $4.782 .783(12,9 \%)$ & $5.994 .169(15,4 \%)$ \\
Geladeira & $26.499 .744(71,7 \%)$ & $29.149 .375(74,8 \%)$ \\
Fogão & $35.278 .177(95,5 \%)$ & $37.554 .280(96,4 \%)$ \\
Telefone & $7.300 .830(19,8 \%)$ & $8.682 .749(22,3 \%)$ \\
\hline
\end{tabular}

Fonte: PNAD (1993 e 1995)

Enquanto o total de domicílios cresceu cerca de $5,4 \%$ entre os dois anos, a quantidade de freezers cresceu $25,3 \%$, a de telefones $18,9 \%$, a de 
máquinas de lavar roupa $15,7 \%$, a de televisores $12,7 \%$, a de rádios $10,1 \%$, a de geladeiras $10 \%$ e a de fogões $6,4 \%$. Esses números comprovam a melhoria no nível de vida da população brasileira após o Real. Mas será que, em se promovendo nova redistribuição dos rendimentos, serão mais demandados, em ordem de preferência, os mesmos bens?

Em primeiro lugar, os alimentos mais diferenciados, como os laticínios, devem repetir seu desempenho de vendas, uma vez que a população que já consome produtos básicos teria um acréscimo de renda que, se não substancial, seria suficiente para a ampliação qualitativa de seu consumo.

Como segundo efeito, a procura por bens duráveis de consumo populares também seria estimulada. As pesquisas de mercado contemplam uma gama maior de bens, incluindo bens relacionados ao lazer. 
Tabela 25

Produtos mais importantes (em \%)

\begin{tabular}{llll}
\hline PRODUTOS & CLASSES A/B & CLASSE C & CLASSE D \\
\hline Fogäo & 96 & 95 & 98 \\
Geladeira & 98 & 94 & 94 \\
TV & 80 & 84 & 83 \\
Máquina de lavar roupa & 84 & 63 & 73 \\
Liquidificador & 76 & 74 & 70 \\
Rádio & 60 & 62 & 63 \\
Telefone & 77 & 49 & 46 \\
Aparelho de som & 43 & 48 & 63 \\
Caderneta de poupança & 49 & 45 & 63 \\
Carro & 67 & 46 & 32 \\
Freezer & 45 & 28 & 24 \\
Batedeira & 33 & 31 & 32 \\
Cartão de crédito & 32 & 24 & 35 \\
Microondas & 27 & 27 & 21 \\
Computador & 34 & 16 & 14 \\
Viajar & 21 & 17 & 22 \\
Videocassete & 20 & 24 & 20 \\
Aspirador de pó & 35 & 12 & 10 \\
Máquina de secar roupa & 13 & 15 & 29 \\
Telefone celular & 14 & 9 & 11 \\
Telefone sem fio & 12 & 14 & 8 \\
Cafeteira elétrica & 8 & 10 & 13 \\
Secretária eletrônica & 12 & 6 & 8 \\
\hline Fonte:Folha die Så Pauto & & \\
\hline
\end{tabular}

Fonte: Folha de São Paulo, edição de 27.11.96 
A Tabela 25 apresenta a pesquisa da Agência ALMAP, dividindo as classes sociais pelo critério ABA, da Associação Brasileira de Anunciantes ${ }^{3}$.

Para os bens contemplados na PNAD 1995, conjugando a porcentagem de domicílios possuidores com a importância conferida pelas classes $C$ e $D$ na pesquisa da ALMAP, os seguintes bens seriam os mais demandados em decorrência do aumento de renda para aquelas classes, em ordem de prioridade:

- Máquina de lavar roupa

- Geladeira

- Televisão

- Fogão

- Rádio

- Telefone

- Freezer

3 As pessoas são classificadas de acordo com os bens que possuem em casa e o grau de escolaridade. A cada item corresponde uma pontuação, conforme tabela abaixo. A soma dos pontos dá a classificação do entrevistado.

\begin{tabular}{|c|c|c|c|c|c|}
\hline & & & ade qu & & \\
\hline BENS & Zero & Um & Dois & Três & Quatro \\
\hline TV & 0 & 2 & 4 & 6 & 8 \\
\hline Rádio & 0 & 1 & 2 & 3 & 4 \\
\hline Automóvel & 0 & 4 & 8 & 12 & 16 \\
\hline Empregada fixa mensal & 0 & 6 & 12 & 18 & 24 \\
\hline Aspirador de pó & 0 & 5 & 5 & 5 & 5 \\
\hline Máquina de lavar roupa & 0 & 2 & 2 & 2 & 2 \\
\hline Banheiros & 0 & 2 & 4 & 6 & 8 \\
\hline ESCOLARIDADE & & & & \multicolumn{2}{|c|}{ Pontos } \\
\hline $\begin{array}{l}\text { Analfabeto ou até } 4^{\mathrm{a}} \text { série do } 1^{\circ} \text { grau } \\
\text { Da } 4^{\mathrm{a}} \text { série à } 7^{\mathrm{a}} \text { série do } 1^{\circ} \text { grau } \\
1^{\circ} \text { grau completo ou } 2^{\circ} \text { grau incompleto } \\
2^{\circ} \text { grau completo ou superior incompleto } \\
\text { Superior completo }\end{array}$ & & & & \multicolumn{2}{|c|}{$\begin{array}{c}0 \\
1 \\
3 \\
5 \\
10 \\
\end{array}$} \\
\hline CLASSIFICAÇÃO & & & & \multicolumn{2}{|c|}{ Classe Social } \\
\hline $\begin{array}{l}35 \text { pontos ou mais } \\
\text { De } 21 \text { a } 34 \text { pontos } \\
\text { De } 10 \text { a } 20 \text { pontos } \\
\text { De } 5 \text { a } 9 \text { pontos } \\
\text { Até } 4 \text { pontos }\end{array}$ & & & & \multicolumn{2}{|c|}{$\begin{array}{l}\text { A } \\
\text { B } \\
\text { C } \\
\text { D } \\
\text { E }\end{array}$} \\
\hline
\end{tabular}

Fonte: Folha de São Paulo, edição de 27.11.96 
Outros bens presentes na pesquisa de preferência também seriam mais demandados, especialmente liquidificadores e aparelhos de som. Há que se notar que o consumidor de baixa renda, aquele na faixa de 3 a 10 salários mínimos, tem modificado seu comportamento em relação ao consumo, aproximando-o bastante de práticas anteriormente típicas da classe média, que corresponderiam à classe $\mathrm{B}$ da pesquisa. Da mesma forma, os consumidores dos estratos inferiores, especialmente a classe $D$, também têm aproximado seu comportamento ao da classe imediatamente superior.

Isso significa que os chamados consumidores emergentes têm se tornado mais exigentes, em especial no que se refere à qualidade dos produtos e serviços oferecidos. O atendimento também é outro item levado em consideração na hora de comprar. Daí se depreende que as preferências da classe $\mathrm{C}$, e algumas vezes até mesmo da $\mathrm{B}$, devem ser levadas em consideração para avaliar possíveis movimentos da demanda em resposta a uma redistribuição dos rendimentos.

Finalmente, deve-se atentar para o comportamento do investimento, variável fundamental dentro da dinâmica capitalista.

Interessa aqui tentar antever seus desdobramentos em função dos ganhos obtidos pelos estratos mais pobres da distribuição. Uma vez que se tenha implementado, por exemplo, o programa de renda mínima citado, alguns empresários poderiam manifestar-se contra a medida, por considerarem que o gasto do governo poderia ser melhor empregado se direcionado a investimentos no setor produtor de máquinas e equipamentos nacionais. $E$ certo que sempre haverá quem se contraponha à medida, mas cabe atentar para o efeito produzido na classe empresarial como um todo.

Como demonstra o modelo de Kalecki, não há motivo aparente que leve a um declínio do investimento. A redistribuição de rendimentos provoca, inicialmente, um aumento da produção no departamento de bens de consumo para os trabalhadores, gerando um aumento do emprego nesse setor e depois 
um aumento dos lucros totais. A pré-condição é que exista capacidade ociosa em todos os setores da economia. O gráfico 16 mostra o comportamento da capacidade ociosa e do nível de atividade num período que cobre, na sua maior parte, o período pós-Real até agosto/1995.

\section{Gráfico 16}

\section{Nivel de Atividade* e Utilização da Capacidade na Indústria de}

\section{Transformação 4}

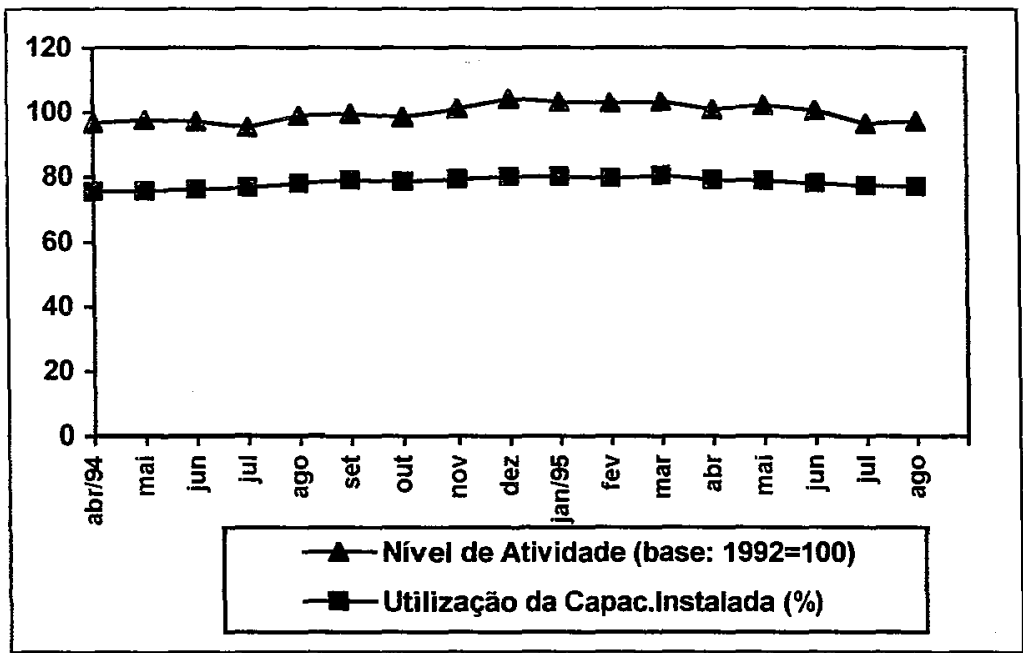

Fonte: CNI (1996) - indices dessazonalizados

* Definido com base nas horas trabalhadas

Vê-se que a estabilização relativa de preços provocou incentivo ao aumento do nível de atividade, que cresceu de julho a dezembro de 1994. Após esse mês, o movimento é de queda suave, reforçada apenas após maio de 1995, depois que foram tomadas medidas de contenção da demanda em resposta à crise mexicana que se manifestava.

A utilização da capacidade ociosa mostrou variação semelhante, mantendo-se em torno de $80 \%$ na maioria dos meses. Isso significa que a

\footnotetext{
4 Trata-se de um indicador nacional, contemplando os seguintes estados: Amazonas, Ceará, Pernambuco, Bahia, Espírito Santo, Rio de Janeiro, Minas Gerais, São Paulo, Paraná, Santa Catarina, Rio Grande do Sul e Goiás. Em cada estado a amostra cobre pelo menos $80 \%$ do valor da produção da indústria, nos mais diversos ramos.
} 
economia dominada por grandes empresas, caracterizada pela indústria nacional, usa a estratégia de manter ociosa, mesmo em tempos de maior pressão da demanda, parte de sua capacidade produtiva. Outro fator que contribuiu para que se mantivesse praticamente estável o grau de utilização da capacidade foi a abertura às importações, responsável por satisfazer parte do aumento de demanda quando este se manifestou.

Uma vez que, em crescendo, a produção da economia comece a se afastar do nivel considerado seguro de utilização da capacidade produtiva, ou ocorre pressão para reajuste de preços ou decide-se pelo aumento da capacidade de produção. Em outras palavras, por novo investimento.

Ora, sabe-se que o investimento é afetado por muitos fatores, sendo os mais importantes, na teoria de KALECKI (1985 e 1977, p. 113), os relacionados à acumulação interna de capital e à generalizada concorrência entre as empresas, que por sua vez induz à aceleração das inovações tecnológicas. $\mathrm{Na}$ obra de KEYNES (1985, pp.109-121) têm importante papel, no comportamento do investimento, o estado das expectativas a longo prazo e a taxa de juros, entre outros fatores. Para Kalecki, a taxa de juros relevante é a de longo prazo, que está muito pouco sujeita a flutuações, deixando, portanto, de exercer forte influência sobre o investimento.

As expectativas empresariais têm se mostrado favoráveis à expansão da economia brasileira, especialmente pelo interesse que têm demonstrado empresas estrangeiras em investir no mercado nacional. Confia-se, portanto, no processo de estabilização da economia, ao mesmo tempo que desponta o mercado brasileiro como um dos mais promissores do mundo.

Até mesmo, portanto, agentes econômicos estrangeiros esperam pelo fortalecimento do mercado interno no Brasil, pois sabem que quando diminuir ainda mais o grau de concentração da renda ocorrerá um aumento da propensão a consumir. Como visto, este aumento só não estimula o 
investimento em um contexto de plena utilização dos recursos, que não é o caso da economia brasileira atual.

Entretanto, ainda há muitos ajustes a serem feitos para que ocorra a retomada do crescimento de maneira sustentada. Além da queda dos juros, há que se aprovar reformas importantes como a administrativa, a tributária e a previdenciária; consolidar investimentos em infra-estrutura; abandonar completamente os mecanismos de indexação de preços; por fim, aumentar o coeficiente de exportações, para evitar grandes déficits na balança comercial. Certamente há outras pré-condições, mas acredita-se serem estas as mais importantes. As necessidades sociais, porém, não podem ser esquecidas.

Dessa forma, as políticas de redistribuição da renda podem contribuir muito para permitir a retomada do crescimento. Mas sabe-se que o contexto macroeconômico em que se inserir será determinante para dizer se esse crescimento será passageiro ou sustentado. A forma como se comportou a economia em decorrência da redistribuição de renda provocada pela estabilização de preços deu sinais de que há potencial de grande crescimento. A economia, entretanto, não estava preparada para dar esse salto. Por essa razão, conteve-se o nível de atividade, conteve-se o crescimento econômico.

Nesse sentido, a adoção de um programa redistributivo da renda abrangente, tal como a proposta de renda mínima associada à educação, provocará maiores transformações e efeitos mais duradouros se for implementada em contexto mais favorável, vale dizer se forem satisfeitas aquelas condições colocadas nos parágrafos anteriores.

Por sua vez, a dinâmica capitalista se encarregará de irradiar por toda a economia os benefícios da diminuição da desigualdade, podendo gerar um crescimento econômico que se sustente ao longo dos anos, condizente com uma inflação baixa e com o desenvolvimento do País na direção de uma participação destacada no cenário mundial. 


\section{5 - CONCLUSÃO}

A presença de desigualdade de renda, levando a desigualdades econômicas e sociais, faz parte da história do homem em muitas das organizações sociais já experimentadas. No capitalismo, a própria lógica da acumulação leva à polarização entre uma classe pequena que detém a propriedade do capital e um contingente maior daqueles que dispõem apenas de sua força de trabalho para auferir rendimentos. Nas décadas iniciais seguintes à Revolução Industrial chegou-se a um brutal grau de exploração da mão-de-obra, suscitando protestos contra aquela forma de produção que se encontrava em expansão.

Hoje, dois séculos após a consolidação do sistema capitalista por todo o globo, tornaram-se muito mais complexas as relações de produção. Cada vez mais o capital se despersonifica, destacando-se figuras como as do gerente ou do administrador no lugar do empreendedor capitalista. Algumas ocupações assalariadas auferem rendimentos que mais parecem ter a ver com os lucros.

Este trabalho revelou um processo de consolidação do capitalismo no Brasil muito mais rápido, relativamente às nações que passaram pela substituição do modo de produção em períodos anteriores. Por ter-se efetivado com relativo atraso e em ritmo mais intenso, os resultados aqui não foram uma repetição do ocorrido nas nações adiantadas. Particularmente, o aumento no grau de concentração da renda foi muito maior que o experimentado nas nações desenvolvidas, e mesmo em relação às demais economias em desenvolvimento ou emergentes. Não obstante a excepcional expansão 
do produto e da renda verificados nos anos de crescimento acelerado, foram limitados os resultados quanto à diminuição da pobreza e ao progresso social, dado seu caráter concentrador. Embora se tenha chegado ao maior grau de desigualdade de renda do planeta (hoje os dados revelam que o Brasil é o segundo neste ranking), a participação da remuneração do trabalho na renda não é tão baixa quanto tem sido divulgado recentemente. Particularmente, a participação dos salários na renda não é da ordem de $30 \%$, ou mesmo $38 \%$, mas pode-se falar que está entre $45 \%$ e $50 \%$, o que é ainda é pouco quando se compara com dados de paises desenvolvidos. Para um país emergente, entretanto, esta participação é mais compatível, mas ainda se pode melhorar muito com o fim de aumentá-la.

Destaque especial é atribuído à questão da informalidade presente no mercado de trabalho brasileiro. Apresenta hoje o Brasil um mercado de trabalho com alto índice de informalização das atividades, o que em boa medida contribui para gerar empregos de baixas qualidade e remuneração. Uma retomada do crescimento, ao intensificar o nível de atividade e aumentar a renda, levará ao fortalecimento da posição dos empreendimentos informais, os quais se encontram operando, em sua maioria, na economia submersa e em condições precárias. Nesse caso, a experiência mostra que poderá diminuir sensivelmente o grau de informalização e de ilegalidade, pois é intenção do empreendedor informal a participação no mercado em bases legais, e se possivel, ampliar sua "quota" produtiva.

$\mathrm{Na}$ análise da distribuição de renda pessoal, tem-se dois momentos mais importantes. O primeiro se relaciona ao desenvolvimento do mercado interno no Brasil. Gestado sob o impulso da economia cafeeira, esse mercado foi um resultado quase "colateral" da política de valorização do café. Ao se desvalorizar a moeda brasileira, as exportações brasileiras geraram mais divisas. Por outro lado, as importações encareceram, e à época responderam por significativa parcela do consumo e investimento nacionais. Dessa forma, 
estimulou-se a produção doméstica, e revelou-se o potencial do mercado interno.

As políticas desenvolvimentistas implementadas nas décadas seguintes, até 1970 , entretanto, tiveram por resultado ampliar a desigualdade de renda. É verdade que continuou a se fortalecer o mercado interno, mas tendo em vista o crescimento experimentado, poderia hoje ser $\circ$ Brasil um dos grandes mercados consumidores do mundo.

O segundo momento importante refere-se ao único período entre $1960 \mathrm{e}$ 1990, à exceção do Plano Cruzado, em 1986, que mostrou ter havido diminuição no grau de concentração da renda. Foi nos anos finais da década de 1970, quando o regime militar já mostrava sinais de desgaste e começou a emergir o movimento do operariado paulista. O governo, diante de tal quadro, foi levado a alterar a política salarial, privilegiando os reajustes dos que menos ganhavam, o que resultou em uma efetiva redistribuição dos rendimentos. $A$ exemplo do Plano Cruzado, essa redistribuição foi efêmera, pois as dificuldades externas levaram as autoridades a rever a lei salarial, provocando perdas para todas as faixas de rendimentos do trabalho. A aceleração inflacionária foi outro fator que minou os ganhos anteriores.

De qualquer forma, a pressão por maiores salários conseguiu resultados efetivos no Brasil. Hoje, entretanto, não se vislumbra um processo redistributivo da renda que seja baseado em maior pressão sindical. As relações trabalhistas estão em plena mutação e há urgência para que o movimento sindical se adapte às transformações que vêm ocorrendo. Seja como for, não se vislumbra nem no médio prazo uma situação como a dos anos 1978 e 1979 no Brasil.

Ao se discutir possiveis efeitos macroeconômicos decorrentes de alterações na distribuição de renda, procurou-se mostrar propostas redistributivistas que seriam, hoje, mais factíveis. Mas também observa-se que o ambiente político condiciona o crescimento econômico. O atual estágio da distribuição de renda, por sua vez, é variável de suma importância para 
determinar a configuração e as decisões políticas. Não é por outro motivo que o atual governo tem dado destaque ao resultado de diminuição do grau de desigualdade da renda após a implantação do plano de estabilização. A agenda para 1997 prevê aumento dos gastos sociais, pois o governo, pretendendo dar continuidade à política econômica, até mesmo anuncia o gasto de $R \$ 1$ bilhão em programa de renda mínima.

O resultado mais importante deste estudo refere-se, entretanto, aos impactos macroeconômicos decorrentes de uma redistribuição dos rendimentos. O modelo de Kalecki, baseado em oligopólios, e apropriado ao atual estágio de desenvolvimento da economia brasileira, mostra claramente que a redistribuição dos rendimentos em favor dos que menos auferem tem por resultados o aumento do emprego, da produção e dos lucros. Algum impacto inflacionário ocorre, mas não chega a ser um processo que se realimente continuamente.

O Plano Real provocou, efetivamente, redistribuição dos rendimentos, por seus impactos positivos sobre a inflação, o consumo e o investimento. Embora ainda não se tenha alcançado as condições ideais para o estabelecimento de um crescimento econômico sustentado, foi possível ao governo monitorar o grande crescimento da demanda agregada. Isto, por sua vez, sugere que a adoção de um amplo programa de redistribuição da renda nos próximos anos poderá suceder e ser acompanhado por uma série de medidas que visam consolidar a estabilização da economia brasileira. Aí sim será possível alcançar um crescimento acelerado e sustentado.

Foi persistente o quadro de manutenção de um alto grau de desigualdade em nosso país nas últimas décadas. Uma reversão deste processo através de medidas que venham a aumentar o poder de compra das classes menos favorecidas interessa não apenas a estas, mas inclusive à classe capitalista e ao funcionamento da economia de mercado no Brasil. 


\section{REFERÊNCIAS BIBLIOGRÁFICAS}

ALESINA, A. \& PEROTTI, R., The Political Economy of Growth: a Critical Survey of the Recent Literature, in The World Bank Economic Review, Vol.8, nr.3: 351-371, 1994.

AMADEO, E.; CAMARGO, J.M.; GONZAGA, G.; BARROS, R.; MENDONÇA, R., A Natureza e o Funcionamento do Mercado de Trabalho Brasileiro Desde 1980, em Texto Para Discussão nr. 353, IPEA, outubro de 1994.

BANCO MUNDIAL - O Trabalhador e o Processo de Integração Mundial, em Relatório do Banco Mundial. Washington D.C., 1995.

BANCO MUNDIAL - From Plan to Market, em World Development Report, Washington D.C., 1996.

BARROS, R. P. de \& MENDONÇA, R. S. P. de , A Evolução do Bem-Estar e da Desigualdade no Brasil desde 1960, em Desenvolvimento Econômico, Investimento, Mercado de Trabalho e Distribuição de Renda, Seminário BNDES, 1993, pp.13 a 28.

BOLETIM DIEESE - Anuário dos Trabalhadores - Brasil tem Destaque Negativo na América Latina, n.153, Ano XII, Dezembro de 1993.

BONELLI, R. \& SEDLACEK, G .L., Distribuição de Renda: Evolução no Último Quarto de Século, em Mercado de Trabalho e Distribuição de Renda: uma Coletânea. Rio de Janeiro: IPEA/INPES, 1989. 
BONELLI, R. \& RAMOS, L.R.A., Distribuição de Renda no Brasil: Avaliação das Tendências de Longo Prazo e Mudanças na Desigualdade desde Meados dos Anos 70, em Revista de Economia Política, V.13, n.2, abril/junho/1993.

CACCIAMALI, M. C., Emprego no Brasil Durante a Primeira Metade da Década de 80, em Mercado de Trabalho e Distribuição de Renda: uma Coletânea. Rio de Janeiro: IPEA/INPES, 1989a.

CACCIAMALI, M.C., Informalização Recente do Mercado de Trabalho Brasileiro, em Literatura Econômica, v.11, n.3, outubro/1989b.

CAMARGO, J.M., Informalização e Renda no Mercado de Trabalho, em Mercado de Trabalho e Distribuição de Renda: uma Coletânea. Rio de Janeiro, IPEAIINPES, 1989.

CARDOSO, E., Cyclical Variations of Earnings inequality in Brazil, em Revista ta de Economia Política, Vol.13, n.4, outubro/dezembro/1993.

CASTRO, A. Barros de, O Capitalismo Ainda é Aquele. Rio de Janeiro: ForenseUniversitária, 1979.

CASTRO, A.B. de \& SOUZA, F.E.P. de. A Economia Brasileira em Marcha Forçada. Rio de Janeiro: Paz e Terra, 1985.

CHAHAD, J.P. \& LUQUE, C.A., Políticas Econômicas, Emprego e Distribuição ção de Renda na América Latina. São Paulo: IPE/USP, 1984. 
CNI - Confederação Nacional da Indústria, Indicadores Industriais CNI, Novembro de 1996.

ESTATÍSTICAS HISTÓRICAS DO BRASIL - Séries Econômicas, Demográficas e Sociais de 1550 a 1988. Rio de Janeiro: IBGE, 1990.

FISHLOW, A., A Distribuição de Renda no Brasil, em A Controvérsia sobre Distribuição de Renda e Desenvolvimento. Rio de Janeiro: Zahar Editores, 1975.

FURTADO, Celso, Um Projeto para o Brasil. Rio de Janeiro: Saga, 1969 ( $5^{\mathrm{a}}$ edição).

GÓES, M.C., Nota Sobre a Participação dos Salários na Renda, em Texto para Discussão - 1a.versão, IBGE, maio de 1992.

HOFFMANN, R. \& KAGEYAMA, Angela A., Distribuição de Renda no Brasil, entre Familias e entre Pessoas, em 1970 e 1980, em Estudos Econômicos, Vol. 16, n.1, 1986.

HOFFMANN, R., Evolução da Distribuição da Renda no Brasil, entre Pessoas e entre Famílias, 1979/86, em Mercado de Trabalho e Distribuição de Renda: uma Coletânea. Rio de Janeiro: IPEA/INPES, 1989.

HOFFMANN, R., Estatística para Economistas. São Paulo: Livraria Pioneira Editora, 1991 ( $2^{\mathrm{a}}$ edição). 
HOFFMANN, R., Desigualdade e Pobreza no Brasil no Período 1979-90. Revista Brasileira de Economia 49 (2): 277-294, abr./jun 1995.

IBGE, Pesquisa Nacional por Amostra de Domicilios - PNAD, Sintese de Indicadores 1993, 1996a.

IBGE, Pesquisa Nacional por Amostra de Domicilios - PNAD, Pesquisa Básica 1993, 1996b.

IBGE, Pesquisa Nacional por Amostra de Domicilios -PNAD, Síntese de Indicadores 1995, 1996c.

IBGE, Pesquisa Nacional por Amostra de Domicilios - PNAD, Pesquisa Básica 1995, 1996d.

JATOBÁ, J., A Dimensão da Pobreza Urbana e os Mercados de Trabalho: Iho: o Caso Brasileiro, 1970/83, em Mercado de Trabalho e Distribuição de Renda: uma Coletânea. Rio de Janeiro: IPEA/INPES, 1989.

KALECKI, M., Luta de Classe e Distribuição da Renda Nacional, em Crescimento e Ciclo das Economias Capitalistas. São Paulo: Hucitec, 1977.

KEYNES, J.M., A teoria geral do emprego, do juro e da moeda. São Paulo: Nova Cultural, 1985.

LACERDA, A.C. Distribuição de Renda no Brasil nos anos 80, em Revista de de Economia Política, v.14, n.3(55), julho/setembro/1994. 
LANGONI, Carlos G., Distribuição de Renda e Desenvolvimento Econômico no Brasil, Rio de Janeiro: Editora Expressão e Cultura, 1973.

MACEDO, Roberto B. M., Distribuição Funcional na Indústria de Transformamação. Tese de Livre-Docência, Faculdade de Economia e Administração da USP, 1977.

MARTINE, G. \& CARVALHO, J.A.M.de, Cenários Demográficos para o Século XXI e Algumas Implicações Sociais, em Planejamento e Políticas Públicas, n.2, pp. 61-92, dezembro de 1989.

MEDICl, A.C., Notas Interpretativas sobre a Variável Renda nos Censos Demográficos, em $A B E P$, Censos, Consensos, Contra-Sensos. III Seminário Metodológico dos Censos Demográficos, Ouro Preto, junho de 1984.

MEDICI, A.C., A mensuração da subjetividade: notas sobre a variável renda nas PNADs, em SAWYER, D.O. (org.), PNADs em foco - anos 80. Belo Horizonte: ABEP (Associação Brasileira de Estudos Populacionais).

MIGLIOLI, J., Acumulação de capital e demanda efetiva. São Paulo: T.A. Queiroz, Editor, Ltda, 1981

MURPHY, K.; SHLEIFER, A.; VISHNY, R., Industrialization and the Big Push, em Journal of Political Economy, 87:1003-25, 1989. 
NOVO SISTEMA DE CONTAS NACIONAIS - Metodologia e Resultados Provivisórios, Ano-Base 1980, em Textos para Discussão - v.1, n.10. Fundação IBGE, dezembro/1988.

PASTORE, J., Desigualdade e Mobilidade Social no Brasil. São Paulo: Queiroz: Ed.da Universidade de São Paulo, 1979.

PASTORE, J., O que está acontecendo com a mobilidade social no Brasil?, em VELLOSO, J.P.R. \& ALBUQUERQUE, R.C. de , (orgs.). Pobreza e Mobilidade Social. São Paulo: Livraria Nobel S.A., 1993

PESQUISA NACIONAL POR AMOSTRA DE DOMICÍLIOS -Volume 12-1988. Rio de Janeiro: IBGE, 1990.

PINTO, A., Distribuição de Renda na América Latina e Desenvolvimento. Rio de Janeiro: Zahar Editores, 1973.

PSACHAROPOULOS, G. \& NG, Y.C, Earnings and Education in Latin America ca, Working Papers, World Bank, Dezembro, 1992.

RAMOS, L.R.A., The Distribution of Earnings in Brazil: 1976-1985, Dissertação Ph.D., Berkeley: Depto. de Economia, Universidade da Califórnia, 1990.

REIS, J.G.A.; RODRIGUEZ, J.S.; BARROS, R.P.de, As desigualdades de Renda, em ALBUQUERQUE, R.C.de (coord.). O Brasil Social: Realidades, Desafios, Opções. Rio de Janeiro: IPEA, 1993 
SHORROCKS, A.F., Ranking Income Distributions, em Economica, v.50, v.50, pp.3-17, 1983.

SINGER, P. I., Dinâmica Populacional e Desenvolvimento. Tese de Livre Docência, Faculdade de Higiene e Saúde Pública - Departamento de Estatística da USP, 1970.

SINGER, P.I., Desenvolvimento e Repartição da Renda no Brasil, em TOLIPAN PAN e TINELLI (orgs.), A Controvérsia Sobre Distribuição de Renda e Desenvolvimento. Rio de Janeiro: Zahar Editores, 1975.

SINGER, P.I., Repartição da Renda - Pobres e Ricos Sob o Regime Militar. Rio de Janeiro: Jorge Zahar Editor, 1986

SMITH, Adam, A Riqueza das Nações. São Paulo: Série "Os Economistas", Editora Abril, 1983.

SOUZA, P.R. Emprego, Salários e Pobreza. São Paulo: Hucitec, 1980.

SUPLICY, E.M. \& BUARQUE, C., Renda Mínima- Experiências e o Debate no Brasil - Apresentação no $6^{\circ}$ Congresso Internacional da Rede Européia de Renda Básica. Brasília, 1996.

SUZIGAN, Wilson, Reestruturação Industrial e Competitividade nos Países Avançados e nos NICs Asiáticos: Lições Para o Brasil, em SUZIGAN et alii (orgs.). Reestruturação Industrial e Competitividade Internacional. São Paulo: SEADE, 1989. 
THUROW, Lester, Head to Head. New York: William Markow and Co., 1992.

URANI, André, Ajuste Macroeconômico e Flexibilidade do Mercado de Trabalho Iho no Brasil: 1981-95, em CAMARGO, J.M. (org.), Flexibilidade do Mercado de Trabalho no Brasil. Rio de Janeiro: Editora Fundação Getulio Vargas, 1996. 